
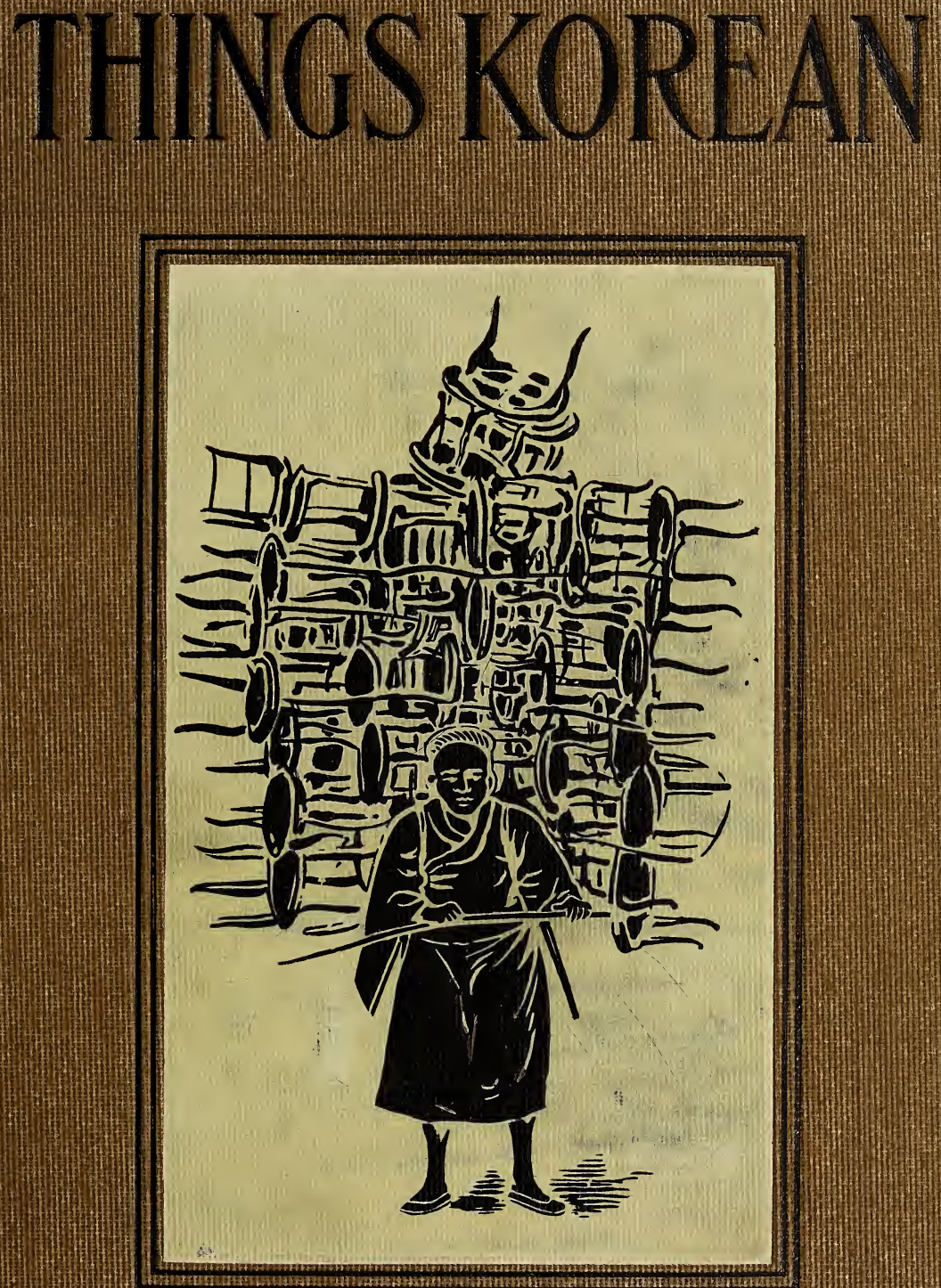

HORACE:N:ALLEN 
SMITHSONIAN

IMSTITUTION

$3 \% 4$ 


THINGS KOREAN 




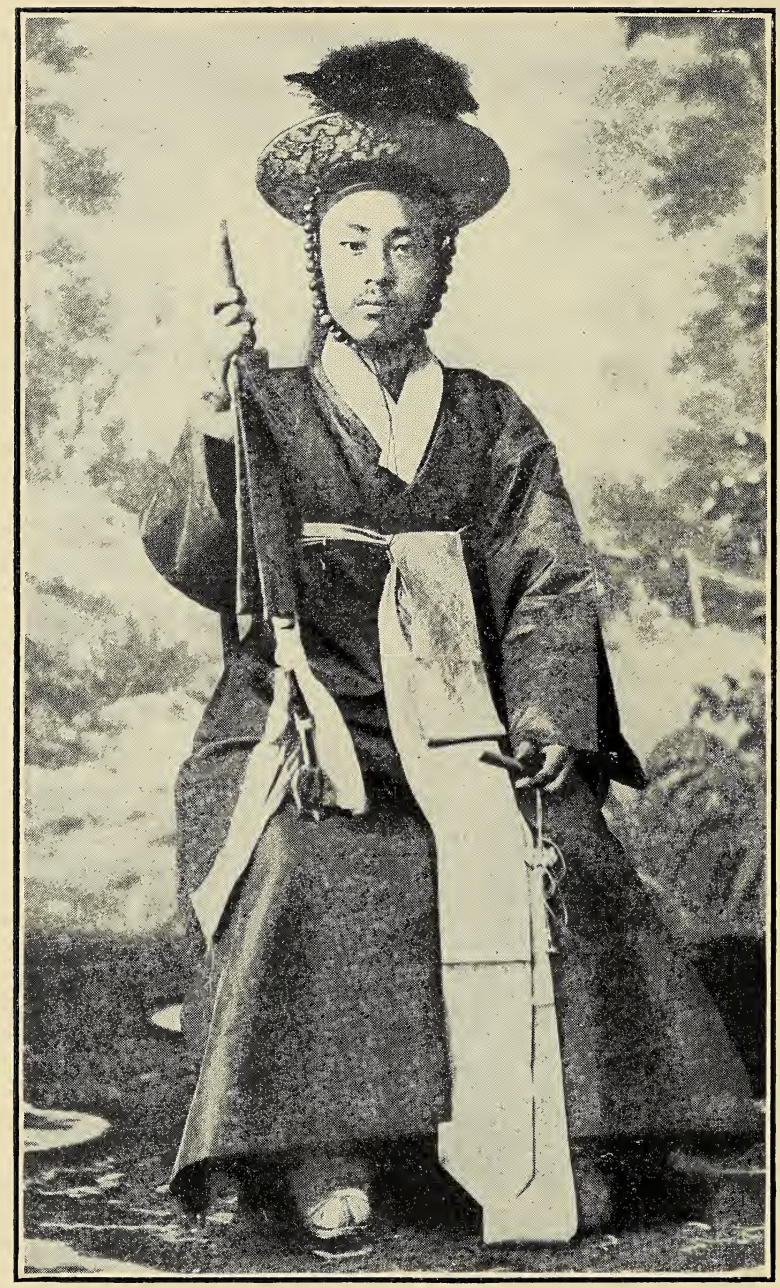

A KOREAN OFFICER OF THE OLD ARMY 


\title{
Things Korean
}

A Collection of Sketches and Anecdotes Missionary and Diplomatic

\author{
By \\ HORACE N. ALLEN, M. D. \\ Late Envoy Extraordinary and Minister Plenipoten- \\ tiary of the United States to Korea
}

\author{
ILLUSTRATED
}

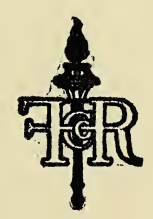

New York Chicago Toronto

Fleming H. Revell Company

LONDON AND EDINBURGH 


\section{Copyright, 1908, by \\ FLEMING H. REVELL COMPANY}

New York: 158 Fifth Avenue
Chicago: 80 Wabash Avenue
Toronto: 25 Richmond Street, W.
London: 21 Paternoster Square
Edinburgh: 100 Princes Street 
- $A 42$

TO

Mr WIFE 



\section{PREFACE}

THERE are incidents in the lives of each of us that are of more or less interest to others. Often some of these incidents are of general public interest.

'Twenty-two years' residence in China and Korea, including practically the whole period of the latter's diplomatic intercourse with the outside world, would seem to indicate an experience fruitful in incidents of general interest. This is my excuse for thrusting a new volume upon a public already burdened with books.

The writer spent a year in China as a medical missionary, three years in Korea in the same capacity, three years in the Korean service, and fifteen years in the diplomatic service of our own government, beginning as secretary of legation and ending as minister plenipotentiary.

The aim in writing this book has been to exclude the personal as much as possible, and to gather up the most interesting and illustrative bits descriptive of experiences had during this rather interesting period, together with entertaining accounts of the quaint people with whom these years were spent.

The poor Koreans are now in desperate straits and it has been suggested that this work be devoted to exposing their wrongs in an effort to turn public sentiment in their direction. Such a course does not 
seem to be advisable at this juncture,-rich as are the supplies of materials at hand. Opposition on their part seems at present to be unavailing if not suicidal; they can only make the best of existing conditions.

The sad feature of the case is that we deserted them in their time of need and ignored the solemn agreement we had entered into with them as an inducement for their abandoning the centuries-old position of exclusion and non-intercourse and emerging into the dazzling glare of treaty relations.

Our treaty with Korea of May 22, 1882, in its first article, makes the following promise :

" If other Powers deal unjustly or oppressively with either government, the other will exert their good offices on being informed of the case, to bring about an amicable arrangement, thus showing their friendly feeling."

We paid no heed to this solemn pledge at the critical time of the Portsmouth convention and must accept the odium attached to such violation of sacred covenants.

Present conditions, and our own mistakes, are sufficiently alluded to in the concluding chapters entitled American Commercial Intercourse ; Diplomatic Incidents, and Political Changes.

It is the wish of the writer that, while fully indicating his earnest sympathy with and kindly sentiments towards the Koreans, this little book shall be non-controversial, entertaining and instructive, and of such general interest that no single page may be 
found dull or tedious. Actual conditions in Korea at present as well as in China, are detailed in recent books, notably those by an English observer and writer of note, Mr. F. A. McKenzie, and by the well known American traveller and author, Thomas F. Millard.

Horace N. Allen.

Toledo, Ohio. 



\section{CONTENTS}

I. A Pioneer . . - . . - 15

II. The "Boy" and the Aмmah • . - 20

III. A New Year's Adventure and a Story of Economy • • • • • • 23

IV. An Oriental Bunco Game • . • . 28

V. Steamship Travel to and about the Far EAST • • • • • • • 31

VI. A Ramble in Country and Town • . 50

VII. A Seoul Night and a Revolution • • 68

VIII. Korea and the Koreans • • • • 73

IX. A Royal Funeral . . . . 152

X. A Mission to Washington . . . 159

XI. Missionary Comments . . . 167

XII. Medical Notes • . . . . 188

XIII. American Intercourse and Japan's IndebtedNESS TO KOREA • . • • • 209

XIV. American Commercial Intercourse • 215

XV. Consular and Diplomatic Incidents . . 223

XVI. Political Changes and Probabilities . 243 



\section{ILLUSTRATIONS}

Facing page

A Korean Officer of the Old Army . . . Title

Ponies with Pack Frames •

The Donkey, the Pride of the Lesser Official • 90

Peasants Hulling Rice • • • • • • 100

The Three-Man Shovel • • • • • 100

The Laundry and Mangle-“ Woman's Weapon” . 108

Three Men Sawing One Stick • • • • 108

Three Men Swinging •.$\quad \cdot \quad \cdot \quad \cdot \quad$. 150

BulL LoAdS OF WoOd for SALE • • • 150

A Royal Tomb • • • • • • • 172

One of the Priestly Figures . • • • . 172

A Stone Lantern • • . • . . . 172

A Street-side Temple in Seout • . . . 216

Seoul Officers of the American Firm Controlling the Electric Plant and Water-Works • . 216

A Group of Seovl Diplomatic Officials ․ 223 



\section{Things Korean}

I

\section{A PIONEER}

Among the adventurous spirits who seek fortune or excitement in newly opened lands, there are apt to be vigorous characters whose active careers have caused them to participate in many a thrilling adventure, some of which are highly humorous.

One such interesting pioneer in Korea was Captain Blank. Blank will serve as well as his real name, and the title which precedes it was sometimes given him because of the fact that he once served on a New Bedford whaler, which fact further indicates his Yankee birth and rearing.

In some manner Captain Blank got clear of his ship at Vladivostock, when he was about twenty years of age, and when everything was new and raw in that Siberian country, affording ample opportunity to Yankee enterprise and ingenuity. In time he became an extensive trader, buying skins of all kinds in exchange for general supplies. He married a Chinese woman and became the father of a family of mixed blood, including several stalwart sons who became his able assistants in the business. 
A Massacre.-One day on returning from a purchasing trip to Japan, he found his wife and sons murdered, and his warehouses looted and destroyed by a company of Chinese bandits.

The stricken old man went to see the Russian governor at Vladivostock, from whom he received hearty sympathy and an offer to do all in the power of the government to bring the miscreants to justice. The governor offered him a company of soldiers but this offer he declined and requested instead that he be allowed three or four volunteers. These were promptly furnished him and he evidently knew well how to select his men and was able to find kindred spirits.

This little band, well armed and supplied with abundant ammunition, disappeared into the wilds and were quite lost sight of for some time. After a few months, however, telegrams were received at Vladivostock from St. Petersburg, to the effect that the Peking government had complained that some one was killing hundreds of Chinese in the Amur country. On investigation it was found that the snow of the whole Vladivostock region was simply dotted with dead Chinamen. The captain and his volunteers had gone out for blood vengeance and had killed every Chinaman in sight or that they could find.

The governor called the American in and told him that, much as he regretted it, he would be obliged to arrest him, but that he would not issue the order for his arrest until noon of the next day. A steamer 
was leaving for Japan that evening and of course the old man took the hint and left with her.

Korea was just then opened and it was most natural that this adventurous pioneer should seek new fortunes in this fresh field. That is how we got our genial, honest, and only storekeeper, who was highly appreciated for his many good qualities and his general usefulness as well as for his interesting eccentricities. His vivid red and gray beard grew straight out around his ruddy face like a brilliant halo, making him much the most interesting of all of us foreigners to the natives, to whom all western foreigners were interesting in those early days, because of our-to them-absurd ways, our colouring, and our strange dress.

Before long an American minister came to reside in Seoul and the captain, with a keen sense of the proprieties and with not a little experience in official matters, from his long residence among the punctilious Russians, prepared to do the proper thing and make his formal call at the new legation.

False Teeth Cause Panic.-One hot July day, therefore, he donned a ruffled shirt, white tie, evening dress suit and silk hat, and mounted a pony to ride the long twenty-five miles across the country and its sand plains to the capitol, to make his call. At a little inn situated about half way on his journey, he stopped to eat the lunch he had strapped upon the back of the perspiring coolie who led his slow paced horse. Now these inns are arranged around a courtyard, across the rear of which stands the house 
proper with its tile roof and large open veranda-like room, off which are located the small sleeping rooms. The sides of the court are formed by the kitchens and servants' quarters, while across the front stands the long low building containing the stables, with a high roofed gate in the centre.

Seated on the veranda of the house, our traveller was quietly eating his lunch while his pony was being fed in the stable before him. One by one the natives flocked in on one pretense or another, to see the strange foreigner eat his stranger food. Finally all pretense was abandoned and the whole village, including the chance passers and their servants, crowded into the court to see the strange sight, until the space was simply packed with a quiet, perspiring crowd of sightseers.

The meal being finished the red bearded foreigner reached up and removed his false teeth for cleansing purposes. This was too much for his audience. It was a thing absolutely unheard of by them as yet and far beyond their comprehension, that a human being could thus take himself apart. With a scream of terror and the common call upon their mothers, "Ay goo Amonye," the mass struggled to get through the single gate and away from a being who could thus dismember himself, lest he call down upon them some dire fate or spell. Soon the gate was piled high with writhing forms each making all the noise possible, while the old man certainly enjoyed the unexpected effect of his casual action. From that time until his death the captain enjoyed even 


\section{A PIONEER}

more of the native attention than before, and he seemed able to get more from the coolies and pony men than could his competitors when they began to locate near him. 


\section{II}

THE “BOY” AND THE AMMAH

THE Ammah (pronounced Ahmah) is a most useful institution in the foreign communities of Asia. She is primarily the children's nurse, though she is just as often lady's maid, and she is not above doing duties that properly belong to the boy or valet, when he is missing.

The "Boy."-This boy, who may be a man of mature years, is another useful member of the household, and in addition to his general duties as butler, valet, waiter, and chambermaid, he is sometimes called upon to fill the place of the absent Ammah when my lady's waist needs buttoning in the back or shoes are to be laced or unlaced. He has even been known to shampoo and brush to silky softness the tresses of his mistress, and he quietly takes his place as an intimate member of the household whose interests he seems to have at heart, providing he is a good specimen of his class.

One lady acquaintance in diplomatic circles was horrified by the accidental blundering into her bath room of the boy, who had not fully completed arrangements for her bath and was bringing her fresh warm towels, not knowing that she was even then performing her ablutions. Backing hastily out in 
response to her shriek he called back in a pacifying tone of reassurance, "Never mind, missy, we all b'long one fambly."

The Ammah.-Our first experience with that useful creature, the Ammah, was about as amusing as it could well be. We had arrived from a severe Pacific voyage of twenty-five days to find that in Yokohama everything seemed topsyturvy. The boatmen in '83 dispensed with clothing very largely except for a large loin cloth; ashore the men served as horses, hauling loaded wagons, while others drew us in little carriages like overgrown perambulators, and we saw still other men sitting on the ground sawing boards from a log suspended above them, drawing the saw towards them in cutting.

Arrived at the hotel the obliging clerk asked if I did not want an Ammah for my wife who was ill. This was a new word but as he offered no explanation and as it sounded so like llama, I thought he was speaking of this mammalian. I therefore concluded that in this strange land where men served as horses llamas might be used in the place of cows, and as a milk diet was certainly indicated I acquiesced and asked if she could be kept on the place. On being assured that the hotel had regular accommodations for them I asked if some one would be furnished to do the milking.

After numerous explanations on both sides the Ammah was duly installed and she became a fixture, while no llama, not even a cow, directly furnished us our milk, which came out of a can. After twenty- 
five years' use of canned milk we prefer even now to use the evaporated and unsweetened article sold in tins, rather than run the risk of disease from using the fresh variety, while by so doing we avoid all trouble with the noisy and often delayed milkman who seems to be such a trial to some of our acquaintances in this land flowing with milk-if not with honey. 


\section{III}

\section{A NEW YEAR'S ADVENTURE AND A STORY OF ECONOMY}

A PART of the refrain of a recently popular song contained this promise :-

"If ye work all day ye'll have sugar in yer tay."

Few tea drinkers in America would consider this a luxury to strive for, sugar being considered a necessity by those who take it in their tea. There are people, however, to whom this bit of sweetness is considered as one of the compensations of hard labour and pinching economy.

Riding uneasily at anchor in a Korean harbour in the cold gray dawn of a stormy new year's morning, I listened to the cheerful tale of a woman's struggle for existence in a foreign land, and after twenty years, tea still tastes better with its regulation sugar, for knowing what a luxury it was to that one woman, who was so successful in earning a living for herself and her little children that she proudly boasted of the fact that they had tea every day-and sometimes they had sugar in it.

She was an Alsatian who had gone to Japan with her husband,-an artisan. He had died of typhoid 
leaving her with two small children. In time she had secured employment which paid her fifteen dollars (30 yen) per month. This was enough for a Japanese at that time, but it was a meagre pittance for the support of a western family in that foreign land.

She hired a room and they all slept in one bed. Everything purchased was in small quantities and for a definite purpose.

"We had rice and fish, and salad and bread, and sometimes we had butter on our bread," she told me.

"Every day we had tea and sometimes we had sugar in our tea." This in the land of tea and in a city where the air was fragrant almost to intoxication with the odour of tea from the great tea firing establishments.

"And every Sunday we would go to the hotel where the maitre d' hottel, my countryman, would let us have our dinner, with a glass of red wine, for a small price." How good those Sunday dinners must have tasted after their week's fast.

It was an interesting and pathetic story told that morning as we watched the gray dawn dimly light up the barren Korean hills peeping through their thin coating of snow.

A Chance Acquaintance.-We had not voluntarily sat up to exchange experiences. We were merely chance passengers on a very small Japanese steamer making the six days' trip from Kobe, via way ports, to Chemulpo, with no other white person on board aside from the Scotch captain whose quarters 
were forward in a house on deck. We had dropped anchor well off shore, in the extensive wind-swept harbour of Fusan on New Year's eve.

The cabins were below deck at the stern of the vessel and opened off the little salon. This salon was simply a passageway down the middle of the lower deck with the cabin doors opposite and the narrow dining table extending down the middle of the floor space.

A New Year's Celebration.-We had retired early, glad to exchange the gentle roll of the anchorage for the tempestuous seas of the Korean straits. We could hear occasional bits of song from the forecastle where our Japanese crew were beginning the celebration of the incoming year, for which purpose they had brought along a generous supply of saké. As midnight approached, however, the festivities increased and the copious libations began to tell. With the stroke of midnight and the advent of the new year, the crew, armed with pans and kettles from the galley, began to drum lustily and to march about the ship making a frightful din. Soon they came down the little companionway yelling like demons and beating their tom-toms as though all bedlam had broken loose. They entered the large cabin of my fellow passenger, and her shrieks and those of her children added to the general uproar. Jumping out as I was, thinking that some crime was being committed, I was eagerly hailed as a new recruit and our tormentors did what might be taken for a scalp dance around us while the poor woman on her knees 
called upon all the saints to protect her. We could not understand each other's language but we saw that the intoxicated revellers wanted us to drink with them and join in the festivities. They were just drunk enough to resent our reluctance and they became ugly at our refusal to join them. As matters seemed to be getting rather serious a steward and cabin-boy, who seemed to retain some degree of intelligence, finally interceded and, on some pretext, got the crowd up the companionway, the door of which we promptly barricaded; but the tears and fright of the foreign woman and her children seemed to stimulate them and they made many attempts to affect another entrance, so that we put on all our clothes and spent the remainder of the night pacifying the children and trying to keep warm during our vigil.

It was then that the poor woman confided to me the cheerful tale of her little economies and extravagances.

Bad weather compelled us to run in behind some islands and lay by another day after leaving Fusan. From this pitching unsteady anchorage the little straw-thatched huts of the natives on the lee hillside of the island, with the thin smoke curling above them, seemed actually inviting at our distance. They at least meant warmth and quiet, with no seasick qualms, though they did stand for an economy so rigid that the story of my fellow passenger seemed in comparison to be one of luxury; for in the case of the people in those weather-worn huts, while they 
might have fish, rice and salt, so far from the stimulating tea with "sometimes sugar," it was simply hot water with the tea entirely left out and sugar an unknown luxury. 


\section{IV}

\section{AN ORIENTAL BUNCO GAME}

THE Koreans are of a confiding nature. They are also over sanguine and inclined to espouse schemes that would not appeal to more sophisticated people.

One of my early native acquaintances had an experience in this line which is quite illustrative.

$\mathrm{He}$ and a few friends determined to prevent all the best business opportunities from going into the hands of foreigners in the early days, by occupying the field themselves. As the operation of steamships appealed to them as likely to be very remunerative and easy of control, they decided to establish a line of ships to connect their country with Japan, and thus keep this profitable undertaking from passing into outside hands.

They subscribed and paid in as capital stock a sum of money that loomed very large in their eyes and such as would buy a very creditable native junk. This sum, twelve hundred thousand cash, was equal to $\$ 1,200$ in Japanese money.

My friend had been in Japan and knew the language, therefore he was intrusted with the mission of going to one of the Japan ports to purchase their first steamship.

Arrived at Nagasaki he was soon made acquainted 28 
with a very polite and entertaining Japanese who showed him the sights of the city, wined and dined him, and for several days carefully avoided any serious talk relating to business.

After some days of this careful preliminary work, so characteristic of the Oriental, the Japanese began to urge upon the Korean the advisability of the latter's people undertaking the development of their country themselves lest foreigners usurp the field and drain the land of its resources.

This advice had great effect since it was right in line with the opinions held (and doubtless unintentionally expressed) by the Korean himself and bore directly upon the object of his mission. When it had been given ample time for patient assimilation, the new-found friend proceeded to suggest that steamships seemed to offer the best opportunities for such enterprise as he had suggested. This also met with hearty approval and it all seemed a strange coincidence to the Korean, since the advice of his genial friend was so entirely in line with the object of his own mission.

Further discussion disclosed the fact that the agreeable Japanese chanced to have a cousin who owned a fine large steamer which he might be prevailed upon to sell since the illness of his father compelled him to remain on shore and caused him to be in need of ready money. On enquiry being made it developed that this cousin would part with his ship and that he would sell it for $\$ 1,200$, which was just the amount the Korean had to pay. 
All necessary preliminaries having been arranged, the Japanese took his prospective purchaser on board one of the great Peninsular and Oriental ships that ply between England and Japan, and, passing him off as a prince who was making his first visit to a foreign ship, they were kindly received and shown all over the vessel, the Japanese acting as interpreter and putting into the mouth of either party the kind of words he wished him to utter.

The inspection having proved the vessel to be entirely satisfactory, the pair went ashore where a bill of sale was drawn up and signed by the reputed cousin. The money was paid over and the attentive Japanese left for the country.

The next day the Korean went on board and ordered the captain to sail for Chemulpo. It required the services of a policeman to rid the vessel of the importunate Korean, who never discovered the whereabouts of his genial friend and who never got back any of the capital stock of the first Korean steamship syndicate. 


\section{V}

\section{STEAMSHIP TRAVEL TO AND ABOUT THE FAR EAST}

Coral Islands.-On one of our twelve trans-Pacific voyages we had as a fellow passenger a senator of the United States; and for his benefit the ship steamed close to that wonderful chain of atolls or coral reefs, which extends our boundaries nearly eighteen hundred miles west of Hawaii. It was a sight never to be forgotten. Some of these formations were actually mere circular reefs with the spray dashing high on the windward side where the sharp, flinty, rocklike material effectually checked the continual onslaught of the waves, while inside the lagoon the water lay peacefully basking in the sun like a beautiful pale green crystal. Other reefs had accumulated sufficient animal and vegetable matter at some one place to support quite a little vegetation, which with its deep tropical green, against the lighter tint of the water, backed by the banks of white surf and coral sand, composed a general picture such as it is not often the lot of man to look upon.

These lagoons, lying like placid gems on the heaving breast of that great ocean, seemed so quiet and peaceful as to be just suited for havens of refuge for ships, especially as each had a more or less conveniently placed entrance. One such island is now used 
in connection with our trans-Pacific cable, but this appears to be the only one of the group where conditions are such as to permit of utilization. The quiet water in the lagoon is usually too shallow for ships and the low lying reefs are wind-swept and offer little protection, while their outer work is so dangerous that ships strive to give them a wide berth.

Rat Island.-We were told that one of these islands was so infested by rats that it was dangerous to land there. These rats had gotten ashore from some wreck and, subsisting on fish washed up on the coral sand, they had multiplied until no other living thing could exist in their midst. It is said further that the crew of a wrecked vessel were destroyed and eaten by these rats upon making their escape from the sea to this inhospitable land. This may have been but the " captain's yarn," however.

Summer Seas.-Sailing over these southern summer seas with not enough ship motion to prevent daily games of cricket and quoits, and with access to a great canvass swimming tank on the main deck, through which the sea water kept constantly flowing to a depth that was over one's head, we could quite agree with the Balboan nomenclature and willingly give to this vast expanse of tropical waters the title of pacific.

Atlantic travellers expect too much of the Pacific perhaps because of its name. It has its moods and some of them are ugly and spiteful. I once heard a Scotch captain exclaim that he would wish an enemy no worse fortune than to be consigned to 
the north Pacific route along the fog-swept Aleutian islands.

Bad Coast Weather.-This ocean seems to fret over the presence of large bodies of land. The sea seems always to behave itself worse as one nears the continent of America or Asia (including the Japanese islands). On one trip we left San Francisco on a Japanese liner when a gale was blowing of such force as to cause some damage on shore. Knowing what to expect we spent the time in stowing away our belongings and preparing for the fast approaching time when we would care more for the quiet of our bunks than for anything to be seen from the deck of the ship.

Some of the tourists to whom we suggested conditions that we thought likely soon to prevail declared that they intended to see the Golden Gate no matter what happened. They saw it. They also saw the staunch ship apparently stop in its course as it met a huge sea on the bar, shake its head for a moment as though indignant at such interference and then, like a horse taking the bit in its teeth, plunge madly into the seething race of rushing waters, where it kept on its course but with violent plunging and rearing.

It was pitiful to hear those good people as they abandoned the Golden Gate to the blanket of wet winds and dashed for their cabins, where trunks and valises met them chasing each other over the floor, so that it was dangerous trying to do more than make a rapid jump into a berth. One elderly couple near us dropped into their bunks as they were, and when later we got the stewardess to them in an at- 
tempt to relieve their loudly proclaimed misery, she found that the poor woman was too miserable to have her bonnet removed, so that she spent the night dressed as when she came on board. This weather continued with us much of the way to Honolulu after which the sea was like a mill-pond until the proximity of the Japan coast was reached.

A First Voyage.-Our first Pacific voyage was made on the old City of Peking, and it was one of the worst of these twelve trips as the last one was the best. On this first voyage in I 883 we spent twentyfive days out of sight of land. A full passenger list had compelled us to accept a cabin right in the stern of the vessel. It was large and more inviting than the others while the ship lay in dock, and we congratulated ourselves upon our good fortune, until we realized what it meant to try to be comfortable at the end of that tetering ship, where we got all the motion up and down side ways and corkscrew, as though we were sitting on the tail of some great water serpent that was lashing the elements in anger. Then every time the ship would poise on the crest of a mountain of water or fling its stern high in the air as it plunged down the other side, the screw would go whirling madly through the air right under our cabin, leading us to believe that everything in the machinery line had gone to smash, and afterwards as the stern sank and the propeller began churning up the waters again, while everything loose rushed sternwards, it seemed that we were surely headed for the bottom stern foremost. The whole passage was one 
long delirious nightmare from which relief seemed only temporary.

Three subsequent voyages were made on the old Oceanic for the reason that she had her cabins built up amidships. In fact she was an old Atlantic liner and was one of the first to have her cabins arranged in this manner at the hub instead of the circumference of the circle of motion. Both these old ships are now of the past and comment upon them is allowable.

Strange Japan.-Our anchorage in the harbour of Yokohama at the end of this first voyage was eventful. We had read much of the new Japan. We had met cultivated Japanese as students at American colleges.

Our anticipations were high. When we found our ship surrounded by scores of little sampans sculled about by men dressed only in a loin cloth, it seemed there must be some mistake. Had we not, in those tempestuous seas, missed our way and brought up at some south sea island? Surely this could not be the Japan of our fancy. Twenty-five years have worked great changes in the country, however, and regulations now compel the wearing of sufficient covering. These regulations are sometimes enforced in the wrong place as in the case of the young daughter of a diplomatic official residing in Tokio. The child was out riding with her little arms bare as were her legs from the top of her summer socks to her knees. She was arrested for violating the ordinance in regard to the wearing of clothing. 
An Eventful Voyage.-One fateful voyage we made in I889 on the Port Augusta, a tramp ship employed by The Canadian Pacific Railway while their present fine vessels were being built.

She was a long piratical looking craft that had only made two, unsatisfactory, trips on that route prior to the one when we were with her, which proved to be her last, as she was taken off the line as unsuitable. She had a small house built on the after deck for the entire passenger accommodation. This house besides furnishing a row of small cabins, held a little dining salon which was also writing and lounging-room. Two tables and a sideboard occupied most of the space, while there were divans along the sides which could be used when meals were not being served. The vessel had been built for the Australian trade and the dining salon was finished in marble, which may have been suitable for those waters but was decidedly out of place when we neared the Aleutian islands where the ever-present fog was condensed on the cool walls and the marbleized steel ceiling, so that the consequent dripping made everything seem moist and clammy inside the salon.

A Grewsome Sight._We had five hundred Chinese steerage passengers below decks, many of them in feeble health after a life of hardship and privation in America, and then on their way to their own loved land to die. As usual the steamship company had to contract to take them home, the schedule of charges definitely stating the price for a fresh corpse and for others of mature age down to dry bones. On the 
lines running out of San Francisco I had seen the bodies of Chinamen who had died on the voyage preserved by the injection of arsenic, but on this tramp steamer there was no such arrangement, though the tickets of the Chinese steerage bore an agreement to the effect that their bodies should be carried on to China in case they died at sea. The close air of the hold and the violent motion of the vessel were too much for some of the enfeebled old men and they began to die. The dead were placed in boats hanging on davits along the ship's side, one of which boats hung opposite our cabin, and whenever the ship rolled we would look into that ghastly boat-load directly in front of our cabin windows.

The weather was as bad as could be imagined. Gale succeeded gale and the seas were lashed to a fury that was appalling. It was cold and wet and too cloudy for an observation to ascertain our position. All cargo had been shut out from the 'tween decks to make room for the more profitable Chinese steerage, which made the ship, as the captain said, "like a bladder on the water," she was so light, for we had only a small cargo of flour. As a result of the pitching and tossing and the churning of the screw in the air, some part of the machinery broke down and we drifted for three days along the Aleutian islands.

St. Elmo's Fire.-I was asleep when this break occurred one night. It chanced to be a clear night, the rain had ceased and the stars were shining though the sea ran as high as ever. When aroused by my wife's alarm at the sudden quiet, I looked out 
of a port towards the forward part of the ship and to my amazement saw a ball of fire at every point. The yards were tipped with fire and the masts were topped with it; a ball of fire hung from every rope's end and studded every projection. On enquiry I learned that it was a fine display of St. Elmo's fire, an electrical disturbance sometimes seen and certainly one most startling to behold for the first time at the dead of night on a disabled ship drifting on such wild, tempestuous seas.

To make matters worse the first mate broke his leg and the captain, harassed by loss of sleep and anxiety over his inability to make schedule time with his ship, became afflicted with melancholia so that he had to be locked in his cabin.

A Mutiny.-While matters were in this dismal condition more Chinamen died and the boats being already full of bodies it was decided that the new corpses must go over the side. This caused a mutiny among the hundreds of survivors and an officer called me out, and on learning that I had a revolver, informed me of the trouble, and stated that as I had a family on board they would expect me to do my full duty. He placed me at the hatchway and told me not to let a Chinaman get on deck, but that if the steward came up first it would mean that all was satisfactory.

It was an anxious watch which ended by the grateful appearance of the steward. He had yielded and arranged to pickle the other bodies and stow them somewhere out of sight. The machinery was 
repaired, the captain recovered, the seas calmed down; we got a fresh supply of water by distillation, as that in the tanks had been churned about so as to have taken on a coffee colour from the rust washed off, and but for a serious shortage of food we would have considered ourselves in very good condition.

Short Rations.-We had only been provisioned for a passage of fourteen to sixteen days and as the voyage lasted twenty-five days, the last few of these found us subsisting largely on bread made from our small cargo of flour. One morning, however, we passengers sitting in our marble cabin and nursing ravenous appetites, saw to our amazement a fine boiled ham placed on the sideboard. We did not wait for the lunch hour or for any one to carve it, but getting some bread we made it into sandwiches and eagerly devoured it then and there. One of my little boys was so hungry that he growled like a dog as he ate his sandwich, seeming to fear some one might take it from him. It was fortunate we did not stand on ceremony, for the ham was the private property of the captain, and had been kept by him until this time of emergency when he seemed to think he had better eat it than take it on as the present it was intended to be.

We have made two later trips on the fine new ships of this line and found everything delightful except the foggy weather to be expected on that northern route.

What a delight it was after this stormy twenty-five days to awaken one crisp morning and look out upon 
great Fujiyama rearing its snow-clad peak high above us and seeming in the unusually clear air, to be near enough to reach in a short walk. How the surviving Chinese did sacrifice to the spirits of the water for their safe arrival in harbour! The bay was white with the paper money they threw overboard, while the decks were adorned with numbers of beautifully browned ducks and sucking pigs, which they bought ashore and had had roasted by their countrymen for the great sacrifice on board. They ate the sacrificial baked meats and gave the spirits of the water the imitation money, thus pleasing themselves and the spirits at the same time. They undoubtedly needed the meats more than did the spirits.

One memorable trip over this route was made on the great cargo ship Minnesota, with the Japanese Peace Commission en route to Portsmouth, as fellow passengers. This vessel is so large that she seems to experience no appreciahle effect from the motion of the sea other than the gentle swell of the deeper water. Cabin windows take the place of port-holes since the passenger accommodations are in a large house high up on deck a little to the forward part of the ship. One item of her freight on the way over from America was said to have been fifty-seven railway locomotives. Naturally the racks were never placed on the tables and flowers stood in glasses on the window sills as safely as they would in a residence on shore.

Chinese Stewards.-One comfort of this Pacific travel is the Chinese cabin-boy. Only those accus- 
tomed to his ministrations can realize the excellence of a Chinese servant. Quiet, attentive, and always on hand, he is the ideal attendant for a sea trip as he is also for a habitation on land.

A Tip.-On one such trip we had as a fellow passenger a missionary and his family from the interior of China. The wife and children were ill and required a great deal of attention, which was cheerfully given by the cabin-boy to whose care that particular stateroom fell. When the voyage was ended the missionary explained to the servant that he desired to do something to reward him for his faithfulness. The "boy" took on a willingly receptive manner, which soon disappeared, however, when he realized that the expected reward was nothing but a basket of empty medicine bottles. The donor had lived long in the heart of China where bottles have a value and are prized as a servant's perquisite; he seemed to forget that the market in San Francisco might not be so good.

Tips are now about the same as on the Atlantic. The cabin-boy, table-boy and stewardess, where there is a lady, should be given five yen $(\$ 2.50)$ for each person, the bath-boy, boots, and others being tipped in proportion to the services rendered. Considering the length of the voyage this is cheaper than the rates that prevail on the Atlantic.

Free Baths.-On the trip over to Japan once, we had a young man making his first trip at sea. He was going out as a missionary and his clothes were the regulation weight worn in college. As we 
neared the tropics he became more and more uncomfortable and finally decided that however extravagant he must have a bath. He mustered up courage and enquired of the rather gruff purser the price of a bath. On learning that they were free and to be had on demand, he seemed to spend much of the rest of the voyage in making up for the baths he had lost during the earlier part.

A Typhoon.-Bad as is the Pacific at times it is greatly to be preferred to the more shallow and confined waters of China and Japan in typhoon season.

A typhoon is a circular storm akin to the cyclone. Should a ship get caught in the centre of this storm she would probably perish, but in these days warnings are given of the approach of these storms and the vessels try to seek safety by getting out of the path of greatest danger.

In $1884 \mathrm{I}$ was in the long narrow harbour of Nagasaki on board the Nanzing, en route from Shanghai to Chemulpo. A typhoon was reported coming up the coast and our Scotch captain, not wishing to be caught, as he described it, "like a rat in a hole," steamed out for the open water. We caught the storm in the narrow straits of Korea and our ship suffered considerable damage. It took thirty-six hours to make the thirteen hours' run to Fusan. The captain was lashed to the bridge and the two other passengers and myself stuck to our bunks though our cabins were awash with the frequent seas we shipped.

My furniture was on board and I had been told we 
had little other cargo. Somehow in my delirium, when the screw went grinding about out of water, I got the idea that it was a new brass and iron bedstead we had bought in Shanghai and of which we were quite proud. Just how or why the bed had been set up on its castors I did not stop to consider, but it seemed as the screw went rolling about making its horrible noise, that it was that beautiful brass bedstead rolling over the empty hold.

Returning a month later for my family, in passing through Nagasaki, I saw the awful wreckage wrought by the typhoon which swept up that long narrow inlet. Great ships which we had seen staunchly riding at anchor were at that time well up on the beach, broken and apparently worthless. One such I remember was a fine sailing ship, The Western Belle, which when we sailed out of the harbour, was flying the homeward pennant after having discharged her cargo of lumber, reloaded, and been cleaned and painted for the homeward trip. On this return she was seen on her side, a very dishevelled belle lying well up on the beach, apparently fit for nothing but junk.

Thousands of natives were said to have lost their lives in this storm and we had occasion to thank our intrepid captain for his sagacity and courage in getting out where he would have a chance to fight.

War-ship Travel._On several occasions we made this trip from Japan to Korea on one of our naval vessels sent for the purpose, and it seemed very odd to be consulted as to when we would like to start, and to have the ship slow down or increase her speed 
in order that we might arrive at a suitable time. This was the perfection of sea travel except that our presence crowded and inconvenienced the officers, and caused the commander to give up his comfortable cabin for our use.

China Coast Travel.-Travel on the British coasting vessels and river ships in the early days was delightful. Every one was supposed to bring along his personal servant, and to the luxuries furnished by the ship would be added the fresh fruit and delicacies brought on board by these well-to-do and hospitable foreign residents.

On a trip up the Yangtze, in I883, we had a great bedroom with a four-post double bed and mosquito curtains. It was like an admiral's quarters. Foreign passengers were few and they were comfortably quartered on the forward part of the ship, away from the odours of the densely packed Chinese steerage which occupied the after part. These people were stowed away on shelves one above another and seemed happy, for a Chinaman dearly loves the companionship of his kind. They were much given to travel and naturally contributed largely to the profits of the owners of the vessels.

Pirates.-One little reminder that there might be another side to this picture of comfort framed by our luxurious quarters, was the presence of a row of muskets that stood in a rack around the mast where it passed up through the main salon. It was not uncommon for pirates to attack these ships, particularly on the southern waters. Sometimes a band of them would 
take passage among the unsuspecting native steerage passengers, and at the chosen time they would arise and kill off the crew, beach and loot the vessel and make their escape.

Saigon.-Once we went up the winding river to the quaint city of the French possessions, Saigon, which is a miniature Paris on the Anamese flats. Sometimes the French liner would brush the trees with her stern while her bowsprit would extend over the other bank of the stream in making a sharp turn. We were entertained here by one of the wealthy residents of Saigon, and were surprised at the formal dinner to see a Siamese cat mount the table as though some such feat were expected of her. She walked daintily about smelling of things, but never interfering with anything. She was so well bred that she would only eat from her own dish, and must have her regular food prepared of chicken and rice. It would have been a distressing experience for a Korean, since Koreans, as elsewhere explained, faint at the sight of a cat at table.

In Saigon the restaurants and hotels have their dining-rooms located under awnings on the pavement, or on a veranda in front of the house, where one may enjoy the cool air of the morning or evening and have the pleasure of seeing the richly-dressed passers-by. The hot midday is given up for sleeping and as we did not know of this we came very near missing our ship as we could get no carriage and only secured the services of some Anamese jinricksha men with great difficulty. 
Shanghai and Hongkong.-While Shanghai is most impressive for its volume of business and broad level roads lined with massive buildings, it is flat and low lying, whereas Hongkong is built upon the hillsides, with only a strip of level ground along the water front. It therefore shows up splendidly, every house seeming to stand out in its luxuriant gardens. It is backed by a high hill or mountain, called the Peak, which now has a cog railway giving access to the homes and pleasure resorts at the summit, from which one gets a wonderful view of land-locked water and hill. The public gardens here and at Saigon and Singapore are well worthy of a visit.

Russian Ships.-Travel over the China and Japan seas is now done largely in Japanese vessels, but prior to the recent war between Japan and Russia we made several trips across the Yellow Sea on the Russian ships. Although some of these were large and comfortable they did not seem to be as well kept up as did the old time British vessels. We encountered some strange customs on board these Russian steamers, one being the separation of the sexes. My wife was put in a cabin on one side of the ship while I was assigned one on the opposite side. This was inconvenient as our belongings were not packed separately and besides, we preferred to share a cabin. It took a great deal of persuasion and a reference to the captain before we could arrange matters satisfactorily. In fact we had to get the consent of all the other women passengers before the matter could be arranged to suit us. 
Fire Water-On another of these ships we sat down to one of those excellent meals for which the Russians are justly famed. We had a stack of plates before us, and as one course was finished the top plate would be removed, leaving a clean one for the next course. My companion desiring a drink, reached for a caraffe in front of her stack of plates and poured out what she supposed was a glass of water. I noticed that the captain seemed surprised and concluded that he wondered at her taking water with no corrective in it. However as she seemed about to drink it he called loudly for the steward, who spoke English, at the same time using a vigorous sign language which halted the goblet before the beverage had been tasted. We were then informed that the clear fluid she had taken for water was vodka, the Russian drink of the strength of brandy.

The stack of plates on these Russian tables reminded me of the early days when the British coasting vessels served food from double decked plates with hot water in the space between the top and bottom, held in by a cork in the rim. This arrangement kept the food hot while bringing it from the galley or the serving table.

A Tourist Route.-Formerly it was a four or six days' trip from Yokohama or Kobe to Chemulpo. Now all that is changed. Instead of the stuffy little Japanese coast vessels that made this trip the most objectionable part of the journey from America to Korea, one may go by rail from Tokio or Yokohama to Seoul or Chemulpo, with only a night's experience 
on the water in crossing the Korea straits from Shimonoseki to Fusan on a fine large and comfortable steamer.

From Fusan one makes the journey to Seoul in a day over a standard gauge railway with cars either of American build or patterned after the American cars. A creditable meal is served in the dining car while the train speeds past ancient ruined temples perched on distant mountainsides, past hamlets picturesque enough at a distance, with every now and then a glimpse of some white clad native squatting on an elevation and stolidly smoking his long pipe, while gazing with apparent indifference at the remarkable foreign innovation that has robbed his land of its quiet seclusion, and caused the ill-kept roads to grow up with grass and weeds for lack of the old time travel.

From Chemulpo the tourist may embark on a twenty-hour journey across the Yellow Sea to Chefoo, Port Arthur, or Dalny, from which last named place the Russian built road connects with Europe. Or the traveller may go on by rail to Peking and thence south to Hangkow by the newly built Chinese railway, whence the ride down the Yangtse River to Shanghai will be a great delight.

It is a delightful journey, at the proper season, to go from America to Japan, then to Korea and across to Dalny, thence on to Peking and down to Shanghai by way of Hangkow and the river, then on by way of Hongkong, Singapore, Columbo and the Suez canal. But the pleasantest trip we ever made was by way of the Russian railway from Dalny through 
Manchuria and Siberia to St. Petersburg and on. This may now be done from Seoul by way of the new Japanese railway to the northern border of Korea, where a construction railway, which now serves to connect this road with the Russian built Manchurian road, will soon give place to one suitable for travel, so that the traveller may go from Yokohama or Tokio to all parts of Europe, with no sea travel except the short ferry across the Korean straits from Shimonoseki to Fusan. 


\section{A RAMBLE IN COUNTRY AND TOWN}

As seen from the deck of a ship the Korean coast looks bleak, barren, and generally uninviting. This is just as the natives desired it should look, for when they were in fact as well as in name, the Hermit Nation, they permitted no intercourse with the outside world except at two places, and even there under strict restrictions. In order not to tempt outsiders to desire to land and enter their country, the peasants were permitted to cut off all trees and shrubbery from the hillsides facing the sea, thus giving the coast lands a dreary and cheerless appearance not likely to tempt the few passers to care to penetrate into such a forbidding looking land.

Just persevere, however, and cross that bold ridge beyond yonder desolate stretch of mud flat, and the chances are that quite a different impression will be gained, for it probably shields a wooded hillside and comfortable hamlet from the wintry blasts off the sea, while a rich rice plain may occupy a far-reaching valley, terraced up with little grassy dykes, as high on the hillside as compatible with obtaining a supply of water for irrigation. The usual brook to be found in a valley is sometimes tapped for this purpose, well up on the higher ground, and the water 
is then led to the uplying paddy fields, from which it is let off upon those lower down. Sometimes this requires the construction of a long irrigating ditch, such as may be seen in the environs of Seoul; for the successful culture of rice indicates the possession and employment of no small degree of skill and diligence in the business of farming.

The Koreans are essentially an agricultural people and they are capable farmers, though by no means as successful as are the diligent Chinese, who rent ground of the Koreans and then succeed in making a living from selling farm products to the natives themselves.

Bulky farm produce will not bear distant shipment except by boat, for roads in Korea are apt to be mere bridle-paths, since wheeled vehicles are rare and land transportation is mostly by pack,-_bulls, ponies, men and women making up the pack-trains. There are of course some main roads which a little attention would convert into creditable thoroughfares, but these are few and far between.

Bridges and Floods.-Travellers are always amused to find that in Korea the bridges are taken away just when most needed, in order to keep them from being carried off by the floods. But bridges in this land are really only meant for fine weather, which means about ten months in the year. They are temporary structures which are removed on the approach of the rainy season, otherwise they would be swept away. Every one expects to be inconvenienced during the rainy season, and so desirable is it to have a generous 
downpour, that no one is likely to complain about a little inconvenient wetting. At such times boats are usually to be found for hire at a bridge site, or if the water is shallow and crossed by stepping-stones ordinarily, there will be men within call who will leave their work and carry the pedestrian over for a small compensation. Usually the people who are not mounted will expect to wade.

Country Aristocracy.-Occasionally in journeying along one of these winding paths one passes the somewhat pretentious country place of one of the noble class, with its adjacent grove of trees sheltering the burial site of the family ancestors, and incidentally beautifying a whole hill or mountainside.

An air of prosperity and contentment seems to pervade the hamlet of the retainers of this dignitary who stands between them and the rapacious officials from the capital. It is a pretty picture of a sort of feudal condition, and the children of this lord show in their aristocratic bearing the pride of birth which links them to the comparatively few families of distinction in the land, most of whom seem to know, or to be related to, one another.

Korea is a small and insignificant land but she represents an ancient civilization which made her the schoolmaster of Japan. It is not surprising that pride of birth and descent should have become one of the marked traits of these simple-minded people, shut up in their hermit land for so many centuries, quite content with what could be produced within their own borders and only asking to be left alone in 
their seclusion. This condition could not but inspire an exaggerated idea of the importance of their own land and all that pertained to it, especially as to the attributes of their ruling classes.

The Sky-line.-But to return to the country itself. Eastward from the deck of a ship at Chemulpo may be seen a peaked and turreted sky-line, like the ridge of a gabled and towered house, looming well above the place where Seoul is pointed out to be. With a glass one may see a little white dot in a depression between two of the highest of these peaks. This dot is the opening in one of the gates of the ancient mountain fortress known as Poukhan. It was with the capture of this place of refuge that the Manchus secured possession of the royal women of Korea in 1637, and thus compelled the ruler to capitulate. He was safe in still another fortress. So plucky was this defense that the Manchus, who had already conquered China (which is still in their control) did not compel the men of Korea to wear the queue or the women to bind their feet, contenting themselves with the exaction of a mere nominal expression of vassalage to the Manchus as their sovereign lords. This claim persisted until it was finally exploded by the Japanese as the result of their successful war with China in I894.

A Mountain Fastness.-From Seoul it is but a day's pleasant journey to and from this historic place of refuge. Though there are other places of interest that might be quite as pleasing, perhaps a short description of this and the road leading to it may be 
as illustrative as a description of any locality in the environs of Seoul.

One road to this resort leads directly up to the gate between the peaks, before mentioned, and involves a rather stiff climb. This is a good way for the return, but in going it is better to fare farther and pass around the mountain and in through a more gradual incline.

A good carriage road leads from the West Gate of Seoul through two passes in an outlying spur of the mountain ridge which forms a part of the background for Seoul. Just off this road, over the first pass, lies a well watered valley surrounded by wooded mountainsides, known as the valley of the lilies. It is of course a burial reservation, the whole valley and in fact all the land in sight, being kept for the post mortem home of the family of a prince.

Lilies.-Formerly the ground in this locality was literally covered with wild lilies of the valley, which gave the place its name with us Western foreigners. The blossoms were luxuriant and perfect, and it was a shame to destroy them, but native boys finding we would buy them, took to gathering them in such a careless manner that the plants were practically destroyed. Patches of these delicate lilies may frequently be found in Korea. I have eaten my lunch sitting by a great bed of them that seemed to extend for acres over the hillside. In fact it is a land of flowers, some of which are very fragrant, and there seems to be some of them in blossom from snow till snow. 
The rapid mountain torrents that sweep the hillsides during the rainy season bring down vast quantities of sand-like, disintegrated granite, which is deposited over quite a plain at times, destroying vegetation and producing a miniature desert, indicating the urgent need of some forestry rules and regulations. Crossing such a sand plain the route to Poukhan leads off to the right through a grove of old pines which gracefully arch over the road in a delightfully cool and inviting manner. Grassy banks, sloping up to well-kept graves, make a comfortable resting place and indicate the reason for the existence of this wellkept grove of ancient trees. Somebody's ancestors have this beauty spot reserved for their use, and their descendants keep it in order.

Picturesque Surroundings.-Towards the west extends a wide plain with quite a growth of pine and oak backed by a high ridge, over which in the evening the declining sun spreads a colouring of rare tints such as is seldom to be seen elsewhere. Even the commonest Korean pony boy as he conducts his train of two or three ponies through these picturesque glades on his return from packing fuel to the city, will break into song, though he may not realize that it is the quiet beauty of the scene that so affects him. His song is apt to begin,-

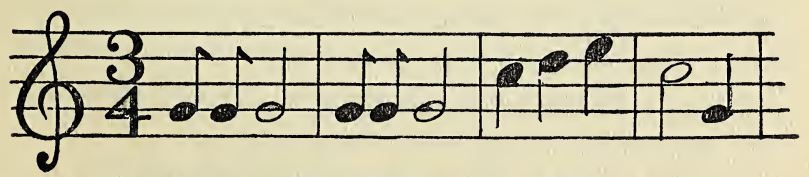

Ah rey rong, ah rey rong, ah rah rey oh-o, 
and very musical it is as heard, unseen, through the trees.

In the early summer these hillsides resound with the cuckoo's call, and frequently I have been suddenly arrested by the song of a lark as he would shoot straight into the upper air and, fluttering there, pour forth a flood of melody as though his very heart would burst with the joy of his surroundings. Even the chair coolies would stop talking to listen to the song.

Great white or gray herons would rise lazily from the rice-fields, or maybe a white stork would go sailing majestically away with but an occasional flap of its wings, as though flying to it were but coasting down aerial hills. Magpies there will be in plenty, and they will follow and scold us in a sociable way.

Soon our route will be over a mere winding mountain path, taking us ever higher and higher along a bubbling stream of sparkling water. Farmers eking out a living from a patch of land reclaimed from the stony mountainside for the culture of cotton, beans or peppers, will stop to watch us pass, glad of the little diversion this chance meeting brings into their lives. Possibly it will be a band of men and women in mud and water to or above their knees, planting or working their rice, in which case we will receive little attention aside from some joke sprung by the jester of the party, for such work as rice planting is too engrossing to allow of sightseeing.

In the autumn the straw thatched huts of these 
toilers will take on a brilliant, harvest holiday hue, from the heavy layer of crimson peppers placed there to dry in the sun. For a rice diet requires the use of much condiment in order that the over-distended stomach may be spurred on to duty. Peppers, therefore, enter largely into the Korean dietary.

A Petty Aristocrat.-On our left we pass a hamlet of poor but comfortable straw thatched houses, each with its surrounding wall of earth or brush for the seclusion of the women. Rising imposingly above these straw roofs is one of tile, covering a more pretentious building situated on higher ground. From the compound gate of this establishment may be seen emerging the petty official controlling this particular district. Great round, slightly smoked eye-glasses proclaim his scholarly attainments; jade ornaments on his head band announce him to be of official rank, as does the fact that his gown is split up the back to the girdle and swings aside in the breeze, while the gowns of his peasant neighbours are continuous. His stride is the very essence of composed superiority, swaying from side to side as should be the case with one so accustomed to sitting crosslegged and pondering over the printed page.

What dignity enshrouds this little lord as. he makes his stately progress over his tiny domain, bearing a long stemmed pipe which he cannot hope to light himself because of the shortness of his arms in comparison to the length of the stem, necessitating a pipe bearer to do the lighting. He represents and embodies in himself the majesty of the law and he it is 
to whom all questions are referred for elucidation or judgment.

$\mathrm{He}$ is as proud and as conscious of his power and dignity, and is as satisfied with the little world encircled by yonder hills and mountains, as is the great dog by his side, with bushy tail curled over his back and eye alert for any trespass on the part of his particular subjects-the curs of the neighbourhood. The latter dart through the dog holes cut in the house doors, through which they discreetly eye the big fellow as he passes along with his master, to whom the villagers pay respectful obeisance and seem grateful for a condescending word in return.

These simple-minded people know there is land beyond those hills; that there is other land even beyond the eastern seas. They may have been to the capital and seen the strange men from these distant lands, who, having heard of the greatness of Korea have travelled many days and nights over those seas from less favoured lands, to share the joys of life in the land of Chosen.

They have their quarrels and their sorrows, they also have their simple joys. They have a warm place in which to sleep; they are not hungry, and they have their ever-present pipe with an occasional cup of wine. They have contentment.

What a pity it seems that our so-called civilization must enter and disturb this dream.

Formerly an ambitious youth could study and acquire the written character and a knowledge of the classics, after which he could enter the state ex- 
aminations and on passing them, secure promotion to the greatly desired official class. Not even the post of prime minister was beyond his reach. What more could be desired?

It is not surprising that they should now resent being absorbed by a race they have long despised, the history of whose intercourse with their land is written in blood, and whose subjects care not for ancient Korean customs and but little for native rights, while respect for age and rank is quite neglected.

Poor Koreans, you have waited too long. Perhaps had your land been tossed and riven by earthquakes and volcanoes you might have been shaken out of your contented sleep. But while you slept and dreamed and cared for naught but to be let alone, your ancient enemy has been busy learning the arts of those strange folk you see even now, wending their way up your ancient path to yon fortress o your ancestral kings. Having learned these arts she has even vanquished one of her teachers, and you, once a teacher but now a decrepit old ex-officio, what can you hope for when your land is wanted by your energetic erstwhile pupil. The sleep is o'er, the dream is done and now comes the struggle for existence amidst competition keen and sharp.

Winding about through hamlets, groves, cultivated fields and over wild rocky hillsides, our road has been paralleled by a ridge, surmounted by a wall of masonry, connecting the city wall with the fortress proper. This was built in ancient times for protection against incursions along the route from China, for a 
part of our road was over the main highway from Seoul to Peking. This wall served its purpose in the days before the use of firearms. In the low lying part of the fortress, also protected by a high wall, there is a great gate through which we enter to the mountain fastness proper.

The landscape changes little on passing through this gate and we go on ever higher, following the brook which becomes more boisterous, boiling and foaming around great masses of rock that have fallen and obstructed but have not been able to stop its course. Beautiful clear basins of water have thus been formed, just the place apparently for trout and most inviting for a plunge on a hot day.

Pleasure Pavilions.-Little tile roofed pleasure pavilions are built out over this brook, with open sides protected by carved railings of wood, and affording delightful resting places where in the springtime one may feast on the view of vast hillsides covered with the pink fluff of the densely growing wild azalea.

The presence of these pavilions indicates the nature-loving instincts of the natives who erected them, and lest their memory be forgotten they have caused to be erected near by, massive stone tablets bearing their names and sometimes a verse of poetry commemorative of the beauties of the surroundings.

In the heart of the depression higher up, surrounded by lofty peaks rising still higher, nestles a group of temple buildings where foreigners sometimes spend the summer, while on higher elevations, 
seemingly hanging to the mountainside, are clumps of large buildings used as palaces on occasions when royalty was obliged to flee for refuge to this place.

When I first went to Korea the use of these mountain fastnesses had not been abandoned owing to the introduction of modern ideas and methods, in fact one of these places of refuge was actually used in I 884 for the succour of an American naval officer who was travelling in the interior.

In preparation for any emergency these places were kept provisioned for a siege, while being well watered they could support some cattle and produce quite a crop of vegetables.

A Place of Refuge.-When necessary the royal refugees would be borne over a private way from the city along a ridge of granite sand up the steep sides of the outer aspect of the resort and through one of the gates away up in the cloud line. Soldiers with picks would soon demolish the ridge so that pursuit, such as it was in the olden time, would be difficult, and men stationed on the battlemented walls above would be able to guard the place with comparative security.

From one of these gates, on a clear day, Chemulpo may be seen with a glass, twenty-five miles distant by road, while the great Han River lies between like a ribbon of silver winding in and out for forty miles between hill and mountain, before meeting oblivion in the Yellow Sea that stretches off to the horizon.

Just outside and to the right of this gate, which is 
the little dot seen from Chemulpo, there hangs a small temple on the face of the cliffs in front of a long cave with a wonderful spring of water at its farther end. Water seems to be the one thing most to be desired after climbing to this place and such soft, cool, limpid water as that which bubbles from this spring is seldom met with. It is supposed to possess medicinal qualities which tempts people to make the ascent and stop at the temple with its shelves containing hundreds, if not thousands, of little buddhas. Certainly the exercise and water, together with the air and view are enough to improve one's physical condition even if disease is not cured thereby.

On the descent from this temple the grooms hold the horses by the tail rather than by the bridle and the trip home may be done in one-third the time taken for the ascent. Even high up among the rocks where it would seem to be accessible only to a bird, natives may be seen gathering fuel among the stunted little bushes growing there.

No Seclusion.-In Asia it seems difficult to get away from people. Go out into the wildest place, climb a ridge and crawl up a gully, then just as you feel that at last you are alone and may throw up your hat and hurrah all to yourself, you are likely to look up and catch the stolid eyes of a native gazing upon you as though wondering what sort of fire-wood you are looking for. This is apt to get on one's nerves at times, and it is a vastly more serious matter in densely populated China, where one may get out-ofdoor privacy only by accident and then not often. 
Paper Making.-After climbing down for some time habitations begin to appear, the first being those of the paper makers working out-of-doors making a paper that is like parchment, and very greatly prized in China and Japan, for use in writing state documents. They use the bark of the mulberry chiefly, and macerate it in spring water with wood ashes until it is a gray mass of pulp; they then spread it on little bamboo mats like window screens, layer upon layer. After the pile has drained sufficiently, the layers are separated and dried in the sun and later ironed smooth. Like the other manufactures of the country, this is done at home by the people whose ancestors spent their lives doing the same until the various movements are like second nature to them.

Another bubbling brook accompanies us as we go down, with its cool pools and picturesque pavilions placed where the finest views are to be had. Lower down the hillsides are terraced and set out to peach, apricot and pear trees, hedged in with rows of cherry bushes, with here and there a fine wax-like persimmon-tree, or it may be an English walnut.

Persimmons.-In the springtime it is quite the thing to go out to these fruit groves and see the blossoms, though the autumn also has its attractions when the frosts have dropped the leaves and the great red persimmons are still hanging. This is the grafted persimmon such as is now grown in Florida and California from cuttings sent from Korea and Japan. It is a delicious fruit to eat fresh, while it is also pre- 
served after the manner of figs and if well done, it is quite as good as a fig. In appearance it resembles a large red tomato, when ripe.

Seoul.-Entering Seoul by its highest gate, well up in a depression in the mountain ridge, a long white road is seen winding down into the city, which is sufficiently distant to present a very attractive appearance with its abundance of foliage and its masses of tiled or weathered thatch roofs. The sombre tints of the mass of low lying native houses are relieved by the brightly-painted work of the lofty palace buildings, while the buildings of the foreign legations and the French cathedral, capping eminences, stand out strikingly and relieve the general monotony.

In the streets themselves there is little that is attractive aside from the kaleidoscopic effect of the colouring displayed in the gowns of the men, women, and children. The shops are mere little booths in front of the dwelling or work-room. There are no sidewalks, and ponies, bulls, carts, street-cars, and people all mingle together in the sandy dust or thin mud.

A Street.-To a Korean a street is but a way from place to place. It has heretofore seemed to need no particular attention since the rains wash away the filth, and at any rate, any one of consequence will of course be borne in a chair or on a saddle, if necessity compels him to move abroad, and now that the Americans have brought the street-car, even the coolies may ride.

According to old custom it would not be wise to 
beautify the exterior or street face of the buildings since that would simply tempt thieves to the property of the man so prosperous as to thus publicly proclaim his prosperity. Therefore a dilapidated row of buildings along the street, some of them propped up to prevent the heavy tiled roof from falling, may enclose a set of very nice houses with large park-like grounds studded with lotus ponds, clumps of large trees, shrubs and grassy lawns.

Artistic Compounds.-I have in mind while writing this, one such compound that I have often visited and seen its wealth of beautiful carved wood indoors, and carved, weather-worn stone outside,-all reached through a dirty alley leading off a dirtier street.

One of these better class establishments is well worth a visit. The great high roofed gate with keeper's lodge alongside, opens into a courtyard surrounded by the stables. In this court the sedan chair of a lesser official is put down while the occupant will pass through a little side door in the great inner gate. Should he be of sufficient importance the great gate itself will be opened for him, and if he is of still more importance the gate will be opened to the accompaniment of sundry loud calls, and a vast amount of squeaking of the hinges, as he is actually borne right through in his chair. In the case of an intimate of still greater rank and importance the chair and its occupant are borne into still another court, this time a large ornamental one into which the host's apartments open and beyond which 
are the quarters of the women with their pretty flower gardens, where these secluded creatures get the only exercise vouchsafed them, since they are too exalted to go upon the streets even at night except in a closed chair.

A Gentleman's House.--Inside the host's quarters a set of two or four little eight-foot rooms are so arranged that the whole may be thrown into one large room by lifting up the doors if of one style, or sliding them back as is the common manner. The floor is covered with a rich oil paper that looks like brown marble, only it is nice and warm from the flues underneath so that if one has come in stiff from a chair ride in zero weather, his stockinged feet, from which a servant at the door has removed the shoes, begin to warm up most agreeably.

Great mirrors sometimes cover as much as one side of a room. Clocks and an ornamental cabinet or two, together with painted or embroidered screens make up the furniture, with mats on the warm floor on which to sit and smoke, and where the host lies down and sleeps when the time comes, for this is bedchamber and everything in the way of living-room. The walls are covered with white paper, as is the ceiling and the several sets of latticed windows.

These houses are all of one story and cover a great deal of ground. The compound of the American Legation which was our comfortable home for many years, covers three and a half acres of ground and was one of those purely Korean establishments, from the grounds of which numbers of buildings had to 


\section{A RAMBLE IN COUNTRY AND TOWN 67}

be removed or joined to others, in order to suit Western ideas and give space for lawns. The native architecture was preserved as far as was possible to the intense delight of visitors of an artistic temperament, who never fail to lavish praise over the effect of the beamed and raftered ceilings fully exposed, with neat white paper between the rafters.

However humble the hut of the peasant or coolie it always has its tight little sleeping room, the stone and cement floor of which with its rich brown oil paper covering, is kept nicely warmed by the little fire necessary for cooking the rice twice daily. In this respect these people fare better than do their neighbours, for the Japanese houses are notoriously cold, and a fire pot for warming the fingers is the only native system of heating, while the Chinese never are warm in the raw cold of winter. They have no means of heating their houses other than by a warmed stone bed which is used in the north, but in the raw cold of the central portion the houses are absolutely unheated and the people simply add more clothing in order to warm up.

The English traveller, Henry Norman, was strong in his praise of the beautiful country he passed through in making a journey across Korea, while as to the capital, Seoul, after he had visited Peking he wrote that, compared with Peking, Seoul is a paradise. 


\section{VII}

\section{A SEOUL NIGHT AND A REVOLUTION}

OuR first mail by the newly organized Korean post chanced to be Christmas mail and it was lost. The first post-office was destroyed by a mob which held the city in terror for some time after the outbreak of the bloody emeute of December 4, I884.

Conservative Koreans did not look with favour upon foreign innovations, one of the most marked of which was the establishment of the post-office.

We had only been in Korea a few months when this outbreak of conservatism took place. I had been dining out across the city that evening, at the quarters of two of my American friends who were stopping in Seoul. One was a business man who still makes Korea his profitable home, the other was a naval officer there on special duty.

A Peaceful Scene.-Returning through the quiet streets in the crisp cold moonlight, with the dry snow crunching under foot, the scene was so peaceful and homelike that I planned accompanying my wife out for a stroll. A residence in China had made us cautious about walking together through streets swarming with inquisitive and rude Asiatics. We did not then realize the different and more agreeable conditions that prevailed in our new home, where 


\section{A SEOUL NIGHT AND A REVOLUTION 69}

foreigners might wander at will with no fear of molestation. This quiet night seemed to be just suited for seeing the sights of the city to which we had come to make our home.

It was a silent night city. No whistles or passing cars disturbed the quiet. Not a single vehicle on wheels rolled by. The only equipage to be seen was the chair of an official swinging noiselessly past, while the hoof beats of the horse of a mounted official speeding to or from the palace, made no noise on the unpaved streets. One might hear the distant rattap-tap of the ironing stick wielded by some woman whose work was keeping her busy long into the hours devoted to feminine freedom: the cry of a restless infant, the barking of dogs, or the bray of a donkey, with the occasional uproar caused by the incantations of the native healers in some house of affliction, were the only other noises to be heard and even they were remote from the street.

No fixed lamps or lighted windows illuminated the almost deserted thoroughfares lined with blank walls of houses or enclosures. The only lights to be seen were those from the lanterns of the few pedestrians. Most of the people to be met were women, each one white clad and closely veiled, carrying a tiny paper lantern giving out a feeble glow from its beeswax taper. For from the tolling of the "curfew bell" for the closing of the city gates, until the opening of the same at dawn, all common men except the attendants of a person of rank, were excluded from the streets which were then given over to the women, who 
seemed to enjoy to the full this liberty of the city, and were taking this time to make their social calls and get some necessary out-of-door exercise. What better occasion could there be for the lone woman from a distant land to make her first progress on foot through the streets of this, to her, unexplored city.

Assassinations. - That was not to be, however, for underneath that calm an awful storm was brewing. Soon after my arrival home a messenger burst in upon us with a request from the American minister, that I come with all speed to the place where an official banquet was being given in honour of the opening of the post-office, and where murder had been committed.

After being rushed across the city under an escort of native troops, I found the foreign representatives and the high native dignitaries spattered with blood and terribly agitated, while the host of the evening, Prince Min, was lying at the point of death with arteries severed and seven sword cuts on his head and body. This man had just returned from America where he had gone to ratify our treaty with his country, and he was the greatest man in Korea next to his ruler.

It took three months of constant care, attended with much anxiety and peril, to bring the prince back to health and even then he was a badly scarred and worse scared Korean who, soon after his recovery, took up his permanent residence in China.

Japanese and Chinese Clash.-This emeute became a contest between the conservative party as- 
sisted by the Chinese, and the progressists aided by Japan. There were days of severe fighting and nights when the city was illuminated by the burning of the dwellings of prominent natives who had been assassinated.

The Japanese fought well but they had only one hundred and forty soldiers as against some thousands of Chinese troops. They were finally obliged to burn their handsome new legation buildings, abandon the palace, which they had seized and held, and fight their way across and out of the city and on to Chemulpo, leaving over forty dead lying in the streets where I saw the dogs devouring them during the next few weeks, while being escorted from place to place in making professional visits to the wounded Chinese and Koreans. There were no wounded Japanese, for all of that nationality who could not escape to some place of safety, were killed and thrown to the dogs.

The twelve Western foreigners, with a small band of Japanese refugees, were assembled at the American Legation, where regular guard duty was performed under the direction of the naval officer just mentioned, who later accompanied the Japanese refugees with a Chinese escort, to a ship at Chemulpo. For this he was afterwards honoured by the Japanese Government.

A Prince's Life Saved.-The prince at last recovered and his physician was honoured by being made medical officer to the court and maritime customs service, and was provided with a hospital in 
which to treat the thousands of natives who had conceived the most exaggerated ideas of the virtues of Western medical and surgical science, because of the fact that their prince had been saved thereby. Later on they actually brought me watches and clocks that had stopped or " died," insisting that I bring them to life.

A Useless Gun.-An amusing incident occurred during this trouble. I had left our only revolver with my wife, to use on herself and the baby if that became necessary, while I had borrowed a short, heavy carbine, which I carried with me constantly, to my great discomfort, and which reposed under our bed at night. When the trouble was over and all was again peaceful, I went out one day to try my marksmanship. The clumsy weapon could not be discharged, since the cartridges, of which the magazine was full, were too large for the calibre of the gun. It had served its purpose, however, in giving confidence and in warding off any attack that might have been contemplated but for its formidable presence.

The post-office was destroyed together with the little mail supposed to have been received, but the natives could not so easily thwart such a world-wide power as the postal service. Another and more successful attempt followed this one, thus providing several sets of stamps for collectors to gather and indicating the folly of trying to fight against modern progress. 


\section{VIII}

\section{KOREA AND THE KOREANS}

AccoRDING to the verdict of certain scientists our aborigines are supposed to have come from Korea. In the comparatively short time during which the Spanish kept records on our Pacific coast, over one hundred junks are said to have drifted across that ocean, along the Aleutian Islands and the Alaskan coast, in the track of the Japan current. This would indicate that considerable numbers of human beings may have so reached what are now our shores during the centuries that preceded the advent of the European.

When in Washington with the Korean Legation in I 888 , the then minister from Nicaragua expressed himself to me as much struck with the resemblance of the Koreans to the educated natives of his country. Certainly there is a strong resemblance between some of our native Indian tribes and the Koreans.

A White Man's Land.-Korea has been aptly termed " A white man's land." Although it is a continuation of Siberia, extending down between the Yellow and the Japan Seas, it has a climate much the same as that of our northern central states, with more equable winters, and a regular rainy season during two of the summer months.

The winters are one succession of bright sunny days with just enough gray days to relieve the mon- 
otony, and growing almost imperceptibly colder day by day until the great navigable river at the capital is frozen over so that the cart road is extended across the ice. The mornings are overcast until the sea breeze blows away the vapours towards noon. This gives to the country its name of the land of the morning calm.

Products.-The great product of Korea is rice, which is the staple of diet. Next come beans, which are largely used as a food for man and beast, being mixed with rice in the human dietary or used in the form of curd or cake, while they are indispensable for making the sauce so highly prized in Asia, and which is shipped abroad in vast quantities for the preparation of a celebrated English sauce as well as others, since it is the foundation for most of our sauces. Any one who patronizes a Chinese restaurant will be familiar with this bean sauce. Millet, rye, barley, oats, wheat and some poor corn, together with cotton and vegetables, form the chief farm crops raised in Korea after rice and beans.

Origin.-The Koreans are of Mongolian origin. They resemble the Chinese more than they do the Japanese, though if one of each of these nationalities is dressed in foreign clothes with no distinguishing mark, it is practically impossible to distinguish one from the other.

Language.-Koreans understand the common written characters of China, Japan and Korea, but they give these characters their own pronunciation, which has no resemblance to that of their neighbours. 
Mistakes. The Jetty.-We foreigners make some ludicrous mistakes in attempting to use the native language. When I went there there were no books that one might study, and I had recourse to books I had used in China. Soon after arriving I took up my Chinese dictionary and tried to use it in explaining to a man with a packhorse that he must go to the jetty on the river and bring me some freight. He promptly went to the horse's head and remained there. After considerable effort of a fruitless character, it dawned upon me that the Chinese characters used for jetty, meant literally horse's head, when taken by themselves.

A Nuisance.-At another time I tried to use my dictionary to tell a man that in my opinon he was a nuisance. He had been shot in the eye by the Japanese in 1884 , and I had removed the eye and the bullet, thus inspiring him with such gratitude that he persisted in spending his time in my office, to my great inconvenience. Now in China, be it said, if you save a man's life you are thereafter responsible for him as though you were his progenitor, and thinking that some such custom might prevail in my new home, I did not wish so soon to encumber myself with a family of that character. After hinting to him in various rather plain efforts that his presence was not desired, I finally took up my dictionary and finding the word for nuisance I pointed to it and told him as well as possible that he was it. The poor fellow seemed surprised and began sniffing about and examining his shoes, until it dawned upon me that I 
had gotten the wrong synonym, and called him a stench. He was allowed to remain after that.

Come On.-These two words sound just like the Korean expression for stop, and this similarity in sound of two such opposite meanings came near costing the life of an American. In I 886 this man was underneath a huge boiler that was being placed for an electric lighting plant. The load was supported by ropes manned by numbers of coolies. Desiring just a little more elevation in order to let the boiler down into its masonry bed, the American called out, "Now, come on," and every man let go of his rope as that was the order they were expecting. Fortunately the American escaped, but it was a very close call.

Perspire.-A young missionary was recently preaching to a mixed congregation, the men being seated on one side of the chapel with a curtain extending down the middle of the room, separating them from the women. He was very earnest in his rebuke of the Korean women, because they were so beset with the sin of covetousness, explaining that they could never hope to enter the kingdom of heaven unless they gave up that sin. Finally one old woman, unable to stand it longer, arose and announced that it was impossible to rid themselves of this failing. This only served to bring forth a stronger condemnation till the old woman interrupted the missionary to demand some medicine for the trouble, if it was so bad as all that, since any one might know that this was a thing which faith could not reach. The missionary's teacher thereupon arose and called his pu- 
pil's attention to the fact that while he was preaching upon the subject of covetousness he had been using the word for perspire.

First Convert.-The old man who cared for my office in the early days when my time was taken up with the wounded, was supposed to be my teacher had I had time for study of the language. He was a scholar and could read the Chinese text. I had on my desk, among other books, a copy of the New Testament in Chinese which this old man began to read as a means of passing the time that hung heavy on his hands. He became so interested in the book that on leaving my service he stole it. It was the means, however, of his conversion to Christianity and the strange thing about it was that though I was a Presbyterian and the book had been published on a Presbyterian press, it made a Methodist of this, the first Protestant convert in Korea.

It was like the case related by Dr. Grenfell, of Labrador, himself of the Church of England, who received through the kindness of a Congregational minister, the present of a pair of cork legs formerly worn by a Methodist clergyman, which legs Dr. Grenfell attached to a Catholic patient. There would seem to be more reason for straying in this case, however, than in the one that occurred to me.

\section{The Capital and the Official}

The City.-Seen from one of the sheltering mountains, Seoul presents a dull level of weathered houses, relieved here and there by trees, singly or in clumps, 
denoting the location of one of the residences of the better class.

The streets and alleys are usually well defined as white ribbons laid down in the mass of gray, for white being the national colour, as well as that of the mourners who form so large a portion of the Korean population, their garments lend their colour to the streets thronged with pedestrians.

White Costumes.-The use of white by a people whose surroundings are not immaculate may seem odd, but like other of their customs it had reason for its adoption. White being the mourning colour and three years the mourning period, it may easily be seen that with ordinary rates of mortality there must be many who are in mourning at any given time. Furthermore, when a royal personage dies the whole population must odopt mourning colours for a period of three years; it was quite natural therefore that the people should accept the inevitable and adopt the mourning colour permanently in order to be ready for what was pretty sure to happen.

The Wall.-A wall of heavy masonry about eight to ten feet thick and twenty feet high encircles the city, climbing the mountain peaks and capping the surrounding ridges, for a distance of ten to twelve miles. Great gates are placed at suitable intervals in the lower lying portions of the wall; some of them have bastions while all have great high pagoda roofs covering a sort of gallery, which forms a cool and comfortable place from which to watch the novel sights in the street below. 
The Curfew.-Formerly it was the custom to close these gates for the night, and in coming by chair or pony from Chemulpo our great anxiety was always to reach the city before the closing of the gates, otherwise we would be obliged to scale the wall by the aid of a rope let down for a consideration and in violation of law.

The closing of the gates followed the ringing of a great bell hung in a pagoda at the centre of the city, the tolling of the bell being accompanied by weird music similar to that of bagpipes, rendered by musicians placed in the pavilion over the gate at the governor's yamen.

After the closing of the gates the streets were reserved to the women, the men-except officials and their retinues-being excluded from the thoroughfares which were then made white with the processions of women with their little paper lanterns.

Signal-fires.-This gate-closing ceremony was preceded by the lighting of the signal-fires on a wooded, evergreen mountain which forms the southern side of the city and faces the palace. For in order to know the state of affairs in the country, men were placed on convenient peaks in a line extending in from the borders and these watchmen would build their fires on seeing the flash of those beyond. When these nearer ones were seen by the watcher on the South Mountain at Seoul he would build the requisite number of fires on his little altars in full view of the city and the palace, whereupon four old gray-bearded officials would go in and bow to the floor before their 
ruler and announce the message of the fires,-that all was peaceful on the borders, or otherwise. After this the business of the government would proceed throughout the night, in order that swift messengers might bear the mandates forth with the approach of dawn and thus the affairs of the people would be provided for.

The Official.-Every Korean of any ambition aspires to official rank, which after the satisfaction of the creature comforts, is the most delightful thing he may contemplate. Formerly any man might hope to obtain this end by successfully passing the competitive examination open to all. This quaga was one of our great sights in the early days, when hundreds of scholars from all over the country would be seen seated on the ground in an enclosure at the back of the palace, industriously writing essays on some subject taken from the Chinese classics, and thus striving on year after year, as in China, to lift themselves up from the lot of the commoner to that of the desirable official class. And what a luxurious picture the official presented to his less-favoured brother in that secluded land, where outside impressions were restricted to those obtained secondhand from the great neighbouring Middle Kingdom, which to them embodied all that was worthy of imitation.

When the yangban, or man of rank, moved out from the home where he held a petty court, even if his subjects were perforce but women and children and a few half starved servants, he went in state. If 
too poor to ride he would stride along with such an overpowering air of condescension that the very street seemed honoured by having its dust so trampled. He would in turn be most subservient when a fellow yangban of higher rank appeared, mounted on a donkey-that beast so delightful to a native of sufficiently high standing to be allowed to keep and ride one. But even the proud rider of the donkey would hie himself up a side street or hastily dismount and stand to one side, as far down the street was heard the familiar call of the outrunners of some great noble, snugly ensconced in a comfortable closed chair borne on the shoulders of four men, with numerous attendants. These outrunners moreover were, until recent years, equipped with long paddles with which they would soundly whack any of the common herd who should neglect to dismount, to remove the ever-present pipe from the mouth or fail to rise if sitting down.

How fierce these fellows seemed, armed with authority and sure of the protection of their powerful master. My own chairman, even after I became the representative of the United States, could with difficulty overcome their fear of them and the effect of old custom, and would regularly step aside, even into the ditch, and hold me there for the procession to pass. One day, however, my insistence upon a contrary course brought on a collision from which the foreigner emerged with such glory that thereafter it became difficult for me to restrain my haughty bearers from going to the opposite extreme;-so 
easy is it for a downtrodden race to assert themselves once the pressure is removed.

In the train of this noble, riding along in his cozy chair, there would be in addition to the outrunners and personal guard, a custodian of the seals of his master which would be borne along in a brass-bound box. Another man would bear in a case strapped to his back, the uniform to be donned at court before going into the presence. There would be the pipe bearer whose duty it is to light his master's pipewiping off the mouthpiece on the inside front breadth of his skirt thereafter. Then there must always be the man bearing the vessel of convenience without which no gentleman would go abroad.

Should a man of this class go out on horse or donkey back, he would be supported on the ridiculously elevated saddle, by a man on either side, while another would lead the animal, the rider holding meantime to an iron ring projecting up from the saddle.

After having dismounted, or on emerging from the closed chair, with much assistance and smoothing of gowns by the attendants, two servants take their master under the arms and practically support his weight as he mounts the steps of a building, as though one so exalted had little use for feet when so occupied with mental labours and matters of state.

It is no wonder that every Korean dreamed by day and night of this delectable state for which he could not but long with all the depth of his nature, and that all the stories of their interesting folk-lore 
should have as their climax the acquisition of rank rather than success in love as with us. They were enough unto themselves. They wanted nothing not within their own reach. Nothing that the outside world might offer could compare, in their estimation, with this, their own most desirable state of blissful superiority and command. As for the common man, he got some compensation in robbing the official on every possible occasion, which was by no means seldom; his creature comforts were supplied and his children might aspire to the class just described.

Press of Modern Life.-But these halcyon days have passed never to return, for the hermitage has been invaded by the press of modern life, and a reversion to the happy days of comfortable aristocracy and abject poverty is impossible, however much the poverty may persist or be increased. The telegraph has relegated the signal-fires to a mere memory. The electric light is taking the place of the paper lantern. The trolley has compelled the opening of the city gates at night and made the streets free to all, while the great bell now tolls for noon and midnight as though loath to abandon its time old office. The palace is but an appanage of the Japanese residency and there is precious little respect shown by the haughty little representatives of Korea's present overlords, who would make short work of an official retinue that should try to brush them off the street on the approach of a lord of the olden time.

Off in some distant valley where gold or rich crops 
may not have tempted the overbearing foreigner, some yangban of ancient lineage and inborne aristocratic tendencies, may still live the life of his ancestors in the seclusion of his deep recess, shut in by pine clad mountains, where his uncontaminated and unsophisticated neighbours may pay to him the ancient homage due to rank and scholarship. But in the capital the men of the old régime must content themselves as they may with dreams of a vanished glory, while seeing the sons of their late retainers rise above the scions of the ancient house, as they develop a greater adaptability to the new conditions prevailing in that once quiet land of the morning calm and peaceful eventide.

\section{The People}

Naturally where politeness was so long compulsory, the people have been so bred to it that this trait is quite noticeable. Further, in ancient times Korea ranked high in matters of etiquette. When I first reached the country one of the cabinet officers held the portfolio of etiquette and ceremony.

Bicycle Politeness. - I have seen a Korean, accidentally thrown down on being run into by a bicycle, gather himself up from the ground and even before brushing off his soiled garments, apologize for being in the way and thus causing the rider inconvenience.

A Fall Down a Shaft.-At one of the foreign gold mines, a notice was conspicuously posted at the mouth of the shaft, forbidding all people from entering the mine without permission. A native, seeing 
the announcement and having the usual curiosity to ascertain what the proclamation might mean, approached so close to the opening that he fell down the shaft. The foreigners hastened to the bottom expecting to find the man but a mass of mangled remains, when to their surprise they found he was not much hurt, and as they approached he became profuse in apologizing for having inadvertently entered the mine without permission. He seems to have had just time to make out the sense of the proclamation when he lost his balance and violated it.

Curiosity.-Having so few amusements and being inclined to idleness, in a land where life has long been compatible with a modicum of labour and much consequent leisure, the people are naturally inspired with a consuming desire to see or hear some new or interesting thing. Anything out of the ordinary will therefore serve to attract an interested company.

Cyclometer.-I often had such a crowd about my bicycle, especially if I stopped by the roadside to " feed it wind," or to make some slight repairs. On one such occasion a spokesman, as usual, appointed himself, and, after explaining to the others how the thing ate wind and went itself-with the speed of a bird, he was called upon to explain about the cyclometer. This he promptly announced to be a clock so placed that the rider could tell the hour without stopping. Not wishing to tempt the people by letting them suppose this to be a clock, I joined in the conversation and told them of the workings of the cyclometer. Mr. Spokesman then asked how many miles 
it registered. I replied that it showed I had gone six thousand of their miles, or two thousand of ours, whereupon he asked in all good faith if I had done that distance since breakfast. It was not yet noon.

Such strange things were done by the foreigners with their queer contrivances, that if I had told them we could communicate with the moon, I think they would not have been greatly astonished.

Bicycle Railway.-Once a venerable old man came up to me in his gentle, kindly manner, as I was carrying my wheel over the stepping-stones across a brook, and showed much curiosity regarding the machine. I let him examine it and pleased him greatly by showing him how to ring the bell, which never failed to gratify them. Having satisfied himself, he stepped to one side and regarded the machine for a while when he remarked, "Well, well, I suppose this is the new thing called a railway, of which I have heard so much."

Rapid Railway Building.-One old man who at first was rather skeptical about these foreign undertakings, became convinced of foreign ability to an extent that was hardly to have been expected, and that was most amusing.

He was about to make his first trip from Fusan to Seoul by means of the foreign fire-eating ships and engines. Often had he toiled from thirteen to twenty days on that journey overland, but now he had come into the settlement intending to do it in two sleeps as had his neighbours, thus saving much money-not to mention less valuable time. 
At Fusan he saw men building the grade of the Seoul-Fusan railway and being told what it was he laughed knowingly and remarked that their hair would be whiter than his before ever they reached Seoul with that dyke, for he had built dykes around rice-fields all his life and he knew what the work meant.

His comfortable trip up the coast was a revelation. Plenty to eat, much to see, and just enough gentle motion to induce a continual sleep.

From Chemulpo, on the railway train, he was almost too astonished to smoke as he saw the people in the fields rush past him. Finally, taking courage from his fellow passengers, he sedately lit his pipe and had only "spit out of the window twice," when they arrived at the then terminus, where other workmen were constructing the Seoul end of the SeoulFusan railway. On being told what this was, the old man supposed these were the same men he had seen at work three hundred miles away and that they had completed their task.

All he could do was to squat weakly on his haunches and exclaim " aigoo," as he called upon the spirit of his maternal ancestor, as though demanding of her if she had ever heard of any such dyke building in her experience.

\section{TRANSPORTATION}

The native means of transportation is by heavy bull cart or junk, or by pack borne on the backs of bulls or ponies, men or women. People walk, ride 
ponies, or are borne in chairs. I have been carried twenty-five miles in a comfortable chair repeatedly, doing the distance in as few as five hours, with four men in the poles and four others to run alongside and "spell" the bearers. In such cases it is very desirable to have a good story-teller among the men, one of good wind who can keep at his tale while bearing the load along at a dog trot. He will rattle off his yarn in fine shape while the others trudge on with eyes on the ground, drinking in greedily the interesting story and thus forgetting how long it takes to cross a valley or climb a mountain pass. At every climax of humour there will be one unanimous burst of appreciative laughter, and the crew fetch up at their destination comparatively fresh and in good time. Without this means of beguiling the tedium, every wine shop will be eagerly sighted in advance, and by the time the journey is well under way the heavy feet of the bearers will require frequent stops on any and all pretexts.

Even for the pedestrian travelling is expensive, for shoes must be bought even if they are but straw sandals, while food by the way must be paid for before being eaten. All this makes the railway very popular. A man would walk the twenty-five miles from Seoul to Chemulpo, do his errand, and return the next day. He would require at least four meals while away, which would cost forty cents. He could go down and back in one day by the cars at little more cost and carry with him a considerable load, the third class having been made very reasonable. 
The Pony.-The Korean horses are wiry little ponies with plenty of fight in their make up. Those met on the roads are usually stallions, the mares being used elsewhere, as is the case with the bulls and cows. The bulls which make up numerous packtrains, however, are more docile than are the ponies.

I well remember my first experience with one of these ponies. It occurred on the morning after my arrival at Chemulpo, in 1884, when I started with my Chinese teacher to ride to Seoul. As I approached the horse he attacked me viciously, first with his heels and then with his forefeet. The grooms tried to restrain him, and frantically motioned to me to keep away. They then covered his head with one of their long robes, and I took a running jump and landed in the saddle. I had brought with me a foreign saddle, otherwise I might have been compelled to ride on a pack frame and would probably have been thrown, for the beast plunged and tried to buck, but his education had fortunately been neglected, and the nearest he could approach to this accomplishment was to run hard for a while and then come to a sudden stop with his forefeet planted rigidly. Once he jumped upon another horse and knocked off the rider, but I could not stop to apologize, and except for dismounting for my lunch and to feed the animal, which necessitated another running mount with the horse blindfolded, I remained on his back, even while being ferried in a small boat over the river. Had he capsized the boat or jumped overboard, as I half expected him to do, I think I should have clung to him, 
for his back was a vantage post not to be lightly relinquished.

A friend of mine rode this beast up country on one occasion, where he met the pompous procession of a proud magistrate riding into the district to which he had been newly appointed. The people were lined up here and there to witness the procession and to greet their new governor, while the overbearing yamen runners were ahead on the road demonstrating their zeal to their new head official and clearing the road of all common people. These were followed by men with long trombone-like horns, upon which they blew lustily in announcement of the great man's approach and to warn the people off the path. The unheard-of sight of some one riding, therefore, in the face of all this dignity and warning, so incensed the runners and horn-blowers, that they redoubled their efforts and dashed down as though they would annihilate both horse and rider. My friend felt a little as though he deserved it, but the horse felt otherwise and seemed to breathe a freer air of liberty than that of those adjoining rice-fields. At any rate he took things into his own hands, or rather into his mouth, for he made a dash at the first horn, seized it in his mouth and flung the owner into the soft mud of the paddy-field, where even the great official himself was hastily carried, while the steed had the road all to himself and my friend, whose sense of humour is highly developed, called out the Korean salutation of adieu, or "peace be with you," as he galloped by. It was related that that magistrate was so humiliated 




PONIES WITH PACK FRAMES

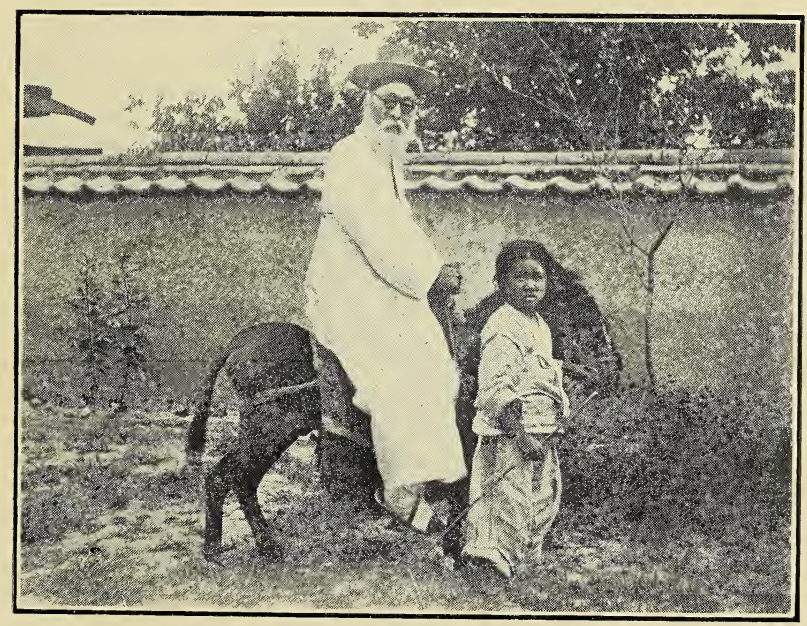

THE DONKEY - THE PRIDE OF THE LESSER OFFICIAL 

by this his undignified entrance into the domains of his new post, that he soon secured an exchange to one far enough away to be removed from the disagreeable repetition of this story.

The Donkey.-Formerly, when a man had attained a certain rank he might ride a donkey. This gentle animal therefore became the pride of the hearts of the lesser officials. A donkey with a good loud bray and a tendency to exercise his vocal organs was most highly prized, since every one near would, on hearing the noise, realize at once that that was the house of an official, while the less favoured neighbours would take pride to themselves from the thus loudly proclaimed fact that theirs was a donkey neighbourhood.

Squeaking Gates.-Another noise, distressing to the foreigner but delightful to the native, was the awful rasping of a great gate being moved on its unoiled hinges. These gates, leading into walled compounds, are massive affairs of heavy plank about eight by ten feet in size, iron bound and studded with nails. The noise of one in operation may be imagined, but nerve-racking as this noise may be to us, it was as delectable to the Koreans as was the bray of the donkey, for it indicated the location of the residence of one of the gentry, and the whole neighbourhood rejoiced in the sound; while those too far removed to be able to run out and see who was entering or leaving, would still have a subject for conjecture as to the identity of the one for whom the gate was opened. Of course any little folk would go through the com- 
mon side door similar to the one opening into their own small houses.

Chinese Wheelbarrows.-An Asiatic noise even more harrowing than that made by the gates, is that produced by the unoiled wheelbarrows on which poor Chinamen push great loads of brick and other merchandise in Korea, or people and merchandise in China. These toilers will not, moreover, use grease to stop this noise even when it is given them; they seem to enjoy the screaming and groaning of the hot hard wood.

A Donkey Incident.-Speaking of donkeys reminds me of a most amusing incident I witnessed in Nanking. A rather peculiar missionary there was one of our neighbours. He was tall and slender and kept a very diminutive donkey which he persisted in riding though his feet would touch the ground when let down. One day I met this man returning from market with a large assortment of tinware tied together and suspended around his neck. He wore a very long ulster which hung down over the hind quarters of the donkey so that simply the little hoofs of the animal and the tip of its tail were to be seen from the rear, while the head of the rider, protruding from the top of the ulster, seemed to be the other end of the body to which the hoofs were attached.

I realized then how full of humour the Chinese are, for they simply roared with laughter at the strange sight, which amused me as much as it did them. This laughter annoyed my acquaintance and his 
movements disturbed the tinware, the rattling of which so displeased the donkey that he threw his rider and his rattling load right over his head into a mud puddle. Unfortunately the American lost his temper and said and did things which are no part of this story but which simply added to the merriment of the good-natured crowd, who certainly enjoyed to the full this discomfiture of the foreign devil.

Kerosene Tins.-This man's load of tinware was manufactured from discarded kerosene tins. It amuses travellers to see the uses to which the Asiatics put these five-gallon tins in which our kerosene reaches them,-packed two each in neat wooden cases, which cases also find innumerable uses. Water-carriers use the tins slung on a pole strapped to a frame on their backs. Houses are roofed with them, the tin of course being flattened out. With the ends removed and a number soldered together chimneys are formed. A Chinese cook, with his wonderful native ingenuity, will plaster the inside of one such tin with mud, leaving a vent connecting with a fire hole below, and on this improvised range he will prepare a creditable course dinner off in the country wilds. All manner of cooking and household utensils are constructed from these tins, as well as lamps, candlesticks, toys and ornaments. In fact it would be a serious matter for the natives if they did not have the convenient kerosene tins, which consequently have, together with empty bottles, a regular price and usually form one of the perquisites of the servants in a foreign establishment. 


\section{OCcupations}

Rice Culture.-The Koreans are an agricultural people and farming is the chief occupation, rice being the principal crop. Rice culture by the old methods practised in the Far East, involves much hard labour. The fields must be made level, involving the construction of terraces, tier above tier, with little dykes separating one level or field from the others, which dykes must hold water. Sometimes the water must be raised from a lower to a higher level instead of being simply run off from the upper to the lower fields. For this purpose a crude sort of water-wheel is often arranged, sometimes being operated by animal power. The common method, however, is by the use of a kind of scoop shaped something like a shovel and hung on a tripod; the farmer works the handle of this appliance and with every thrust scoops a lot of water from the lower to the higher field.

Seed rice is first sown in a small, carefully prepared patches, from which the plants are taken in bunches for transplanting. When the wet fields have been well manured, plowed, and harrowed, with the clumsy tools drawn by great bulls wading up to their bellies in the mire, the bunches of young rice, each tied with a strand of straw, are thrown about in spots convenient to a row of men and women who wade out and jab a few stalks of the rice taken from a bundle, into the soft mud in fairly regular rows. These soon take root and thrive, after which weeds must be kept down, water must be let on in proper amount, 
and birds must be kept off when the grain is ripening. The cutting is done with the ground comparatively dry. The sheaves are then laid on the dykes or on a hillside to dry out for threshing. The threshing is done on a prepared clay floor by means of a flail. The rice is then husked in hand mills made of serrated sections of a tree trunk fitted together for grinding. After this is done the close envelope is removed by pounding in a stone mortar with a wooden or iron pestle. This results in many a broken tooth from biting upon a piece of stone that has been chipped off in this process and become mixed with the now white rice.

Three-man Shovel.-The Koreans are very ingenious in their use of the shovel. Its use for raising water has just been noted. For turning over soil, ditching or any work requiring the raising of earth, they use a broad shovel with a long handle, having a rope attached to either ear of the blade. One man will guide the handle while one or two men will pull on each rope, thus employing from three to five men for each shovel. When working this instrument for themselves they certainly do great execution with it, but when working for wages they are apt to make of it a very labour-saving contrivance.

Plows.-The native plow is a very crude affair, heavy to handle and with a flat blade or shovel which makes hard dragging for the plow animal and is very inefficient in sod or hard ground, while at best it only tickles the surface. Our plows were introduced by our missionaries and greatly appreciated by the na- 
tives, but they seem to have gone back to old custom, preferring to do as did their fathers and forefathers rather than suffer the odium of introducing some foreign innovation.

A Test of Strength.-The natives are well built and strong. Some coolies engaged in carrying goods from the jetty at Chemulpo to the warehouse of an American-a distance of about one mile-bantered one of their number to carry a bale of sheeting of five hundred pounds weight that distance. The others placed the bale on his frame and he actually carried that weight a mile without further assistance. Thereupon the guild of pack coolies set upon him and gave him a severe beating because they claimed he had spoiled the market for their labour, since thereafter every man would be expected to do the same.

Labourers.-They are good labourers on the railways and other large construction work, in which they soon fell into the contract method which seemed to appeal to them. They are good miners in the foreign mines at twenty-five cents per day of our money. They are the farmers in the region of Vladivostock who supply the city and garrison, and in Hawaii they are prized above the Japanese labourers because of their docile, industrious and frugal habits.

The Laundry.-The women labour in the fields, sometimes knee-keep in the mud and water of the rice plantations. They also engage as porters and peddlers along the roads, such, of course, being poor creatures reduced to this work and unable to pre- 
serve the seclusion so dear to their more favoured sisters.

In cities the chief occupation of the similar class of women is that of the laundress. The washing is done wherever there is a brook and even at the sides of wells, the water sometimes finding its way directly back into the well from which it was dipped. All about the cities wherever there is a little brook or spring, there may be found a company of women with their paddles, pounding clothes on smooth stones in the water. In winter the ice is broken to allow of this cold and disagreeable work, for with white clothes worn by all, washing becomes a most necessary occupation.

The Mangle.--Instead of ironing the clothes they are mangled or pounded, so that they take on a silky lustre-this is especially the case with garments made of grass cloth. The cloth to be mangled is wrapped around a large wooden roller or folded and laid on a block of stone. Usually two women will seat themselves on the floor opposite each other with this roll between them, and armed with what looks like miniature ball bats, they will rapidly pound the cloth, the four blows producing a rhythmical sound so peculiar as not likely to be forgotten when once it is heard.

Woman's Weapon.--This mangling seems to be done, to a considerable extent, at night, and the musical rat-tat-tap of the Korean laundry was one of our most common nocturnal sounds when living near the natives.

Occasionally the noise would cease for a time, indi- 
cating that some neighbour woman, more fortunate in completing her work, had come in for a bit of the gossip to which these women of narrow lives are so given. The common subject of such gossip was likely to be a domestic quarrel among their acquaintances.

One of the curses of the country is the plural marriage, or more properly speaking, concubinage, since the introduction of another woman into the family, even if she were given a separate establishment, was sure to give rise to bitter envy and animosity.

Possibly the newcomer, in honour of whose advent the ironing had ceased, would tell of how "Kim's wife" on learning that he had taken a concubine, had become so enraged that while scolding him in tones audible to the whole neighbourhood she had worked herself into such a frenzy that she had pulled out handfuls of her own hair, and when $\mathrm{Kim}$, annoyed at the publicity given to his shortcomings, had called her a name that bore a reflection on her ancestry, she had seized her ironing-stick and beaten him over the head until he fell dead (unconscious).

The secluded women of China and Korea are certainly long-suffering, but when pressed too far they will turn and the fury into which they then work themselves is something awful to contemplate. The ironing-stick then becomes a reliance not to be despised and one of which the stronger sex may well stand in awe.

A Fight.-One requisite for a fight between two men is the presence of peacemakers, but when it is a 
fight between man and wife the former, if decidedly in the wrong, will usually take what he deserves in the way of tongue lashings in dogged silence, but sometimes it will be different and he may resort to extremes.

Two men may begin a wordy battle, separated it may be by the width of the road, across which space they proceed to describe their grievances. They are polite and the man who has the floor keeps it until either his arguments or his breath fail. They are splendid talkers and this discussion is maintained in loud tones so that all the neighbours and the wayfarers may hear.

Soon an interested crowd assembles and their presence naturally lends inspiration to the performers who redouble their efforts, until one of them may finally wind up a severe tirade with a question addressed to the crowd regarding the quality of the ancestors of a person who could conduct himself as his opponent has done. This will cause the other man to start across the road for the maligner of his progenitors and then the self-appointed peacemaker will step out from the crowd and attempt to restrain the valiant one, who, finding himself in firm hands, will struggle with well-feigned eagerness to get at his antagonist, who by this time is himself struggling in the hands of his own peacemaker. Should one of these men actually wish to get at his enemy he can simply jump out of his loose garments, which will be left in the peacemaker's hands; sometimes this happens accidentally and an unintentioned en- 
counter is precipitated. Ordinarily, however, the personal violence done on these occasions is restricted to pulling hair or possibly drawing blood from an accidental bump on the nose. Blood never fails to calm both parties and cast a spell over the crowd, probably because of its marked effect upon the white garments thus ruined.

Real fights are sometimes seen, however, as was one I witnessed soon after reaching the country.

A Fatal Encounter.-Riding along one day I saw two men quarrelling in front of a house on an elevation ahead, and as they punctured the air with gesture and epithet I smiled to myself at this puerile method of fighting and really longed to see them go at it properly. I had my wish granted rather unexpectedly, for just as I got opposite them each man threw off his sole remaining upper garment and, bare to the waist, they ran at each other. One of them ducked and caught the other by the thighs, using the momentum to throw him over his head,-a wonderfully neat trick. A woman had rushed out of the house as the two ran at each other and her screams and wailing now took the place of the previous war of words. Suspecting from the woman's lamentations and the fact that the man lay where he had fallen, that something serious had happened, I went up to see if I might be of any assistance, and found the man was dead, his neck having been broken by the fall. I never again allowed myself to wish to see any more severe fighting than the ordinary wordy warfare. 


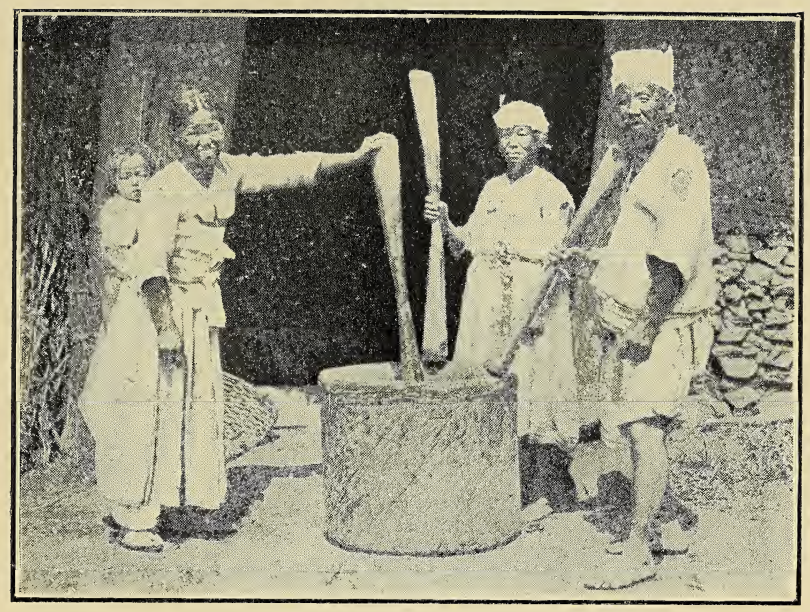

PEASANTS HULLING RICE

See page 94

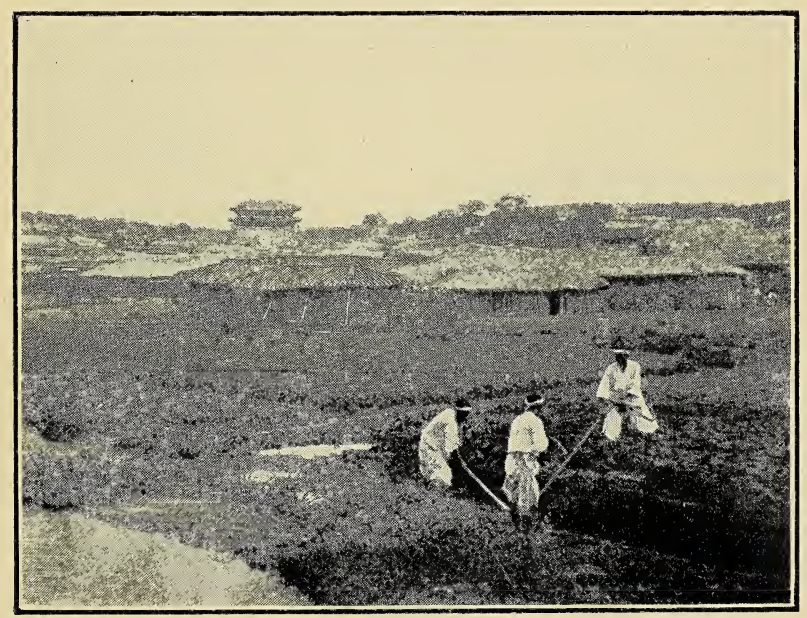

THE THREE-MAN SHOVEL

See page 95

City Wall in Distance, Showing One of the Smaller Gates 



\section{Manufactures}

While purely an agricultural race the Koreans have from olden times manufactured what they needed for their own use. They raised their own cotton and wove it into cloth. They do not use wool, as sheep do not thrive in the country, owing to the presence of a wiry grass that seems to be fatal to them. For winter use the cotton garments are simply padded with cotton wool.

Fat in Winter, Lean in Summer.-I became acquainted with one of my early native friends in the winter season when he seemed to me to be a large, portly man. He went off to his official post and I did not see him again until along in the dog days, when he came dressed in garments so transparent that when his flowing outer garment was removed and he stood between me and the light, his whole lower anatomy was plainly visible. I could hardly believe that this lean individual was my portly friend of the wintry days, until I had considered the layers of cotton wool he had shed with the advent of hot weather.

The native cloth, woven by the women on little hand looms, is still much used for undergarments because it stands washing well, but the smoother imported sheeting is taking the place of the former for use in making the outer garments.

Brass Work.-Excellent work is done in brass by these people, the pieces being turned on little lathes in the houses, after having been first cast in as near the desired shape as possible. The dinner service of 
all who can afford it is made of these fine heavy brass articles. Numbers of sets of bowls have been taken from the country for use among foreigners as finger-bowls, for which use they are admirably adapted, being unbreakable and taking on such a lustre as to resemble gold. Girls save up their money and invest in pieces of this brass against the time of their future marriage. The poor are obliged to use the very heavy pottery made in the country since the time when the makers of fine pottery were carried off to Japan.

Inlaid Work.-Besides inlaying on wood with mother-of-pearl in a neat and most attractive pattern, they do some very nice inlaying of silver on iron, the pattern being first cut out in the iron, after which silver is beaten in, making a very attractive work.

They are good carpenters, cabinet-makers and joiners, though not nearly so deft as are the Japanese. Some of their old chests are works of art and are very highly prized by foreigners. Bamboo and woven work, such as transparent window shades, are common, and some very fine matting is produced in lengths suitable for a bed.

No Incentive to Produce.-In a land where the collection of taxes was farmed out and every office had its recognized price, as in China, the rapacious official became a curse, and there was no incentive to manufacture, or raise more than was necessary to meet immediate needs. The accumulation of visible property was therefore found to be a mistake, since it but served to excite the cupidity of the lynx-eyed 
yamen runners, who seemed never to be at a loss for some pretext upon which to hale a man of thrift before the magistrate, from whose clutches escape was impossible without a payment assessed to the supposed limits of the poor fellow's ability to pay.

The "Squeeze."-An official friend of mine, himself a very successful hand at "squeeze," was in turn haled before the supreme court and squeezed by a higher power. In commenting on this he said to me that it seemed as though the possession of property by a Korean was regarded as a crime. He certainly was in position to speak authoritatively on the subject, though I could excuse him for much of the complaint made against him by the people who had suffered at his hands, since he was obliged to follow the customs of the land and get back what he had paid for his office, together with the necessary profit.

The uninfluential peasant or labouring man had ample reason therefore for not attempting to accumulate visible property. He simply wanted enough to keep him warm and to satisfy his hunger, tobacco for an almost continual smoke, and a little wine now and then to make him forget his lot. These with sons to honour him while living, and to sacrifice before his tomb when gone, made up the list of his desires. About the only thing he could be sure of keeping to himself was what he had eaten. Any surplus was therefore usually spent upon something in the nature of food or that could be secreted as securely as though it had been devoured. 
Eating a House.-It was not uncommon to hear it said of a man who had disposed of his dwelling, that he had " eaten his house," meaning that he had converted the proceeds into a feast or put them where they were as safe as though eaten.

In a fertile country, the supplying of the few wants above enumerated, does not require undue exertion, and ample time is left for sitting on heels under a hillside tree and gazing over the surpassingly beautiful valleys, or watching the travellers pass on the winding road below, while continually puffing out clouds of smoke from the rather rank garden tobacco.

Amusing Attitudes.-Seen from the car windows these figures have a somewhat ludicrous appearance even to the initiated. The queer, stiff gauze hat, with its wide rim and tall truncated cone, is carefully held level on the head of a gentleman, but the common man may not wear all the apparatus underneath to hold the hat in position, consequently his hat is usually tilted back till it catches on the top knot to which it is held by the chin band, thus giving him a childish appearance of curiosity, such as is seen in our youngsters with their hats on the back of the heads and mouths agape while looking at some curious object. Thus, with his white garments bunched up about him, he squats on his heels and gazes down on the train in a condescending manner as though himself quite superior to any necessity for such an absurd and bustling method of locomotion. With the long bill-like pipe protruding downward 
from the mouth, this sedate figure seems not unlike some great bird such as one sees perched on rocky headlands off the Hawaiian Islands, and as the pipe is removed and the black hat is seen slowly to turn at the shrill blast of the locomotive whistle, one almost expects to see the white figure spread its wings and sail majestically away as does the ocean bird when disturbed by the noise of a passing ship.

Merchants.-There are guilds of merchants who occupy quarters at the centre of Seoul, where in addition to regulating the trade of the country in their specialty, they conduct a sort of banking business. A note, draft, or order for the future or distant payment of money, is written in a column on a piece of the parchment-like paper; this is sealed with red ink and then the paper is cut lengthwise through the seal and the column of characters. These two halves when brought together must match, so that counterfeiting is made rather difficult.

The headquarters of these guilds are quite extensive, occupying, prior to the advent of foreigners, the only two-storied buildings outside the palaces. A small bazaar is maintained near these buildings, where customers may sit on the porches and have goods brought out and displayed to them. As a rule, however, goods are taken to the house of an intending purchaser for inspection, as there is practically no shop display, all articles of value being kept inside under lock and key, while the merchant sits crosslegged at the door of his little booth and seems not particularly anxious to show his wares. There are 
little shops for metals, pottery ware and eatables, along the streets with the wares laid out for display where the sidewalk should be if there were one.

A purchase requires much bargaining, as fixed prices are not maintained and a customer is sized up to see how much he will be likely to stand. Also the native servants usually receive a commission for all purchases even if they have had nothing to do with the transaction. I once stopped my horse in front of a shop and had my native attendant ask the price of an article. The dealer told him it was fifty cash and he turned at once to me and said it was one hundred and fifty cash. This was rather on the getrich-quick order of doing things and resulted unfavourably to the servant, as I had heard the price first named.

Wholesale and Retail. - Apparently it would seem that Korean merchants reverse our accepted relation between wholesale and retail transactions. A business friend of mine once desired some article of export that he might assist the people in paying for the imported goods for which their purchasing ability was not equal to their inclination to buy. $\mathrm{He}$ decided that some small round mats, such as are now on sale in our home stores, would serve the purpose well; he therefore called in a native merchant of standing with whom he discussed the matter. The merchant declared he could get any quantity of these mats at twenty-five cash each (about five cents), and my friend accordingly ordered five thousand of them. The poor native gasped in astonishment as he faintly 
repeated the order, and on collecting his senses he said he thought he might possibly get that number in time, but if so many were wanted they would cost fifty cash apiece. He had probably never before thought of so many mats at one time.

\section{Houses}

Korean houses are all of one story. The better ones have roofs of tile which have a concave slope, causing the projecting corners to curve upward in a very picturesque manner.

In building a house the roof is constructed first, that is the great timbers are erected on large stones set in prepared beds; heavy beams are then mortised to these uprights. Usually the whole log, neatly dressed, is used for the cross-beams above which comes the support for the stringers which hold the heavy round rafters. The rafters are covered with a close layer of split wood, and upon this layer is placed a thick coating of earth in which the tile are imbedded.

The floor is next prepared. For the rooms to be heated a system of flues is built leading from a fireplace (which fireplace also forms the kitchen in a small house) under the floor to a chimney which may be some feet from the building. Over these flues is laid a floor of flat limestone which is neatly cemented and finally covered with the thick rich oil paper of the country, thus making a tight floor through which the smoke is prevented from escaping into the white papered room. 
The walls of the house are filled in after the roof and floor have been prepared. First a wattle arrangement, corresponding to our lathing, is put in around the windows and doors and between the uprights; upon this neat coats of plaster are laid and the whole is covered with white paper on the inside when dry. These walls, on their outer aspect, are given a rather imposing and substantial appearance by being faced with stones to the height of a man, thus protecting the plastered walls from the weather; the unfaced portion above being protected by the wide overhanging eaves. These stones, about the size of cobblestones, are laid with their smoothest face out; they are simply stuck in a bed of mud and tied to the framework of the house by straw rope, but when neatly plastered between each stone they present a fine appearance so long as kept in order.

Sanitation.-This is largely characterized by its absence. A British consul-general in Seoul, who was Irish by birth, once assured me that the Korean peasant houses were more comfortable than and quite as clean and sanitary as are those of the Irish peasants. While pigs and fowls are not allowed in the Korean houses as in the Irish ones, unfortunately the chief adornment of the front gate or door is apt to be a slimy pit into which the filth and rubbish are dumped to ferment against the next plowing time.

Smells.-During the slack farming season the roads are made malodorous by a continuous procession of bulls and ponies laden with great panniers of this fer- 


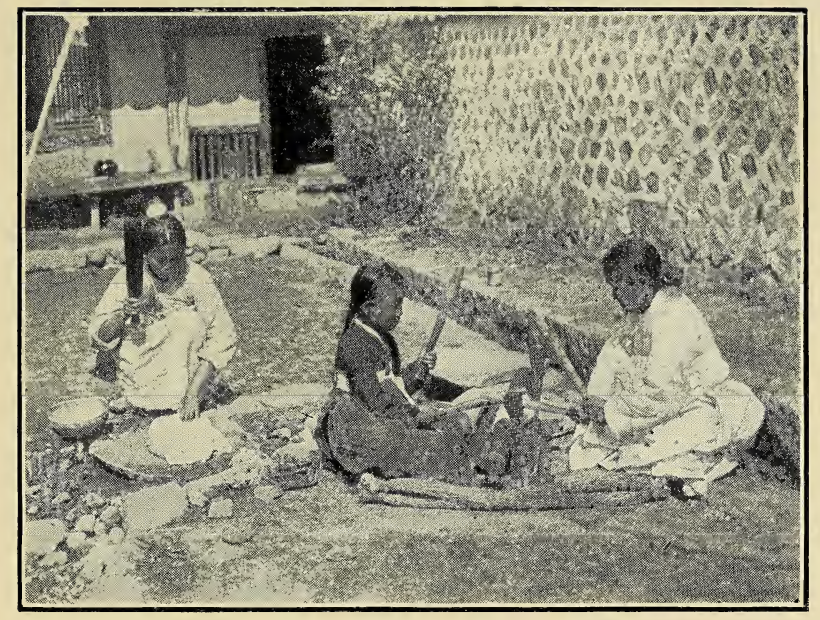

THE LAUNDRY AND MANGLE

See page 97

"Woman's Weapon"

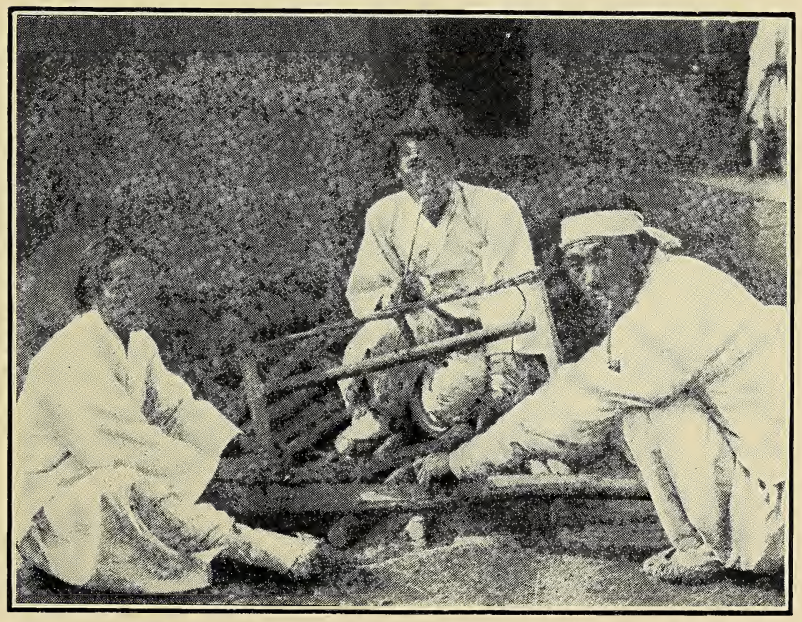

THREE MEN SAWING ONE STICK

Two to Saw and One to Hold 

tilizer which is being packed off to the farms. It is the long-to-be-remembered meeting with one of these noisome caravans that gives visitors the ineradicable impression that Korea is a land of filth and smells. The smells are certainly rather rank at times but they are nothing like so poisonous as were those from the old Chicago River when a tug plowed through the stagnant mush and allowed the escaping gas to rise and stifle pedestrians on the bridge.

In China the handling of this fertilizer is rendered even more objectionable, for there men are to be met in the crowded streets at any time of day, bearing dripping buckets of this fresh material swung on shoulder poles and causing the air of the whole street to fairly reek.

The natives have become inured to these odours from long experience, but it is really astonishing how they can thrive and still breathe the poisonous air of their little eight feet square sleeping rooms, into which six or eight persons may crowd and sleep on the heated floor. The odour encountered on opening the door to enter one of these rooms is beyond description and would drive a white man out into the worst of weather choking for breath. It must be that only the fittest have survived. I have seen Chinese and Koreans asleep on the edge of a cesspool or drain, on a hot afternoon with the sun beating down on their unprotected heads and the flies walking all over them and into their gaping mouths, leaving tracks of the slime from the near-by pit, and yet they seem to thrive. 
It is said that when $\mathrm{Li}$ Hung Chang went to Shanghai to attend the opening of the new waterworks that was to give the city pure water, in place of the filth-laden ditch water that had proven fatal to so many foreigners, he announced on taking a drink from the new supply, that it lacked body.

An Awful Immersion.-One day a very fastidious missionary lady was riding a gentle old horse near Seoul, with a native girl seated behind. In turning out from the road near one of these great receptacles just mentioned, the horse lost his footing and his rear quarters slowly slid into the pit. The two poor females went off backwards over their heads in this awful mire-and they were miles from home.

House Snakes.-The thick layer of earth under the roof tiles of a Korean house makes a nice place for the innumerable sparrows to nest. The birds and their eggs in turn attract rats and house snakes, the latter being a harmless variety about three feet long and as large as one's arm. Since the snakes destroy the rats and help to keep down the sparrows, they are not molested unless they chance to make a mistake and drop through into a room. Such an occurrence is regarded as being an ill omen and when it occurs at the palace the whole building is abandoned.

I knew of an English missionary lady who chanced to turn over her pillow as she was about to retire to her cot on the warm floor of a native house in the country, and there she saw one of these large house snakes comfortably curled up. 
Another lady went to her flour barrel in a dark storeroom and finding something soft on the lid she investigated and saw a snake coiled all over the circular space of the barrel cover.

On bright warm days in the spring these snakes often come out upon the roofs to sun themselves, where they are soon discovered by the sparrows that regard them with just hatred, and they begin a most excited chattering and dashing at and about the snake. Messengers fly off and collect companies of the valiant magpies that certainly do enjoy a fight, and they soon drive the snake to cover by their vicious pecks.

Magpies.-A Korean house would not be complete without its sparrows and magpies,--those friendly birds that seem to go wherever man goes in that country. They seem to dislike cats as do the Koreans and the magpies particularly will attack a cat on sight. It used to be amusing to see a young and venturesome foreign cat try to stalk a magpie, to the evident delight of the latter who would surely lead the cat on until in good position away from the house, when the bird would turn and before the cat knew what had happened fur would be flying and he himself would be dashing for safety under the house. One such encounter was usually enough to teach a cat caution.

These impudent birds are very inquisitive and seem to have quite a sense of humour. In Nanking they seemed unable to comprehend the meaning of our glass windows, yet they could not give up trying 
to see what it was that prevented their passing through that particular space. They would cling to the sash and beat at the glass with their bills till it seemed they must break either one or the other. They seemed much amused with a row of fine tulips in our garden at Seoul, and numbers of them would blacken the legation lawns taking their turns in running up and pulling out a tulip leaf. Shooting at them afforded only temporary relief, so a few of the dead birds were planted in the tulip beds with the bills and wing tips protruding from the ground. This brought on a careful investigation, with much chattering and preening of necks, after which they all flew away and the grounds were deserted by magpies for some time thereafter.

On one occasion I put out strychnine in meat to kill some abandoned cats that occupied the gable of a deserted house near where we were then living. Some magpies got the poison and flew up into an ancient gnarled tree to devour it. After a time one suddenly dropped to the ground and fluttered for a while, causing much consternation on the part of its companions, some of which walked about the prostrate form while others flew off calling shrilly and collecting numbers of other magpies. Soon the little yard near us and about the old tree was black with the birds, seemingly very intent upon watching two apparently old ones, that appeared to be holding a consultation over the dead bird. It was all so humanlike that it made me feel creepy as though they might pronounce me guilty of murder. Finally the two old 
birds took the prostrate one by its wings and tried to fly up with it but with no success; the poor thing fell back with a thud. While this was going on another bird fell to the ground, and then a third, whereupon as with one accord they all flew away and no magpies seemed to light on that tree thereafter.

A Devil Tree.-Incidentally this served us another good purpose, for a native family were in the habit of assembling in the space under that ancient tree to hold their nightly lamentations for a recently deceased member of their family. As it was just across the wall from our bedrooms this wailing had become most distressing to us though we saw no way of interfering with it. When it became evident to them, however, that the old tree was possessed of certain devils of such malignancy that a bird alighting upon it, or a cat climbing it, would be struck dead, the family made their lamentations somewhere else and even walled in the space under the tree lest some child go there and be seized by evil spirits. Thus were we relieved of cats, mourners, and magpies at one and the same time.

Rats.-Rats are a great nuisance in Korea and if plague should ever be introduced into the land and spread to the rats its ravages would be awful to contemplate. The destruction of property by these vermin is so great as to be quite beyond the comprehension of the ordinary native who would naturally think so small an animal could not eat very much, forgetting what millions might do; thus they take no measures to rid themselves of the pest. 
Rats Like False Teeth.-The nimble little thieves will take almost anything moveable. Once they stole a new set of false teeth from a missionary who had gone to Japan to fit himself out with this convenience. Returning on a native steamer, he lost his teeth which were finally found, after much hunting, in a rats' nest inside the walls of his cabin.

Rats in Ceilings.-They will tear off the upper surface of the paper ceilings to get the flour paste with which the layers of paper have been applied. In stripping off this taut paper it makes a noise like the beating of a drum. I well remember my first experience with this noise. I had just landed in Seoul and was spending the night in a native house with my Chinese attendant. We had no beds, but slept on the floor and as I was using my shoes for a pillow, sleep was perhaps not very sound, at any rate we were soon brought up wide awake by what seemed to be the roll of a drum close at hand. We got the natives up and my Chinaman wrote to them in the character telling them of our trouble, at which the men smiled and explained that it was simply the rats, showing us how to strike the paper ceiling with our hands to drive the animals away. After that we spent much of our time hitting the ceiling.

Cats.-I afterwards secured a foreign cat from one of our ships and established a fine breed of cats that soon rid our own house and the houses of our friends from the plague of rats.

Cats are not very common and are not made house pets as with us. Some of the natives have as 
great an antipathy to them as we have to snakes. Twice have I seen high Korean officials faint at dinner at a foreign legation when the family cat accidentally strayed into the room. One of these men who was sitting next to me on one occasion suddenly pitched over, his wide hat brim upsetting his glasses, while his face fell in his plate. I carried him out and as he revived in the air he exclaimed the native word for cat. A kitten had strolled unobserved into the dining-room, and as the Korean was sitting where its mistress usually sat, the kitten climbed the ample gowns of the Korean and ensconsed itself in his lap. Imagine looking down and finding a snake curled up in your lap at a dinner table in some strange place and you will appreciate how the Korean felt.

\section{Hospitality}

The Koreans are a very hospitable people. Formerly there were practically no beggars in the land, but after we had maintained marine guards at the various legations for some time, the practice of the generous sailors and marines of throwing coins to the street urchins, served to raise up quite a company of mendicants.

Guards.-These guards were a source of great interest to the natives, particularly at the hours of their meals. There were always numbers of hungry native boys on hand to eat up the scraps, and the American guard was most popular on such occasions because of the extensive and generous menu they 
enjoyed. The Russians lived largely on rich vegetable soup and black bread, while the French also consumed much soup. The Americans however had plenty of meat with puddings and other dishes containing sugar. The natives declared that the American guard lived like yangbans (officials), while the others were the sangnoms or common people.

China's Beggar and Thief Guild.-In China the beggars are regularly organized in guilds with welldefined districts wherein their business may be prosecuted. Residents make regular contributions to these guilds and thus secure immunity from annoyance. The same is true of the thieves who are organized in guilds and any one contributing regularly to the guild is undisturbed, while if he should lose property by theft it is recovered for him, since theft in such case would be an accident.

Korea does not have such guilds, which is sometimes regarded as unfortunate. Ancient China has in fact profited much by the experience of centuries and in cases where a human frailty is beyond correction they take measures to protect themselves against an undesirable manifestation of such failing.

Kind Reception.-We were greatly pleased with our reception in Korea. Our residence in China had shown us that foreigners were not wanted in that country where we went by the name of foreign devils, and were visited with a sort of vicarious punishment for the treatment bestowed upon the socalled "Chinks" in America.

In Korea on the contrary, we were treated with 
the respect shown to the official class. Instead of having the dogs set upon us as in China, when a dog rushed out to bark at us some Korean would promptly call him off, while instead of being jostled or ill-handled in a crowd, a way would always be opened for our passage.

A Stoning.-Once in Nanking I went with a sturdy old missionary to see the great competitive examination, where thousands of aspirants for rank and position were seated in little booths in the great examination hall grounds, engaged in writing essays on the classics, while thousands of sightseers surged through the passages.

An old beggar woman who carried a little fire pot, was pushed against me by some rowdies and her pot dropped to the pavement and was broken. It was worth a few cents and we were as anxious to pay as she was vociferous in her demands for payment. We had no small money, however, and my friend tried in vain to satisfy her by promises. The crowd took up the matter and we were roughly handled. Failing to get any protection my friend, who was no coward and had a bullet in his leg as a relic of valiant service in the navy during our war of the rebellion, announced that we would have to run for it. The old bullet prevented him from doing much execution as a runner, and soon a paving brick which struck me in the side reduced my wind so that I was in little better shape. By cutting across lots we finally reached home and got a message to the magistrate which prevented further trouble. 
Vicarious Atonement.-The Chinese have a very clever method of meting out justice in such cases. Once when living beyond the native city of Shanghai, we were riding along the road outside the city wall, on our way to the foreign settlement. We were seated on either side of a passenger wheelbarrow, the wheel coming up between us in a frame which served as an arm rest. Some men on the wall began abusing us and calling us foreign devils, and as their courage waxed with their efforts, they began stoning us. Maybe one of them had been to America and had received similar treatment for which he was now getting even. Arrived at the settlement a friend, to whom I related the incident, took it to the native official, who called up the head man of that ward and had him flogged; he passed on the punishment to the head man of that group of houses, and this dignitary in turn punished those under him until the proper man may have been reached. We were never afterwards molested at that place.

A feeble imitation of this sort of vicarious punishment is practised in Korea, but it seems not to be so well understood as in China and is therefore not so effectual.

Burdensome Hospitality.-Hospitality among the Koreans extends to comparative strangers. I remember being at the house of a native friend at about the time of the morning meal, and noticing many tables of food being taken in to his guest house, I asked if he were entertaining company, whereupon he let me look into the room which was 
filled with men sitting on the floor, each with a table of food before him. He explained that they were men from the country who had come to Seoul on business, and those who did not know him knew some acquaintance of his which gave them an excuse for calling and then for remaining and eating his food.

This is one of the burdens of the well-to-do in Korea. When prosperity comes to a man, relatives whom he may have never seen, come to live on him and bring their friends. This has its compensations, however, for when a man's house is so sought by numbers it is an indication that he is prosperous or has influence at court. These companions of prosperity soon take their leave at the first rumour of a change in fortunes, for in case some enemy has succeeded in undermining their patron at court, his arrest may be ordered, in which case the hangers-on may sometimes be made to suffer for their friendship. So as long as the horde remains it is a good indication that prosperity is smiling upon that particular house.

\section{Food}

Rice.-Rice is the chief article of diet, being eaten dry with no salt or dressing. Beans, and noodles made of flour, are also much used. The meal is served on little individual tables a few inches from the floor. There may be soup, fish, meat and relishes, in addition to the rice, beans or noodles, but the chief article in the way of vegetables is a salted 
cabbage or turnip, which supplies the salt needed for the tasteless rice.

Kimche.-This salted vegetable, called kimche, is prepared from cabbages or turnips as the foundation, mixed with red peppers, oysters, oil and garlic, all put down in brine and allowed to ferment for about two months. There may be as many as one hundred and forty ingredients in the mixture, which is packed in great earthenware kangs the size of a barrel. When ready to serve it is crisp, and when made without the garlic, it is simply delicious. I seem to have been one of the few foreigners who took to this article of food and I always had it put down for winter consumption minus the garlic, which deprived it of its objectionable odour.

The odour of genuine kimche in all its strength is something remarkable. I can best describe it by giving an account of my introduction to it. This happened in the early days, when I was conducting a hospital where neglected cases were plenty and bad odours were very common. Entering my home office one day I was met with a most penetrating smell such as I was not apparently acquainted with. Calling the servants I remonstrated with them for allowing patients to come there when they were under instructions to send them to the hospital. They declared no sick people had been admitted and when we entered, after opening the windows, to make an investigation, we found the odour came from an unsuspicious looking little jar left there by a grateful patient. 
It was a jar of the ripest and rankest of kimche, which was at once ordered to be thrown out. From the perfumed breaths of the coolies, thereafter, it was evident they appreciated it even if I could not. Later I was induced to taste some of this compound made without garlic and it won me at once, leaving a memory that haunts me pleasantly still.

Odours.-After all, the effect of various odours is largely a matter of education. The stifling smell of the sulphurous and tarry soft coal smoke poured forth by the steam locomotives positively alarms the Koreans. It seems to them to be a deadly poison. The odour of our ripe cheese is another that a Korean cannot accustom himself to. That delicious fruit, the durian, to be had at Singapore, is so very offensive as to cause many travellers to lose the opportunity of enjoying its rich pulp, while the natives think nothing of its odour. The odour of kimche is most agreeable therefore to the Korean, who would turn positively sick upon smelling limburger.

Milk and Sugar.-Speaking of cheese, it is remarkable that in Korea where are to be found such fine large cattle, there is no use made of milk, and this too in a land of such poverty that it would seem that all proper foods would be cherished as such. True they know the use of milk, since children, invalids and the aged use human milk, but the milking of cows is not practised by the people. Of late they have taken to the use of our sweet condensed milk, through the recommendations of the foreign physicians who have prescribed it for children. There is 
now quite a trade in this article, which the people like because of its extreme sweetness-in a land devoid of sugar, except the sweet of honey, and that obtained from rice and similar grains. An American living at the gold mines, made some excellent maple syrup from the native maples growing there, showing that the poor natives have neglected some splendid opportunities right at hand, notably milk and sugar.

A Food Maxim.-The Korean habit of making up the food into little pats or boluses, easy to handle with chop-sticks, using their not overly clean hands in the process, causes the initiated to care little for sampling native food except such as is handled in bulk, like rice or kimche.

The natives themselves are wise in this regard and they will quote you a proverb to the effect that he who would enjoy his food should not look over the kitchen wall. This proverb was given by a former king who delighted in slipping out in disguise and seeing things for himself. Returning from a stroll of this character on one occasion, he looked over the wall that surrounded the kitchen area of his palace, and saw the final preparations for his evening meal.

A very dirty scullery maid had just prepared a pyramid of luscious persimmons on a little table. The fruit was dead ripe and the juicy pulp almost burst the delicate glossy skin that held it. The maid surveyed her work with evident satisfaction and stooped to take up the table, when a little whirlpool of dust came twirling along and sprinkled a column of grit all over the fruit, rendering it unfit to place 
before her royal master. The poor creature wept, for she had no more fruit; it was time to serve the meal, and the tender skin of the persimmons would not bear wiping without bursting, and rendering them useless. Suddenly as she stood weeping, a bright thought came to her. She got a fresh table, and, picking up the fruit tenderly, one by one, she carefully licked off each one and set it on the new table all ready for the attendant to take in to the king. Hence the proverb.

\section{Amusements and Pastimes of Old and Young}

Intrigue.-The common people have few amusements. Travelling through the country one often notices at a hamlet two or more men off by themselves engaged in whispered conversation. These men are surely plotting to gain some advantage over another. Entertain an official alone, even in a large room, and he will edge up to you and begin to whisper. It is the same manifestation of the native aptitude for intrigue, which makes them excellent as starters and destroyers, but unsatisfactory as sustainers of an undertaking. It seems that in many cases this tendency is given scope rather for the excitement it furnishes than from pure malice. The villagers schemed against their head man or plotted some charge against a successful neighbour; the court official plead for the influence of the foreigner to enhance his own power at court; in both cases it was the same game of politics in all its petty meanness.

This habit of falling so naturally into intrigue 
might well be the result of the almost utter lack of stimulating amusements. Our own people go to the play and get wrought up over the crimes of the villain, knowing that he will get his deserts before the curtain falls, but the Korean has to act the play himself or lose all such excitement. Naturally he will try to take a part that will be to his advantage.

Itinerant Performers.-Just let a blind singer or a slack-rope performer come along and all these plots will be dropped for the time, while feasting eyes and ears upon the unusual entertainment.

So highly prized are these itinerant displays that when I went with the Koreans in Washington to see one of our great circus performances, they calmly assured me they had the same in Korea. My disappointment at their lack of appreciation of our "greatest show on earth" was so pronounced that, in later years, one of these men invited me to a Korean "show," in order to prove the excellence of their own. It was simply a slack-rope performance in the open, where two men in full flowing robes actually did perform wonderfully well, while thousands of native spectators stood open-mouthed and wide-eyed, wholly engrossed in and completely satisfied with the display of skill. True it was like our performance, and apparently the Koreans preferred it to ours.

A playhouse seemed to be even more needed for the adult poor than schools, since it would give them something to think of and with which to satisfy their craving for amusement, thus checking petty scheming. 
The Theatre--In time a theatre was opened on semi-foreign lines, where creditable sleight-of-hand and slack-rope performances alternated with dancing and pantomime, before large and deeply impressed audiences-audiences that were in themselves most interesting, since high and low sat side by side providing they had the price of a seat. It was a leveller after the style of the trolley car. Even women attended and sat in a portion of the house screened off for their use, gazing for the first time, maybe, at the games that had amused their rulers for centuries, for some of the performers were actors borrowed from the palace, who performed for the people the simple acts commonly given before their rulers.

Palace Sports.-Of course the ruling classes have what takes the place of plays with us, but with the exception noted above, there are no playhouses. The best performances are given at the palace before the royal family and the assembled officials. These consist of dances by the class of public dancing girls or gesang, together with some male country dances with songs. The people do not dance for themselves, but sit and look on while it is done for them.

One dance given by these girls is called the sword dance and is quite rapid and graceful towards the end, usually eliciting considerable praise from foreigners. There is the dance of the storks, in which two men disguised as great storks dance about a large lotus flower, drawing gradually nearer and making many feints at the blossom, until finally they do peck open the pink petals, when out steps a dainty little 
gesang. Tigers, each made up of two men cleverly disguised, do a grotesque dance that never fails to afford a delightful state of alarm to the children. There are dancing and musical contests consisting in rythmic gestures ending in an attempt to throw a silken ball through an opening in an ornamental arch. This is performed by a train of dancing girls and affords great amusement, since the winners get flowers stuck in the mass of false hair which adorns their heads, while those who lose get a black mark on the cheek. Later the ones adorned with flowers are each presented with a roll of silk.

Some such entertainment usually followed the frequent banquets given at the palace to the diplomatic officials by the very hospitable court, and they were always appreciated at first, but by frequent repetition these dances became insufferably monotonous. It actually seemed depressing to think that in all the ages past this had been the choicest amusement possible to the most exalted in that land. It is not strange that they turned to intrigue for excitement.

Gesang.-The dancing girls are recruited from the people. A poor man having several daughters would give a particularly comely one to the government, by which she would be educated in music and dancing and in all the arts of entertaining. She would be well housed and richly dressed and might some day expect to make a conquest of some one of her more eligible admirers, and become the concubine of a man of rank and wealth, for this class to 
women, the only one that mingles freely with men, would not hold strictly to ideas of virtue. The sons of such unions, with the fresh blood from their mother's peasant origin, often outclassed the sons of their fathers by his real wife, and became important factors in matters of state, though not eligible to all the honours possible to the sons of wives.

Eunuchs.-In the same manner a poor man with several sons might give one to the government to be made into a eunuch for service in the palace. These boys would receive the best education possible and might hope in time to exercise a very great influence in governmental matters owing to their proximity to the ruler. I have had some very good friends among this class of men and always found them faithful in their friendships, though undoubtedly they have at times counselled acts that resulted in great cruelty and hardship to the common people from whom they sprang.

In a land where children, especially sons, are so highly prized and where they are so indulged, it may seem strange that parents would care to part with even a daughter and permit her to take up the life of a gesang, much less to consent to the loss and maiming of a son; but necessity assists their philosophy and when the child has attained affluence or power, the parents are sure to be greatly benefited in worldly condition.

Children.--The Korean children are like the young of other lands, except that perhaps they are more generally well behaved. 
Games.-They play games corresponding to the toilsome tasks of their elders. The girls play at sewing and keeping house and at the dreary washing that may soon become their lifelong toil. In imitation of their fathers the boys bear miniature play burdens suspended on poles balanced on their shoulders. Lately the little urchins have taken to imitating the soldiers drilled in foreign style and give the commands quite creditably, even to sounding the bugle calls on little toy horns. They are fond of swinging as are the grown ups, some of the latter being very expert on great swings upon which they will perform with sometimes three men to one swing. The children pitch pennies and gamble as do their elders. They even divide up into rival companies and play at the stone fights for which the country is peculiar.

Stone Fights.-These conflicts among the men are serious and merit a short description.

Two rival villages will assemble on a frozen plain in the early spring and test their relative strength. An advance guard with heads protected by helmets of straw rope, and armed with clubs, will dash at each other across a neutral strip. Then the protecting rear forces rush down the hillside and throw stones at the opposing forces. The chief execution is done with these stones, in the throwing of which the natives are very skillful. As one side overpowers the other and puts it to flight a mad noisy battle takes place, which causes the thousands of spectators, who cover the adjoining hillsides, to surge in panic 
as they flee from the rain of missiles sent by the victorious and pursuing side.

In a real good fight of this character there are usually a few fatalities and many serious wounds. One man came to me in the early days, after one of these fights, with both tables of the frontal bone broken and the brain quite visible underneath. The lads who play at this game do not resort to these extreme measures. Military men who have witnessed these contests, seem to think that a people who go to such extremes in their sports should make good soldiers.

Kites.-Perhaps the finest sport of the Korean boy is kite flying. Their kites are painted squares of paper stretched over a light bamboo frame, with a hole in the centre of the paper. The cord is wound on a reel having a long handle, which reel the boys manipulate with great dexterity, being able to send their kites almost out of sight with a little wind. The great attraction in this sport consists in sawing in two the cord of a rival. When the kite falls there is such excitement in the chase to get it, that even old men catch the contagion and hobble off in search of the unlucky kite,-finders being keepers. Men indulge in this game very generally, using large kites with stout cord on which has been rubbed a mixture of rosin and powdered glass or fine sand, to aid in sawing off the cord of a rival.

Bicycle Experiences.-Korean youngsters are mischievous as well as appreciative. There is a long narrow bridge east of Seoul where it was my custom 
to dismount and put a little chap on my wheel to trundle him across the bridge. It took some coaxing at first to induce these boys to trust themselves upon this strange machine, but when one had tried it and had ridden proudly over, ringing the bell all the way and smiling broadly through the grime on his happy face, there was no more fear. A crowd was always awaiting me after spying me down the road, and several trips would have to be made to satisfy the more clamorous. This resulted in my always having the best of treatment in that neighbourhood where they would actually address me as " excellency,"- - the term used to the aged and to officials.

A Boys' Trick.-Having met with such appreciation at this place I decided to secure the assistance of some boys at a spot not far distant, in fitting up a crossing over an ugly little ditch that compelled a dismount on an otherwise good road. I gave them some cash and they brought tools with which we imbedded a flat stone in the sides of the ditch, covering it neatly with earth and making a narrow path which was ample for a wheel. Coming down the road later on my return I congratulated myself that I would not have to dismount, and took the bridge at a good gait. My front wheel went through and stopped while I went on. The little rascals had removed the stone and put in a bridge of twigs neatly covered with earth. I could not see them but I knew they were looking and were enjoying seeing me limping along home with a disabled wheel. 
Raising the Dead.-The seriousness of life soon claims the native boy. As early as possible, village and country boys are obliged to go out and forage for fuel. The grass and pine-needles are carefully raked up and made into bundles with straw rope by the boys, who carry this fuel home to be sold or for use in cooking the rice twice daily, which heat also serves to warm up the stone floors upon which they sleep.

One spring day I was out in a pretty grove that sheltered a tomb. I was seated behind the grave itself, and hearing some boys beyond I turned to look at them as they raked up the pine-needles. My hat was off, my figure was concealed by the mound, and all they could see was a bald head apparently protruding from the grave like a skull. As they suddenly saw this apparition they gave a scream of horror and fled, leaving their tools, while the smaller ones being outdistanced, howled in despair lest they be caught by the man rising from the dead.

\section{Eariy Railway Experiences}

Childlike People.-The whole people may be considered as children, so childlike are they in many ways. With few amusements and until recently, no newspapers; with plenty of leisure and the habit of not doing to-day that which may be put off till tomorrow-a day that never comes, since when it arrives it is still to-day-these gossipy and naturally curious people are ever ready to hear or see some new thing. 
In I 884 one of our naval officers came to Seoul from his ship at Chemulpo, bringing with him his bicycle which was of the old high wheel type. We went through the crowded main street, he on his wheel and I on a horse. As this appalling looking object came in sight the throngs of people rushed to the middle of the street for a good view, and as it came nearer they fell back in unfeigned astonishment amounting to open-mouthed alarm, as the strangest thing they had ever seen glided through the narrow passage left for it. As the high wheel and its rider passed and was seen to be harmless and simply another of the strange freaks of the newly-arrived foreigner, they actually fell into each other's arms with laughter following the relief to their first surprised alarm.

The Cars.-The steam cars were a source of such interest that a quiet crowd always collected at the stations to witness the coming and going of the trains. The engine was of course the chief attraction and the white-robed, stolid-looking group would surge backward with each toot of the whistle or jet of escaping steam.

The attendants on these trains had hard work to keep the third-class passengers inside and seated. The platforms seemed to offer the greatest attraction to them and the fact that one would occasionally drop off into space in going round a curve, seemed not to affect the others, since the next train would have an entirely new set of passengers.

They would persist in jumping off as the train 
came to a stop as though afraid they might be carried beyond their destination. As they would of course go straight out and then fall when their feet struck the ground, they presented a ludicrous appearance as, with an air of bewilderment and injured dignity, they looked about to see what or who had caused them to fall.

The railway soon became a great educator. The trains would not wait even for a noble. If one such sent word he was coming and arrived in the afternoon for a morning train, he would invariably find it had gone off and left him. Trains have even pulled out on schedule time with some great yangban coming down the street with his chair men on the run and his attendants well ahead shouting "yahbo, yahbo come on yeetso" (say! say! wait a little), to all of which the engine seemed oblivious.

So with the electric cars, which also would not tarry at the demand of the attendants of one of the gentry, and even when the great man himself would simply stop at the car steps and give some orders to his menials, the impudent contrivance was likely to go off and leave him standing there in the road.

Street-Car Accidents.-The lesson of punctuality was not the only one taught by these modern methods of transportation. Passengers in time grew to understand that they must stay in their places, though this was a hard lesson to learn. One day as we were riding near the East Gate at full city speed, the hat of a coolie became loosened and blew off. Without a moment's hesitation the fellow jumped right out 
after it, struck on his feet first, and then on his head, where he twirled around on his knot of hair, like a boy's top, and fell with his neck broken.

Considering the crowded condition of the streets there were comparatively few casualties but when such did occur it usually meant prompt trouble with an ugly mob, the destruction of property, and the interruption of traffic. One intelligent native magistrate in rebuking some rioters, explained to them that the cars would not leave their tracks and chase people, and the very fact that a person had been struck by a car showed that such person was in the wrong by being on the tracks in disobedience of regulations.

Tracks as Bedrooms.-One of the strangest difficulties the street railway people experienced was due to the fact that the native poor insisted upon using the tracks as a sleeping-place on warm nights.

The Asiatics do not use a soft pillow such as we employ, since that would disturb the hair, which in China and Korea, as in feminine Japan, is put up with great care and some expense, and is expected to last several days. A hard frame of wood is therefore used, on which the neck rests. A tomato can affords an excellent substitute for a pillow for the poor man.

The cool iron rails, so neatly shaped in regulation pillow pattern, seemed just suited for use and were quite alluring on a hot night, so spreading their mats on the smooth cinder tracks the people would pillow their necks on the rails in perfect position for decapi- 
tation, quite positive that no car would dare run over them, since any vehicle ever before heard of in Korea would surely stop for a sleeper in the road, and either go around or awaken him. Perhaps they considered that the last car had gone by for the night, if so they miscalculated, for on several occasions a car rounded a curve in the dark and was unable to stop before intruding on a bedchamber of that character and decapitating several sleepers. Even in these cases trouble would follow though none but the aggrieved were to blame.

Large Cars.-Owing to the fact that Americans built the first railroad in Korea, the standard gauge is used and the cars are large and heavy like our own. This delights the Japanese who come to Korea, and causes much regret on their part that they have not the same in Japan, instead of the little narrow-gauge ones. Some of the passenger cars in Japan, even on such long routes as from Tokio to Kobe, are like our old-fashioned street-cars; long seats on the sides; too low for a tall man to stand up in with comfort; windows that open like the old street-car windows and consequently most drafty on the passengers' backs, and such continual rattling as to cause one to fear the early falling to pieces of the whole structure.

Horror of Night Travel in Japan.-Of all horrible railway experiences the night ride on the government railway between Kobe and Tokio is one of the worst. In order to get one of the little cells in the corridor cars, four full first-class tickets covering transporta- 
tion and sleeping car, must be purchased. Then the little coffin-shaped berths, which are but very narrow shelves, are fixed and the upper one cannot be put out of the way. The window is small, high, and useless for ventilation. In winter one will be either roasted or frozen, while in summer the place is after the style of the black hole of Calcutta. Electric fans have now been introduced and are guaranteed to bring on pneumonia in one night if put into service, for all the bedclothes are sewed up together in a sort of bag, preventing one's getting some light covering, while the whole tick full is heavy beyond possibility of use. This is on the government railway; there is a private road running from Kobe to Shimonoseki, which I am told is a great improvement on the former. Government ownership seems necessary in a land of so few fortunes and of such poverty of the masses, but in actual working it leaves much to be desired.

\section{Servants}

One of the chief compensations of life in the Far East is the abundance and cheapness of domestic help. As house servants the Koreans are not equal to the Chinese, who make that calling a profession and regularly learn the business, which they transmit to their sons in many cases, making it a life-work and acquiring the arts of fine cookery and of butler service most admirably. A very efficient head Chinaman in our employ for many years, made fine candies of such excellence, that visitors from home could 
hardly be persuaded we had not some private way of getting these sweets direct from one of the chief manufacturers in America.

A Korean is apt to tire of such steady duty, and on getting proficient he will probably go off and start a little shop for merchandizing, only to return and relearn housework after he has "eaten his shop."

Quaint Mistakes.-Our ways differ so greatly from their own that native servants sometimes find it difficult to comprehend just what is wanted, as was seen by a lady who wished to catch the flies in her kitchen after the screens had been placed in the windows. She gave the cook some fly paper to use for that purpose and on going to the kitchen later she found - he had removed the screens and hung the paper in the windows so as to catch more flies.

A Cocktail.-One of my predecessors at the American Legation once had a couple of callers at his office, which was some distance across the grounds from his living quarters. Wishing three cocktails with which to refresh his guests and not caring to spare the time necessary for sending for his "boy" to come down and get the order, he simply wrote on a paper "bring three cocktails," as the servant had a working knowledge of English. The Chinaman knew the name of this drink when spoken, and could compound it, but he did not recognize it when slowly spelled out from a written "Chit"; he therefore resorted to his dictionary, with the result that after much delay, during which the entire servant staff was out chasing 
the fowls around, he came in perspiring and delivered three tail feathers from a very indignant rooster.

I know this story has been told in other connections and I see no reason why it may not have actually occurred several times, but I am sure this particular incident actually took place, though I was not present as a witness.

\section{MarRIaGeS AND FuneraLS}

Love.-Such affectionate demonstrations of tender sentiments as is approved of and appreciated by us, in the bearing towards each other of married couples or those about to be married, would be considered indelicate if not shameful by an Asiatic, if indulged in by one of his own people.

Love as we understand it is apparently supposed not to exist, or to be carefully concealed if it does exist.

Marriages there are in plenty, but these are arranged by the elders and go-betweens, with the result that spinsters are practically unknown, and bachelors are rarely met with.

Manhood.-When a boy is betrothed as he must be sooner or later, he need no longer wear his hair hanging down his back like a girl, making it difficult for the stranger to distinguish between the sexes. His hair is then put up in the topknot of which the native is so proud, and of which the Japanese are said to be trying to deprive them, thus repeating one of their silly blunders of 1894 . With the hair standing erect in this proud knot, the lad is thereafter treated 
with respect, which increases as he puts on more of the attributes of manhood.

Never to have been married deprives a man, however old, of the customary respect due a man. He is not a man but a boy. He must wear his hair, even if it be gray with age, hanging down his back in a braid, and even children use low forms of speech to him. I have met one or two of these poor fellows occasionally, on the road, and they seemed to feel very lonely and friendless; possibly their early betrothals may have been broken by death, and further calamities may have prevented any renewal, until the lapse of time and continued ill luck had made it impossible or impracticable to take on this particular manly attribute, leaving them stranded as boys on life's pathway, with the sad prospect of having no sons to keep their graves green.

Courting.-There is none of the courting such as forms the pleasing prelude to marriage with us. All the marriage arrangements are made by the elders and a go-between. The bride and groom only see each other when all is completed, therefore it often happens that a man actually prefers some gesang or dancing girl (corresponding to the geisha of Japan) whom he has seen and of whom he has become enamoured, in place of the wife selected for him and who may not possess the charms necessary to captivate him. His concubine may therefore have his real affections, but her sons do not take rank with the sons of his real wife. Thus there are compensations, in a land where a woman's proudest boast is that she has 
borne a son, and where she becomes known from that date as the mother of so and so, instead of being a creature without a name known to outsiders.

Betrothal.-During the period of betrothal various visits are exchanged, but these are between the young people and their elders instead of between the young people themselves. All the while the bride's trousseau is being prepared with great care, and an expense dependent upon the ability of the parents and the arrangements of the marriage contract. On the occasion of these visits the bride rides in a carefully closed chair with a leopard skin thrown over the top, while the groom when going upon such an errand is mounted on a gayly-caparisoned horse. Each of course is attended by maids or men in numbers corresponding to their social position.

Marriage.-When the final day arrives the frightened young woman travels to the home of her intended, into which she is to be absorbed as one of his mother's inferiors. She goes in a chair ornamented with red and covered with a leopard skin, preceded by a procession of women servants, bareheaded and adorned with the most wonderful masses of false hair, on which rest red wrapped packages containing her trousseau and presents.

One of the presents exchanged is a goose, the emblem of conjugal faithfulness, since the goose is reputed to have but one mate.

The ceremonies consist in much bowing, the drinking of the contractual cup, some horse play and chaffing of the groom and the final unveiling of the bride, 
who must feign much backwardness and diffidence towards the approaches of the young man. The bridegroom will have gone to the bride's house to escort her to the home of his parents where the ceremony takes place. During all this time, however, the girl, with her face powdered quite white, will have had her eyes sealed so she may not see, supposedly. She may be but a mere child, in which case marriage relations are not assumed until she becomes older, sixteen being an acceptable age for a girl and about eighteen for a boy, but this often means a year or two less because of the native manner of figuring the age; for instance, a child born on the last day of the old year would be practically two years old the next day.

One of the duties of our young lady missionaries is to find suitable husbands for the young girls in their schools and to stand in the relation of parents to them. Of course they give to the ceremony something of the refinement and solemnity that attaches to our own, and some of their experiences are very amusing.

Pageants.-A wedding procession takes precedence over all else on the road and even a common man may ride in the presence of a great noble, if he is on his wedding journey.

While an official wedding procession is quite an elaborate affair when the gentry or even royalty itself is concerned, yet the greatest of all spectacles the Korean might witness in the old days was when his ruler made his stately progress through and beyond 
the city gates to worship at the tombs of his ancestors; or greatest of all, when he or she was borne in gorgeous catafalque on scores of shoulders, and accompanied by a monster procession, to the final resting place as described in the chapter on a royal funeral.

Funerals.-Ordinarily funerals are held at night and exit from the city of Seoul was by one of two gates located on either side of the city. Money is often spent on these occasions in excess of the circumstances of the family. In the case of a person of standing and wealth, there may be months of delay during which the astrologers busy themselves in the selection of a propitious date for the interment, and a suitable site, in case the family site has not already been selected.

In such cases the procession will be most elaborate, consisting of the bier, white clad mourners in chairs covered with white, hired mourners-male and female, mounted and on foot, and numbers of men bearing red lanterns. The mourners keep up a loud perfunctory chant as the procession wends its way to the gates and beyond.

The poor have to do with much less display, of course, and their graves are located as near to the city as possible in order to save the expense of a longer journey; some of the bare hills about Seoul are so dotted with the graves of the poor as to resemble the face of a man badly pitted with smallpox.

Graves and Haycocks.-We had lived for some time in Nanking with similar hillsides in full view, 
all studded with the little grassy mounds that marked the last resting places of many Chinamen, when one day my wife remarked that she could not understand why those people did not take in their hay which had been in those haycocks ever since our arrival. She was from the country and I disliked to explain to her that she was living in a cemetery, and that those green mounds represented the work of another harvester than the ones of whom she was thinking.

Homesickness.-An American going to Asia to live misses the familiar sights of every-day life. The people and the language are of course strange to sight and hearing. The animals are even peculiar. In Japan the cats have no tails, in China the cows are a sort of water buffalo, in Korea there were no wheeled vehicles except the great clumsy bull carts, and freight was carried by pack. The houses were concealed by a wall, and when entered there was nothing familiar about them. In China, when the temperature fell and the damp cold became most penetrating, it used to be positively depressing to think that all those masses of shivering men and women had no warm place to go to, but must simply content themselves with crouching down in their cheerless houses with all their available supply of clothing added to keep in the body heat, since there was no other to be had.

At Nanking, we could see in the distance, through a clump of trees, what looked like a great red barn such as we were familiar with in Ohio. This was absolutely the only familiar sight in the whole land- 
scape and we carefully treasured the allusion, not going near enough to it to have the agreeable impression dispelled, for I knew it was simply a huge temple with plaster walls coloured red. After a time, however, all becomes familiar, and strange sights are seldom noted except when some newcomer calls attention to them. Twenty-five years of such life makes the surroundings of an Asiatic home as familiar and homelike as are those, for the absence of which so many succumb to homesickness in the early days of their life abroad.

\section{Game}

Our market in Seoul was abundant in game; pheasant, duck, geese, snipe, hare, venison and fish abounding, with occasionally wild boar and the turkey-like bustard. The beautiful Mongolian pheasant was about the most common of this game supply.

Geese and duck were formerly so abundant that I have seen the river fairly black with them, and some of our people have killed four with one shot.

Goose Names.-A colleague of mine had as butler at his legation, a Chinaman who had some original names for things. For instance, he distinguished between the wild and tame goose by calling the former the fly-away goose, while the latter he spoke of as the sitty-down goose. His nomenclature was so very expressive and quaint that my friend forebore from correcting him.

Tigers.-The natives managed to kill quite a number of tigers as was shown by the fact that skins 
were formerly plentiful and cheap. I once bought as large and fine a skin as I have ever seen, for ten dollars of our money, but prices have risen so now that the same skin could not be had for ten times that amount. These are the same as the Siberian tigers and the hair is therefore long and the markings excellent. The leopard is just as popular with the natives for its skin, which forms a part of the furniture of every official who can afford one.

The tiger bones are used as a strengthening medicine as are the bones and horns of the deer.

Picturing a Tiger.--Some foreigners have been drawn to Korea for the tiger shooting. One such I assisted in his preparations and he brought his skins to show me. He had very good success, owing I think largely to the fact that he could adapt himself to native views and conform to native customs. $\mathrm{He}$ gave his hunters money for a preliminary sacrifice to the spirit of the mountains and incidentally for a feast, since that was the ultimate object of the expenditure. This resulted in inducing them to act excellently as beaters.

With the assistance of these people he one day located a great tigress near a mountain top where, on a place from which the snow had melted, she was playing with her cub. Calling off his beaters my friend carefully worked himself around so he had the wind in a right direction and then stalked up to a stone, which he afterwards found was but thirty feet from the tigress that had fallen asleep; he carefully photographed the animal first and then shot her. 
A Woodman's Dilemma.-A Russian naturalist was once tracking a tiger and came upon the animal one snowy morning just as she was about to spring upon an unsuspecting Korean engaged in chopping wood. The Russian had followed the beast by its tracks in the snow up a ridge, and as he came to the top of the incline he espied her across a gully lashing her tail in preparation for the final spring upon the unsuspecting native. With a well-directed shot he broke the animal's neck and it rolled down towards the terrified native. As the latter started to run he had his first glimpse of a foreigner standing opposite with a smoking gun; the poor fellow was so overcome that he sat right down in the snow and called upon the spirit of his maternal ancestor as though fate had him in its grip,-a tiger on one side and an armed, uncouth being on the other.

A Close Call. - The first amputation I performed in Korea and necessarily the first of all such operations there, was cutting off the arm of a native who had been attacked by a tiger. The bone of the arm had been bitten through just above the elbow and the flesh was gangrenous. $\mathrm{He}$ made a good recovery, however, and was quite a wonder to his friends. He had escaped alive from a tiger and a foreign doctor, but would have to go to his ancestors without his arm.

\section{Holiday Observances}

New Years.--The great Asiatic holiday comes with the new year season. Like the Chinese, and 
the people of old Japan, the Koreans give themselves up to feasting and enjoyment for some days following the advent of the new year. Gifts are presented, especially to the young, calls are exchanged and much food and wine are consumed. Every one who can afford it dons new clothes at this season and all possible labour is avoided. The children look forward to this holiday with the same delightful anticipation that our own youngsters experience at thought of Christmas, and the quiet streets of Korean towns are made brilliant at new years by the brightly coloured gowns of the children. All debts are supposed to be paid with the close of the old year and great is the scurrying about to secure payment of obligations as the year draws to a close, though the Chinese, with their excellent business habits, are more exacting in this matter than are the Koreans.

Burning the Hair and Nails.-A nother duty that comes with the end of the year is the destruction of all combings of hair and clippings of nails. These have been carefully preserved during the year together with the hair shaved off from under the topknot, and at sundown of the last day of the old year, these relics are carefully burned in order that they may not fall into the hands of some evil disposed person, who might work a spell upon the former owner through the use of these remnants of his physical make-up. Passing along the silent streets at sundown of the last day of the last moon of the dying year, little fires may be seen in front of each house 
where the hair is being personally burned, as is well attested by the odour.

New Moon.-On the fifteenth of the first moon occurs the great festival of the first full moon, which is heralded as it rises over the surrounding mountains, by numerous fires on the hillsides in honour of its appearance. Due attention to this first full moon is supposed to insure the observer against ill fortune during the remaining months of the year, of which there may be thirteen in some years when it becomes necessary to add an extra month to take up the accumulation of days.

Thirteenth Month.-The presence of this intercalary moon sometimes works more or less havoc. The people plow and sow, cut their ice and lay in their winter's fuel, by the phases of the moon, but when an extra moon in the early part of the year throws their planting some thirty days late, awkward results are sometimes experienced at harvest time.

Walking the Bridges.-At the time of this first full moon the people come out into the moonlight and celebrate the custom of walking across the bridges, in order that they may be spared disease of the legs or feet during the ensuing year.

Bad Luck Images.-This is also the night for warding off ill fortune in still another manner, which is by the ceremonial transfer of any bad luck that may be hovering about before descending upon an individual, to a little straw image made in human shape. The man will place cash where the eyes should be on the image and then lay it out on the 
roadside. Some poor outcast whose luck is so bad that it cannot well be made worse, will take up the image to get the coin for a drink of wine, and thus the bad luck is transferred to him.

Annual Bath.-On the third day of the third moon all careful people take a bath in order to wash away certain impending trouble and prevent its return during the year.

Cold Food Day.-At the end of the third or the beginning of the fourth moon comes the festival of "Hansip" or "cold food day." On this date no fires are kindled and all food must be taken cold, because of the belief that in ancient times, on this day, an aged Chinaman upon whom official rank was forced against his will, committed suicide by burning himself to death. That a man should be so self-denying as to refuse official position was such a marked act of abnegation as to be thought worthy of perpetuation in legend and festival.

Buddha's Birthday.-The birthday of Buddha is celebrated on the eighth of the fourth moon by a great display of coloured lanterns and fires. Further, every house wherein a son has been born during the previous twelvemonth, displays enormous paper fish suspended from tall poles. The mouth of the fish is kept open by a ring, allowing the air to circulate freely through the image, which is thus blown out and distended as the great highly coloured figure floats gracefully in the breeze.

Swings.-The fifth day of the fifth month ushers in the season of the swing. At this time strong 
swings are suspended from suitable trees, or if no suitable tree is at hand, massive frames are erected and topped with boughs. On these swings several men will at times perform together. The observance of this custom is supposed to mitigate some what the plague of mosquitoes during the ensuing summer.

Advent of Rains.-As in other lands dependent upon the timely appearance of a regular rainy season, the advent of this vitally necessary forerunner of the harvest is appropriately celebrated. This is at the festival of Ching Yuh and Kyain Oo. These were mythical beings supposed to be attendants upon the "King of Heaven," who neglected their duties in order to spend their time together as lovers, for which neglect they were banished to opposite sides of the heavens as stars, and only allowed to meet once a year, when on the seventh of the seventh moon, they reach either side of the heavenly river (milky way). The friendly crows then make a bridge over this river and the lovers cross on the heads of the crows, as may be seen by the fact that the crows are bald (moulting) at that time. The almost immediate parting causes these lovers to dissolve in tears which fall to the earth as rain. If this meeting fails, a drouth ensues with famine and starvation. ${ }^{1}$

The native girls are given presents of threaded needles at this festival, as an admonition to them to

1 This folk tale, with others, is elaborated in my "Korean Tales" and my "Korea-Fact and Fancy." 


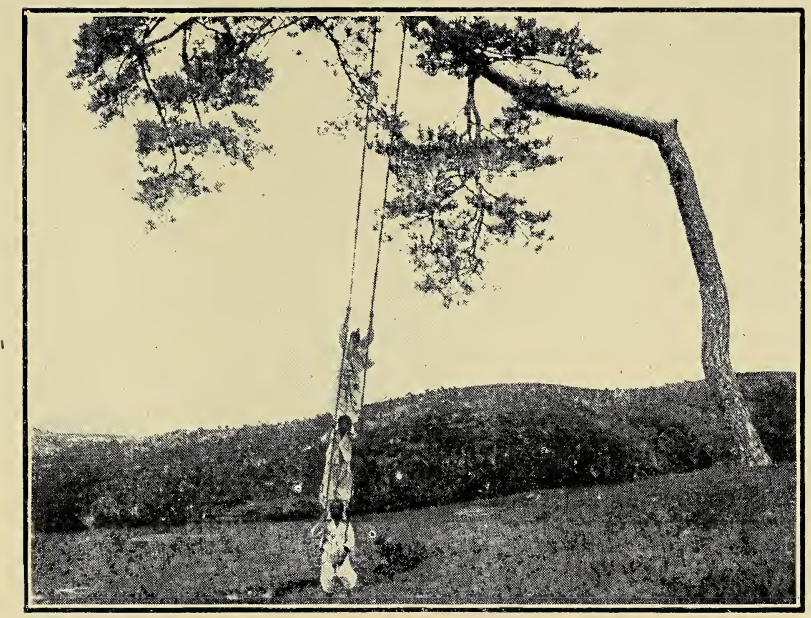

THREE MEN STINGING

A Cure for the Mosquito Plague



BULL LOADS OF WOOD FOR SALE 

be busy and industrious in attending to their duties that no such fate may befall them as that which befell the neglectful maid in the heavens.

Dragons.-Korean superstitions surround almost every act of importance. The very cities are surrounded and protected by the superstition of the dragon which is outlined in the enclosing hills and ridges. Much difficulty was experienced in building railways in China because of this superstition, while in Korea foreigners have had difficulty in erecting houses lest they disturb this sleeping dragon. 


\section{A ROYAL FUNERAL}

THE Queen of Korea, who was given the posthumous title of empress, was assassinated by Japanese and Koreans on October 8, I895. Her body was burned in order to conceal the crime and only a small bone was recovered. This much of her remains was, however, buried in state.

Several locations were selected for the cemetery, one of which received considerable preliminary work before it was found that the site was not propitious from an astrological standpoint.

A tract of something over one thousand acres was then taken, lying near the walls of Seoul and including mountain, hill, level rice-field, village and stream. All habitations were removed, tens of thousands of young trees were set out and large sums of money were spent in making this a beautiful park for the future.

In time the interment took place. The grave itself surmounted an artificial hill of about forty or fifty feet in height, which was anchored to the natural hillside. The grave proper was encircled by a carved balustrade of stone, while various stone images stood around and at the sides of the grave mound. There were the tiger for protection, the sheep for sacrifice, 
the torch on its pedestal and the snug looking priest. Before the grave there was placed a splendid block of polished marble serving as a table for sacrificial offerings, and in front of this came the elaborately carved stone lantern, similar to those common in Japan, copies of which are now sometimes seen in fine gardens in America. All these stone figures, with the grave itself, did not crowd the ample summit of the grassy artificial hill.

Mortuary Parks.-It should be explained in passing, that the country surrounding Korean cities, and to a certain extent the country generally, is made beautifully picturesque by these burial spots or cemeteries. A clan, even of little consequence, will set aside a hilly region near their village for their burial ground. Here the trees are carefully preserved and the grass is kept in order by the faithful descendants, to whom filial piety and reverence of ancestors amounts almost to a religion.

Such being the case with the common villagers it may well be imagined what magnificent parks are to be found where the nobility have buried their dead.

The environs of Seoul are made surpassingly beautiful, once you leave the dirty roads, by a circle of these quiet secluded burial parks, each with its artistic temple-like building for sacrificial purposes, standing just below the hill on which rests the tomb proper. A whole valley is selected for the tomb of a royal personage so that no other grave, and no habitation, may overlook it or disturb its solemn repose. 
Each such reservation has a good house for its official keeper who sees to the culture of the shrubs, the care of the trees and grass, and keeps the walks and grounds in order. There is always a stream gurgling through such secluded valley, with artistic bridges of carved stone spanning it. Well-kept paths lead about under the trees and through the tall tori, or gate-like structures, with which travellers to Japan are now familiar.

We took much of our recreation in these quiet, restful parks, where the only other intruders seemed to be the bands of women washing clothes in the brooks. One such mortuary valley was but ten minutes' walk from the American Legation and was a place of almost daily visit by my family and myself, yet we have taken with us to this place, friends who had lived years within the walls of Seoul, yet had no idea there was such a spot so accessible. This was not unnatural for the horribly dirty lane that led to it from the crowded and filthy road outside the city, might be passed and repassed without its giving the slightest hint of the promise it held.

Queen's Funeral.-To return to the funeral of the Queen. This took place November 21 and 22, I897. Even had the body been preserved entire there would have been a very long interval between the death and the burial, the remains being embalmed after a fashion and kept in ice, while the court astrologers were selecting a propitious day for the interment and while the preparation of the site proceeded.

The foreign representatives were invited to be 
present at this burial and for their reception a row of neat little houses had been especially erected, together with a dining hall, which latter was placed in charge of the keeper of the French hotel in Seoul.

The ceremonies of the interment took place at night and we were expected to do our sleeping between times. It was chilly weather but each little house had its tiny stove, while beds, blankets, chairs and tables, were furnished for our convenience.

Each minister had with him such official guests as he had announced beforehand he would invite. A number of naval officers from one of our ships at Chemulpo accompanied me officially.

We went with the great procession, being carried in sedan chairs borne on the shoulders of four men for each chair. The procession proper was long enough to cover the whole five or six miles of the route to the grave. It consisted of companies of soldiers, some in modern equipment, while others were clad in the ancient coats of mail wearing metal helmets surmounted by gay plumes, and carrying long spears or bows and arrows.

There were great "flower horses" of papier-mâché, to be burned at the tomb, together with similar grotesque figures for frightening off or propitiating evil spirits. There were two biers supported on the shoulders of scores of bearers while great ropes extended from the front and back and were manned by hundreds of men, who like the bearers were dressed in sackcloth. 
The reason for the presence of two biers was in order that any evil-disposed spirit might be confused as to which one to devote his attention to and thus each might escape, for like other primitive people who are troubled with an active belief in evil spirits, the Koreans do not credit theirs with a very great amount of intelligence, judging from the simple schemes they employ to circumvent them.

Much of the day was spent in getting started and in making our slow progress to the cemetery. Soon after our arrival we were served with an elaborate meal, after which we spent the night in attending the numerous ceremonies with the ruler and his court as well as in getting snatches of sleep. It was at this dinner that we received the first news of the German seizure of Kiaochaou and I fancy this had more to do in banishing sleep from our eyes than had the quaint ceremonies themselves. We returned to our homes the following afternoon.

Mourning.-Mourning, it may be inferred, is a serious matter in this erstwhile hermit kingdom. For a parent the family goes into mourning for a period of three years, during which time the sons don sackcloth and a rope girdle, sleep and live in a straw hut erected near their own comfortable dwelling, and indulge in the plainest of food with no luxuries, wine and music, with their accompaniments, being particticularly prohibited. Should the mourner be obliged to venture out after a time, he must go clad in unbleached white raiment wearing a hat of fine woven material of about the size of an umbrella, while for 
greater privacy he wears a shield of sackcloth before his face.

For many years the Catholic priests wore this costume as a disguise while they were being persecuted for being in the country. The dogs would, however, detect the ruse, and thus some of these valiant pioneers were apprehended and brought to grief.

This mourning retirement, compelling as it does the neglect of business, is a grievous burden at times, and causes such a drain on the family resources as to quite impoverish a supposedly well-to-do estate. The very poor are obliged to observe but the symbols of this grief, yet even to them a death and its consequent funeral and mourning is a serious thing for the surviving family to contemplate.

White-the Mourning Hue.-In the case of the demise of a royal personage the whole nation must go into mourning for three years, during which time only white garments may be worn, since that is the colour of mourning. The very shoes are then of white and even the pipe stem must be wrapped in white or bear a bow of that colour. The peculiar shiny black gauze hats are then exchanged for others of unbleached bamboo fibre, or if one is too poor to buy a new hat, white paper is pasted over the black one. Music and dancing are given up and mourning ceremonies take their place, while marriages must be postponed until the strict period of grief has passed.

Life seems very precious to a people who strive so to enforce upon their descendants the observance of their memories, as though reluctant to loose their 


\section{THINGS KOREAN}

hold upon the scenes and instruments of their activity. The duties of filial piety, however, are so deeply inwrought into the very natures of the people that the care of the graves, and the periodical mourning and offering of sacrificial meats are so strictly observed that one of the common causes alleged in some of the trumped-up charges, wherein a neighbour or a petty official desires to trouble a native in order to extort money from him, is that he has neglected or desecrated the grave of his ancestors.

In short it is a land where the dead seem to receive more careful consideration than the living and where they occupy the most pleasing of all sites and surroundings. 


\section{$\mathrm{X}$}

\section{A MISSION TO WASHINGTON}

LANGUAGE, like clothes, does not make a gentleman. In other words a gentleman is such regardless of his nationality, his attire, or the language of his nativity.

In 1888 I escorted a Korean minister, and his suite of twelve, to Washington, and established them there - the first Korean legation to be established out of Asia.

It was in January that this unique party burst upon our capital, clad in delicately tinted silk gowns, and wearing their hats in the house. And such hats! They were made of glossy black horsehair, silk and bamboo, with the crowns, shaped like truncated cones, rising from rims six inches across. Social functions were in full swing and we went to the more important ones.

The Début.-It chanced that we made our début at the house of Secretary Whitney, and in order to render the ordeal less trying we went early. General Sheridan had agreed to go in with us and give us some help in starting. He was on hand when we arrived and piloted us through the introductions and escorted us to the ballroom, where the rest was easy, for the guests promptly came up and presented themselves and the ladies proved especially interesting. 
It seemed that some of them thought it necessary to say something to identify themselves. Several explained the rank of their husbands,-present or late. One elderly lady called especial attention to the several strands of large pearls encircling her somewhat stout neck, and asked me to explain to the minister that these pearls were all genuine. This explanation was somewhat difficult to render since I had first to make it known that there were false pearls to be had in our country.

The best of all, however, was when a beautiful lady with a charming southern accent, followed her presentation with a cordial invitation to come to her state and make them a visit. She told of some of the attractions of which her people were wont to boast, and added that it was further claimed that the women of her state were particularly fair to look upon.

A Clever Sally.-When I had explained this to the minister he replied at once without hesitation, that having seen the lady herself he could well believe that statement. This from an Oriental who was meeting ladies in public for the first time.

When we had first entered the salon and noticed little groups of ladies, the minister remarked in an offhand manner that he supposed these were the "gesang" or dancing girls. His surprise was very great when I assured him they were the wives and daughters of our most distinguished citizens, whereupon he asked if it would be proper for him to look at them.

Considering the tremendous change from quaint 
Korea with its small and dimly lighted apartments where respectable women would never be seen by strangers, to this great brilliantly lighted interior, echoing with unfamiliar music and with the laughter of women mingling freely with the men, it seemed that this courtly old man in his silken robes, proved himself to be a gentle man indeed by his dignified deportment under such unfamiliar surroundings.

Decolleté.-It was to them a great surprise to note the costumes of our ladies. The décollete was especially surprising and one of the younger members asked why, since the lady shivered, she did not hitch up her skirts. Any one who has seen a native hitch up his or her clothes when the slack waist belt was felt to be sagging, will appreciate how irresistibly funny this remark seemed.

The Dance.-I forget whether it was at this function or at a later one that they saw the first dancing. It had been something of a disappointment that these people had not shown greater emotion when viewing for the first time some of our wonderful institutions. Hongkong, rising tier above tier, made such a fine display that our cities were shorn of much of the surprise I suppose awaited them. The little steam cars of Japan secured the wonder that might otherwise have been bestowed upon our great transcontinental trains, but there was no lack of evidence of surprised emotion when these strangers saw their first waltz. Years afterwards when the Korean court had a band of musicians that creditably rendered Western music under the guidance and instruction of a German 
teacher, I have asked foreign ladies not to dance at palace functions because of the manner in which the same was regarded by the natives.

The mention of this apparent stolidity or lack of appreciation brings to mind one incident in connection with which there was no such lack.

The Elevator.-Arriving from our ship we entered the elevator at the Palace Hotel in San Francisco. It was quite a little room with divans along the sides. Some of the Koreans had comfortably seated themselves, while others were standing about seeming to wonder why we were all put into so small a room, when the operator pulled his rope and we began to shoot skyward. With horrified exclamations, as one man they seized me, exclaiming about earthquakes in the greatest alarm. After that, when stopping at hotels, they insisted on having rooms low enough so they might dispense with the use of elevators. It was amusing to see them go clattering up the stairs in their sandals, a sort of foot gear not meant for stair climbing and used in a country where the houses are of one story, without stairs, and where the shoes are left outside the door on entering a house.

Presentation.-There were many amusing incidents connected with the reception of this quaint mission, not the least of which occurred at the reception given by President Cleveland. This was held in a room looking towards the monument. We had entered with Mr. Sevelon Brown of the State Department, and shortly the President came in attended by Secretary Bayard. The absence of any uniform 
entirely misled the Koreans and the minister did not realize that the President was actually before him, but was awaiting the appearance of some one gorgeously attired. When he realized his mistake and was further embarrassed by not being allowed to make the three bows due royalty, with knees and forehead on the floor, he quite forgot his part, and on taking out his credentials to read, he missed the key and could not properly intone the speech. My desire to "laugh in meeting" was simply painful, but the President and Secretary showed no outward signs of amusement and soon had their guests quite at their ease.

It had been no small matter this getting established in Washington. At that time China was trying to enforce an old claim to suzerainty over Korea and she had opposed the sending of this mission, one object of which was to assert the independence of the country.

Obstructions.-The then Chinese minister in Korea was Yuan Shi Kai, the great man of China to-day. He attempted to prevent the departure of the mission but was embarrassed by the fact that a foreigner was connected with it. Then the American Government despatched the naval vessel Omaha to transport the mission to Nagasaki, which further complicated matters for the Chinese. As they were steaming down the bay the Omaha passed between the lines of a Chinese fleet sent to intercept them and for a time they were greatly alarmed by the salutes until they were assured that, instead of being fired upon, Chi- 
nese powder was actually being burned in honour of their departure.

Arrived in Washington we found that the clever Chinese minister there had announced that he would introduce us as vassal envoys. Being told of this announcement and that we would have to settle the matter among ourselves, with the further assurance that as vassal envoys we could not be received, it became my duty to defeat the demands as well as the persuasions of the Chinese minister that we consent to be introduced by him. This was eventually accomplished, though I had to tender my resignation as an alternative with the prospect for the minister of a return to Korea in disgrace and unattended.

Later when the minister returned to his country he bore with him a document in which I took all the responsibility for the course pursued, but the Chinese minister in Seoul insisted so strenuously upon punishment that the returned minister was banished. That is he went out of the city walls to his country place for the space of three days; thus the Chinaman "saved his face" and the Koreans secured the establishment of a foreign legation.

Adopted Father.-Afterwards, for many years, I was associated with this gentle-mannered ex-minister in his own land, and learned to regard him with great respect and to entertain for him a sincere affection, so that in what might be called a half joke, I adopted him as my Korean father. This afforded much amusement to mutual friends in a land where it is common, and a very serious matter, for a man to 
adopt a son, but where the adoption of a father would rank akin to the begetting of one.

However, the old gentleman was pleased and as it was simply a foreign way of looking at things it was accepted. Western ways seem to them so proverbially reversed that I have heard of Asiatics who actually believe that in America the trees are inverted and the leaves grow under ground while the roots wave in the breeze.

It chanced on one occasion to fall to my lot to recommend a prime minister, at a time when the Korean Government was passing through one of its serious crises. Of course the ex-minister was named, and his quiet, firm, conservative ways, served to conduct the government safely through that critical period.

It may be added that another member of that mission was made prime minister by the Japanese after they took over Korea in 1906, while two others have held very high rank with their government. In later years the Korean Legation in Washington was sadly neglected. Indifferent men secured appointment thereto and it became of little repute. But the old minister was, and remained until his recent death, a remarkable man. For one thing, in a land of plural marriages or concubinage, he had but one wife. He never took wine, and his instincts were high. He was intelligent regarding great subjects and matters outside his own land. It was always a pleasure to me to make my occasional visits to him, when we would sit cross-legged on little 
cushions on the warm floor and smoke. He would use his long pipe reaching almost to the middle of the floor where it rested in a polished copper tray, but for me he would always have a cigar, knowing I disliked using a pipe lit by an attendant.

Possibly this account of one of them may serve to show that there are gentle men in Korea and that a man may be a gentleman in any language as well as in any garb, however quaint the latter may be. 


\section{XI}

\section{MISSIONARY COMMENTS}

AfTER a year's residence in Nanking and Shanghai as a medical missionary of the Presbyterian Board, I conceived a great desire to go to the newly opened Korea, and was offered letters by prominent men in Shanghai that it was thought would enable me to so establish myself among the foreign residents then flocking to that land, as to result in building up a rather lucrative practice there. In fact my medical friends urged me to abandon the mission work and go to Korea with the intention of growing up with the country. I submitted the matter to the authorities in New York and was instructed by them by cable, to go to Korea in their interest. It seemed that they had been for some time anxious to locate in Korea but missionaries were not then allowed in that country, hence my proposition came most opportunely. I went immediately and remained for three years under the auspices of the mission, resigning, with their good-will and approval, to enter the Korean diplomatic service.

The venture was a success, for when our minister was asked if I were a missionary he replied that I was physician to the American Legation, which introduction, if a little misleading, made all smooth sailing until such time as Western medical science 
could "make good" and secure a place for itself. I was soon made a member of the staffs of other legations than our own, besides being appointed physician to the palace, the maritime customs, and the hospital organized in my behalf. In this way I was enabled to establish myself and to receive and assist the clerical missionaries who arrived in due time, and to whom is due the marvellous success for which that mission field is so justly noted to-day.

Banner Mission.-Korea now stands at the head of all such countries for the success of the missionary work conducted therein.

The people really have no religion of their own. Confucianism is merely a system of morals without God, and Buddhism has fallen into disrepute. At the same time the natives are by nature devoutly inclined and Christianity naturally appeals to them. Then there is no caste to hinder the propagation of religious truths and the organization of communions, as in India, all of which tends to open wide the way for the work of the missionary.

Some Causes.-It has often seemed to me that the Christian religion may owe some of its popularity in Korea, to the fact that it offers the people an opportunity to even up matters with their official class, for, as in the Orient generally, the masses have from ancient times been sorely oppressed by their officials, and this religion, in making all people equal before the final tribunal, offers among other hopes, this great one of being able one day to stand on a footing of equality before their taskmasters. This 
hypothesis is mentioned in no irreverent spirit, but it covers some deductions made from actual experience and seems to offer a not improbable, if partial, solution.

The Bible.-Then the Bible being an Oriental book, its teachings are easy of comprehension. To mention going outside the city conveys a real meaning to people living within high city walls; and sitting in the city gates to administer judgment, is a most natural occurrence in a land where official edicts are posted in the great gates that pierce those walls, for all passers-by to read and ponder.

The child at home who reads of the watch-tower erected in the vineyard, naturally thinks of an impossible structure of stone and iron, but the Korean at once sees a little platform raised on four poles and covered with thatch, where the farmers sit and keep watch over such crops as melons and similar ready-to-eat and stealable products.

The ships, which sometimes puzzle the Sundayschool scholars at home, who are liable to confuse them with our great vessels of to-day, are to these natives simply the nailless junks so familiar on their own waters, either entirely open or possessing a little cabin; while the miraculous, whether in subduing storms, casting out devils or restoring sight to the blind, is what is to be expected by a people brought up upon a firm belief in supernatural intervention.

The Fifth Commandment.-With an inclination towards religion there is little to give up in accepting ours, excepting some portion of the so-called ances- 
tral worship. This, however, has to be handled with some degree of caution lest its abandonment bring about a worse condition of affairs, for it has its good points as well as some that may be considered objectionable. What nation has so well observed the fifth commandment, unknowingly though it may have been, and by honouring their fathers and mothers, have been long in the land given them, as these Asiatic nations, particularly the Chinese, to whom, as to the Koreans, filial piety is a duty seldom neglected and respect is shown to elders and the aged as a matter of course.

The War.-Prosperous as was the Korean mission work before the Russo-Japanese war, however, that great conflict and its dire results to Korea, vastly stimulated missionary effort and increased its rewards. Since that war the Koreans have seemed to have no one but the missionaries to whom they may turn for sympathy, and incidentally it may be mentioned, that many awkward questions have been put to our people regarding the conduct of our own government in turning a deaf ear to Korea's plea for the kindly offices promised them in our treaty, to be forthcoming when just such a difficulty as this should occur, and in consideration of which promise they consented to the opening of their country to the ingress of Westerners.

So great has been this turning to the missionaries that it has been difficult at times even to examine the numbers of applicants for baptism and reception into the church. 
Pengyang.-The most successful mission station in Korea is that in and about the northern city Pengyang, where a congregation of over two thousand is the rule, even for a prayer-meeting, while schools, hospitals and other branches of missionary effort are taxed to their utmost capacity. Native preachers and helpers have been educated and set to work and some of them have been instrumental in contributing largely to the success of the work.

A Revival._A remarkable revival recently swept over the missions in Korea, starting apparently with a sermon preached by a blind Korean, at Pengyang, on the text " confess your sins one to another."

One result of this revival was a wholesale confession of sins ancient and modern, causing some of the confessors to suffer for crimes almost forgotten, or known only to the one committing them. So contagious was this upheaval that the very missionaries themselves began confessing petty lapses from the strict ideals they had set for themselves, and one actually confessed shortcomings of such a grave nature that he had to leave the country and the work.

The revival movement seems to have extended to the casting out of devils and the miraculous healing of the sick, while the contagion seemed to affect the non-Christians, causing them to repent of their sins and seek admission to the communion.

High Class Missionaries. - The missionary body in Korea is made up of a very superior company of men and women. Both sexes are apt to be college graduates while the men are in addition graduates of 
seminaries or medical schools. Quite a number have shown marked scholarship in the study of the language, in interpretation and translation, and in general literature. Historical and descriptive works of value have been published by them, while at least one extended and well-received romance is the result of one man's leisure, and another was a contributor to some of our best magazines.

Practical Assistance.-The missionaries have assisted the natives to better their condition by the introduction of improved tools and agricultural implements, in the use of which they have instructed them ; only to have them revert to the ancient customs when the stimulus of the foreigner's presence was removed, and jealous natives began to complain of their aping foreign ways and abandoning the good old methods of their forefathers.

The missionaries have instructed the people in sanitation and hygiene and in the proper care of infants, thus saving the lives of many children. In addition to medical aid actually rendered, the natives have been taught the use of quinine, which is now on sale, together with some simple household remedies, in all parts of the country. Schools have been opened for the training of nurses, which will be a great boon to the sick and will cause a saving of money to the people and a diminution of the gains of the astrologers and spirit doctors. Manual training-schools and printing-presses are in full working order and the people are being taught by the missionaries better to fit themselves for the more bitter contest for a 


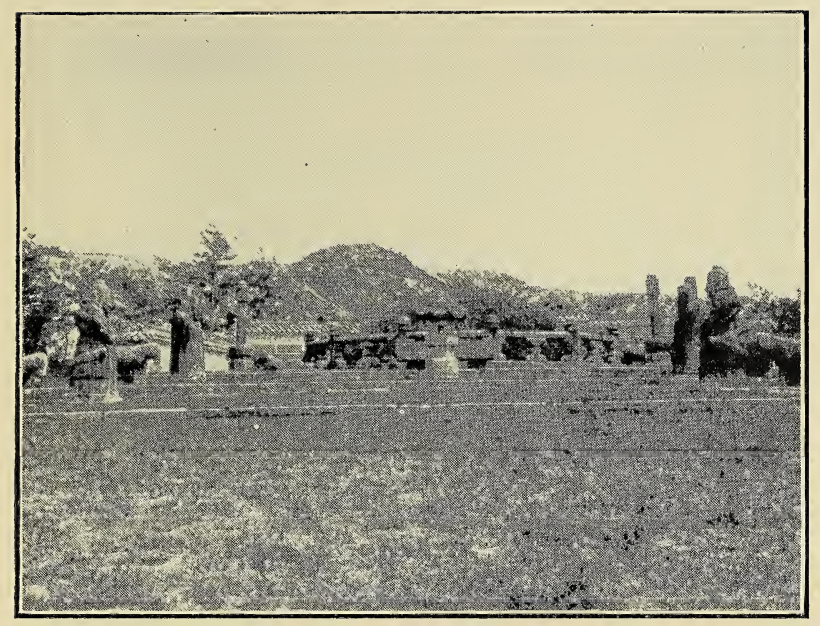

A ROYAL TOMB

See page 153

The Grave and Its Surrounding Figures

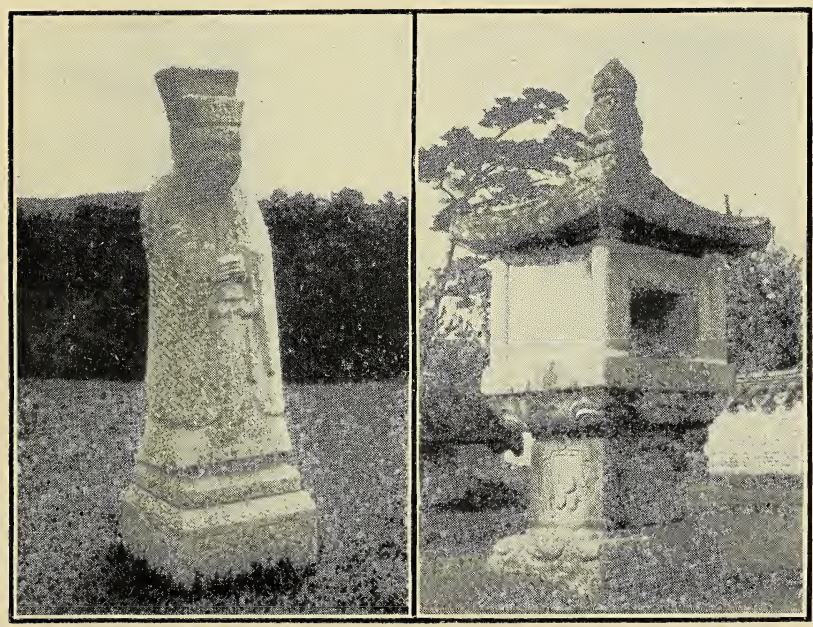

See page 153

ONE OF THE PRIESTLY FIGURES A STONE LANTERN 

living, brought on by the new conditions which prevail in the country.

With their land absorbed by a hated rival, a feeling of desperation has seemed to settle down upon the Koreans. Some take up arms against the intruders and thus virtually commit suicide; others sit stolidly and deplore the passage of ancient abuses, for however much they may have deplored them at the time they were their own and to be tolerated; others join the newcomers and make profit for themselves, while many others are turning to Christianity as the solace for their woes and the only avenue that offers hope to those accepting the invitation to walk therein.

Exceptions.-While as a rule our missionaries combine common sense with superior mental qualities, among so many there must of course be some exceptions. One man lost his patience while a guest at a Buddhist temple and began smashing the little plaster idols with his cane, so that his fellows were excluded from entertainment at that place for some time. This was a somewhat noted case at the time since the British representative urged drastic measures in punishment, on the ground that his government would never allow any interference with the native worship in India and that we owed it to ourselves to take the same course in this newly opened country. I did not have to do more than consult with him and with his associates, who deeply regretted his lapse, and get from them jointly a promise that nothing of the kind should be allowed to occur 
again. However, the man, not now in Korea, did break out again and wrote a letter to the Emperor calling upon him to repent of his sins and asking to be allowed to preach repentance to him. As the letter was written by an ignorant native scribe who used terms that amounted to an unintentional insult, the matter was referred to me and again I was obliged to get a joint promise of good behaviour.

We had one representative of a strange new sect, who seemed to devote his time to an attempt to proselyte the converts of the other missions, for his chief teaching seemed to be against Sabbath observance; an ordinance which was difficult enough to enforce as it was, in a land where the people lived from hand to mouth and no wage meant no food for that day. The worst of it was that this man was a highly cultured graduate of a great English college and was altogether good and admirable but for his queer crotchet.

Denominations.-While the Catholic Mission of Paris is the oldest and strongest body of mission workers in that country, with the largest communion, the Presbyterians are the strongest of the Protestant missions, with the Methodists following close after them. The Episcopalians are represented by the Church of England and with a bishop, and male and female orders. They also maintain hospitals and schools and provide regular Sunday services for the foreigners. The Baptists opened up work in Korea, but probably the native aversion to bathing may have extended to the rite of immersion, at any rate 
they soon left the country and went to Japan, the land of the bath.

Rich Missionaries.-Besides being well educated, some of our missionaries in Korea are well provided with this world's goods, so that they assist in the support of other missionaries and are therefore more than self-supporting, so that it cannot be said in their cases, that they are there for the sake of a position or for the ease of the life or the charm of the surroundings.

Sacrifice.-Too much emphasis seems at times to be placed upon the idea of the sacrifice the missionary is making in taking up this life. It is indeed a sacrifice to leave one's family and friends, but that has to be done even when remaining in the home land and moving about in following opportunity's lead. Officials and business men are obliged to do the same when they go abroad, but the idea of the tremendous sacrifice does not deter them.

The real sacrifice comes when the family must be broken up by sending the children off to a distant school, but this is a sacrifice not at all confined to the missionary class.

Comfortable Surroundings.-Life in these Oriental countries has many compensations. Comfortable quarters are provided if possible and a physician is usually within reach, for he is one of the most useful members of the missionary community. In a land where servants may be had for three dollars of our money per month, and feed themselves, it would be folly for the missionary or his wife to devote their 
valuable time to work that a servant could do better at so little cost. This tends to make the life more agreeable, and actually seems to offer an attraction when mentioned at home in the presence of housekeepers struggling with the ever-present problem of domestic assistance.

Lack of Sympathy.-An elderly missionary lady once remarked to me that she thought the hardest thing she had to contend with was the lack of sympathy. She had been a highly respected member of a large and cultured circle in her home city, where she was surrounded by the usual luxuries of the well-to-do, and in coming to the Far East she said she found she belonged to a despised class.

That was putting the case in rather strong terms perhaps, but still it is a fact that the general foreign community does not waste much sympathy upon the missionaries as a body.

Having belonged to both classes I have given the matter some thought and it seems to me the blame for this state of things is not all on one side.

The Foreign Resident.-The foreign community in one of the port cities of the Far East is made up of the same materials as are our home towns. The successful men of business are of the same class of men as those who succeed at home. If they are men of family they usually claim some sort of church connection, and they are certainly most charitably inclined when a meritorious object is presented. Often, however, they may have come at an early, unformed age, to this region where the conven- 
tions of their former homes are absent; where the native idea of morals is usually conspicuous for its absence, and where it is more than easy to follow the example of their elder associates and contract habits or connections which they may manfully strive to correct when time has allowed them to get their bearings and their better judgment asserts itself.

Merit Counts.-Let a gentlemanly missionary come to this community, possessed of some talent that makes him a desirable acquisition, whether it be a good voice for singing, the ability to make music upon'some instrument, or skill in some good vigorous game of athletics; let him even be a good storyteller or be simply endowed with good sense and good nature, backed by learning, and he will be taken up gladly and find real human sympathy, even if this may not extend to his work for the natives in just the comprehensive manner he might wish.

Further, such a man may find that an important side issue of his work will likely be the giving of sympathy to these fellow countrymen, who have their own trials and discouragements in the new land, and in so doing he may gradually win them to the ideals left behind with the distant home.

A missionary of this description, and I have known such, who has something to give to the community and who is willing to give it, will not be ostracized or lack for sympathy and the companionship of his kind. He will on the contrary be welcomed and be made a part of that little band, and it will be for him 
to say just how much or how many of the attentions open to him he shall or may accept.

There are missionary names of good men, some of whom are now long dead, which are revered in the communities of which they were members, and to whom more than one prosperous and successful business man of substance and position in the community, looks with deep regard as to one who had given him real help in climbing out of the rut of personal gain and creature comfort, or what may have passed for pleasure.

Mixed Marriages.-It should be borne in mind that while the missionary usually comes with his wife or has a sweetheart at home who is coming to him, quite willing to share his pittance, the young man whom business suddenly calls to these foreign shores, comes alone, with no place in which to spend his leisure aside from the little club, and with no chance of having money enough in the visible future to support an expensive foreign wife, while a coy and fascinating native maid will gladly be his home companion for as long or short a time as he may wish. Moreover, as his friends have in many cases made themselves homes of this character, it is easy for him to do the same.

Austerity Ostracizes.-Now if to one of these little settlements there comes a man who conceals whatever knowledge or accomplishments he may have under a general frown of disapproval; who brings nothing that will add to the pleasure of the community, or who carefully guards any such ac- 
complishment from contamination as he clutches his skirts about him to avoid contact with the, to him, depraved members of the community; who preaches, and writes home, that he is unable to accomplish any good because of the awful example of the drinking men of his own nationality near him, he will be shunned and made an object of ridicule. When this begins to wear upon his nerves he is apt to console himself with the thought, and to state publicly, that he is thus spurned because he is such an example to the others and such a reproach to them for the lives they lead.

Poor misguided misfit, what he needs is a better digestion; a more wholesome view of life in general; more ability to make himself agreeable and consequently useful; more charity for his brother so he may give to him that sympathy he so needs, and in the giving gain for himself not only sympathy but an appreciation that may well lead the other to strive to mend the broken places in his life, and thus remove the very obstacles of which the missionary is inclined to complain.

Of course in every community there will be depraved characters; these outposts are no exception to the rule except that there human nature may assert itself more openly, and the human may be more apt to revert to the original.

New Material.-It has seemed to me that much of the disfavour sometimes expressed by the foreign residents of Asiatic ports towards the missionary class, may be due to the unwise conduct of the new 
missionary, who is usually fresh from some small community where he has been the subject of some adulation because of the life he has chosen for himself. This may have given him an undue estimate of his own importance. He may be too young or inexperienced to feel that sense of charity for those who may not agree with him, that would seem to be essential in one bent on such a mission as that entrusted to him, all of which may well give him the appearance of being a bigot, a fanatic, or a fool.

If the young missionary could only suppress himself until he gets his halo adjusted so it will not topple over and obscure his vision, he would obtain a better view of things and might save himself and his associates some unpleasantness.

Fortunately this newness wears off in time and a feeling of charity and brotherly love sometimes takes the place of what may have seemed to be a somewhat marked belligerency and self-assertiveness. There are names of venerable missionaries, so numerous as to need no particular mention, which are household words in the communities in question; the bearers, whether living or dead, are certainly held in such general esteem as to seem well to merit the decoration of a halo of respect and affection. I have often wondered if they, when newly arrived on the scenes of their life's labours, were as raw, inexperienced, and apt to offend as are some of the new ones I have seen. Perhaps they were, and possibly the constant arrival of the raw material will continue to preserve the old attitude of antagonism between 
the general body of missionaries and the secular representatives of Western civilization.

Above the Law.-The missionary occupies a unique position in these so-called heathen lands, where he goes about as he pleases and often takes a house and settles down with his family in some far distant interior town, whereas his commercial brother usually restricts his residence to a treaty port or enters the interior as the result of some special business regulation. The uniqueness of the missionary's position consists in the fact that he is above the law of the land since his treaty grants him extraterritorial, or exterritorial, rights, which means that he is not under the jurisdiction of the courts of the land and can only be proceeded against before his own consular court. This places great power in his hands, and an unwise or over-sympathetic missionary is pretty sure to be led into a greater or less number of cases wherein a native desires to profit by his Christian connection and obtain foreign protection. This protection may result in a serious wrong to some other native concerned in the matter but who has not such protection, and even if the case be a meritorious one it is apt to excite ill feeling on the part of the non-Christian natives. Moreover, the hope of this sort of assistance sometimes induces people to flock to the church. It results in many abuses, and some poorly explained cases of destruction of property in China are supposedly due to animosity growing out of certain impositions upon the missionaries, wherein their names and influence 
have been used, it may be without their full knowledge, to promote the interests of native Christians, real or nominal.

We had one extreme case of this kind in Korea wherein Catholic and Protestant communities were pitted one against the other, necessitating a long investigation on the part of the French and American Legations respectively, and an extended reference to the central government. Fortunately no blame was found to be attached to our people in this matter.

Exterritorial Rights.-It would seem to be unwise to bestow such power as this upon the whole mass of missionaries. A few carefully selected men might use it without abuse and for the good of all, but to clothe men indiscriminately with these exterritorial powers and send them into the interior away from their own authorities, and where they would be subject to no law, seems to be a mistake, since some of the men will surely prove to be weak either in temper, judgment, or sympathy. When trouble does come of course the native is the one ultimately to suffer. Every time a case of that kind occurred in Korea, such as the violation of the domicile of an American by the overzealous officials of some interior town, it was a foregone conclusion that the native would have to pay for the " outrage" by being obliged to grant new and larger liberties of residence or ownership of property, in violation of strict treaty provisions. Not that any such incident was courted for such purpose, but it was the duty of the representative to get the best possible settlement for his 
nationals, consistent with justice and a liberal interpretation of the treaty, and the native had usually blundered so in the beginning as to make it possible to get very considerable advantages in consideration of settlement.

The great privileges of residence and property ownership now enjoyed by missionaries in China, came to them, by virtue of "the most favoured nation clause" of the treaties, as the result of demands enforced upon the Chinese government by France-as the protector of the Catholic church. In Korea we Americans took the initiative and emancipated the French who were living in disguise when I went to the country, and owned no property in their own names. Now they own property in many parts of the country and their cathedral building in Seoul dominates the whole city.

Japan secured the abrogation of these, to her, obnoxious exterritorial rights, and she will now keep such a close supervision over affairs in Korea that the enjoyment of this privilege granted by our treaty with that country, will hereafter be of little moment. English rule prevails in India, and China and Turkey will be the chief remaining countries where our people will exercise these rights.

New Plans Possible.-I know nothing personally of Turkey, but it begins to look as though China might soon commence to assert herself and demand, as a counter-claim to the insistence of our people in regard to non-immigration, that we either recall our people from her interior or place them under the 
jurisdiction of her officials. When that time comes, as it will sooner or later, it will be well for the boards of missions to consider the restriction of missionary residence to the treaty ports where they may have their homes, their hospitals and schools, with seminaries for the education of a native ministry that shall do the actual work among the people of the interior, under the superintendence of travelling missionaries, who should be men who have lived long enough in the land to know the language and something of the laws and customs of the people. Moreover, these men should be men of wisdom and discretion, which would necessitate the sending of the younger members with their elders for a course of training.

The devoted wives and helpless children would then be safe in time of uprising, and the itinerant missionary himself, being freed from this incumbrance, might more often escape and martyrdom would be less frequent. It does not seem, moreover, that martyrdom such as this sows the seed of the church as persecution is supposed to do, for reports are to the effect that such destruction of lives and property usually causes a marked setback to the mission work in the locality where such unfortunate events take place.

Litigation.-It seems to be a mistake for the missionary to be too much given to litigation, that is of promptly taking his own troubles and those of his native followers, to his consular or diplomatic representative. 
This tendency seems to have been somewhat checked by the great "Boxer" movement in China and I noticed in recent years in Korea, an evident desire on the part of our own people to confine their efforts more to the spiritual uplifting of the natives, and an inclination to discourage the bringing of the property difficulties of their followers to the consulate.

Formerly this was not the case, and one missionary remarked somewhat indignantly, when it was shown that a gunboat could not be summoned in the support of what was really a petty matter, "Well, what is our navy for if not for the protection of us missionaries."

Self-Help.-There were always some missionaries who were able to settle their own troubles. One case in mind is illustrative. It was that of a most estimable lady of Seoul, whose native cook had been arrested on Saturday night upon some foolish or trumped-up charge. His mistress had no intention of shielding him from the due consequences of any misdeed, but she had many to cook for and she wanted him tried, and either punished and freed, let out on bail, or acquitted. Instead of coming to me that Sunday morning she went direct to the governor, and when told that she could not see him, she sat down on the veranda and announced her intention of waiting until she did see him. Such a remarkable proceeding was entirely without precedent in native law or custom and it soon brought the official to the door. This official was rather clever and suggested that as it was 
Sunday it was not right to force him to work on that day. But the lady asked him if he intended to fast because it was Sunday, or if he wished to compel her and her school to fast. This was too much for the representative of the law and, to cut a long story short, the cook was at once released unconditionally and allowed to go home with his mistress.

There were some missionaries for whom it was always a pleasure to work. They only came for assistance when they had meritorious cases well supported by the necessary evidence. Others were inclined to rush to the legation or consulate on the slightest pretext and their calls were dreaded, since one never wished to appear unsympathetic or disobliging. Yet it was most distressing to be continually obliged to intrude some petty missionary case of emergency into delicate negotiations of a more or less serious nature, for the native would naturally be inclined to shift everything over to the minor matter, and thus influence for good on large matters would be likely to be dissipated, as was often the case.

Gratitude.-My missionary neighbours were almost invariably responsive and grateful, and through their voluntary representations numbers of unsolicited and unexpected letters of commendation were sent by the boards to the Department of State, regarding its representative and certain timely assistance rendered. Copies of these reached $m e$ in due time in an official manner.

When my time came for leaving the country with 
which I had had much to do during twenty-one years, these good people voluntarily took it upon themselves to endeavour to have me retained, which made the departure the more agreeable, since as I had been one of them for three years, it was pleasing to have the assurance of those who knew me best, that in the eighteen subsequent years of official life in that land, I sufficiently met their approval to induce them to strive to prevent my departure. 


\section{XII}

\section{MEDICAL NOTES}

As has been elsewhere explained, we arrived in Seoul a few months before the outbreak of a bloody emeute wherein Western medical and surgical methods were favourably tested. The medical successes in this instance prepared the way for the opening up of missionary work proper, while it incidentally opened the way to the medical man for quite an unexpected career. The recovery of the wounded prince, in addition to furnishing me with a hospital, led to my appointment as medical officer to the royal court where my advice was naturally sought on matters other than medical, all of which resulted after a few years, in my abandonment of the medical work for a career which led through the Korean service abroad, into our own consular and diplomatic service; where I held all the positions from deputy consul to consul general in the one, and from secretary of legation to the first ministerial post in the diplomatic service.

A Hospital.-That early success with the prominent native prince caused the natives generally to come for treatment for all sorts of ills, real and imagined. As a consequence I asked for, and obtained the use of a building in which to see and treat these people. This, the first modern hospital for the 
Koreans, was named by the ruler, Chai Chung Won, or house of civilized virtue. It had been the home of one of the officials who was assassinated in the emeute and some of the rooms were blood stained when we took it over. The house was put in good repair and the afflicted came in hundreds, over ten thousand being treated the first year. In time a better site was granted with a more commodious building, and long after my connection with the institution had ended and the hospital had lost its government connection and become purely a missionary enterprise, as was found to be much the best plan, a fine brick building with modern equipment, on an excellent site, was provided for the very capable physician in charge, through the munificence of an American gentleman, Mr. Severance, for whom the hospital is named.

Some of the incidents that occurred in connection with those early days of medical work are amusing in retrospect, though the serious ones seemed grave enough at the time.

Chinese Post-Mortem.-A year's residence in Nanking and Shanghai preceded our arrival in Korea. In Nanking a soldier from a distant province was placed at our door to die in order that we should be obliged to defray his funeral expenses. We took him in and made him comfortable though it was too late to stay the ravages of pneumonia. When he died the magistrate was duly notified of the circumstances and to our horror he proceeded to hold a sort of inquest. A blue cloth canopy was set up in our 
compound under which the official sat in state and directed the proceedings of his scribes and experts. The latter consisted of a party of so-called doctors who forced a silver tube down the throat of the corpse and tried to pour water into the stomach. The water of course would not go down, whereupon the examiners announced that the man had been killed by being given cold water to drink. This was a safe verdict, for the natives knew of our strange fondness for the deadly cold water. Long experience has shown them the danger that lurks in the use of unboiled water, hence they take their drink hot, usually in the form of weak tea, which they find to be quite refreshing. It was natural for them, therefore, to show their own wisdom by accusing me of having given the man this deadly cold water.

It began to look decidedly disagreeable for us, off in that interior city with but three foreign families in a population of hundreds of thousands of superstitious natives. Further, I was annoyed at such return for my well-meant attentions to a suffering outcast, and, with the assistance of a venerable missionary, I stepped boldly up to the bench of justice and demanded the immediate payment of forty-five dollars for my professional services.

This was too much for the equanimity of the magistrate who exclaimed, "What, you kill a man and then ask pay for it?"

He was so upset at the audacity, and at the prospect of a claim upon him where he may have thought he would have the opportunity to squeeze, that he 
packed up his paraphernalia and left, to our infinite relief, thus closing the incident once and for all.

Strychnine Poisoning.-It is not well to expect too much intelligence on the part of an Oriental patient in the matter of adhering to instructions relative to dosage in taking foreign medicine. I once gave a man a bottle of medicine containing nux vomica, with instructions to take a marked dose three times daily. Desiring to get well quickly and reasoning that if one dose was good twenty would be better, he took the whole at one time. He had a case of strychnine poisoning from which he was rescued with difficulty.

I had another case which I feared might be strychnine poisoning. I had killed an ugly cur dog with strychnine and the gate man had buried him in the garden, under my instructions. In the night this wretched man dug up the dog and his family cooked and ate him, but they suffered no ill effects.

Opium Poisoning.-Poisoning by opium was quite common in Nanking in I883. Having cured one such case by the hypodermic use of atropine, my life was made miserable by constant calls to other such cases. These calls invariably came at night, one after the other, so that sleep was quite out of the question until I made a firm rule that no calls would be answered between ten in the evening and six in the morning. It was moreover a most thankless work. The would-be suicide had usually adopted such course in vengeance so that his or her spirit might return and torment an enemy,-usually the 
husband or wife. The patient on recovery would berate the doctor for causing the loss of so much valuable opium, while the gratitude of the other party was a negligible factor.

These were anxious occasions, passed amid the most squalid surroundings, and it was a pleasure to reach Korea where the curse of opium had not yet spread.

Treating a Queen.-In my capacity of court physician I attended the royal family in person, but at that time I could not see the queen, who in after years saw and conversed with me openly. When she was ill in those days, therefore, a eunuch would pass her hand through a screen, carefully wrapped, with but an inch of the wrist showing over the pulse. The royal tongue would then be thrust through a hole in the screen for my inspection, for as in China, the physician is supposed to make up his diagnosis from feeling the pulse in both wrists and examining the tongue.

One day in order to allay distressing insomnia I sent my royal patient an opiate. At noon the next day as I was busy with a hospital operation, there was a great uproar outside and all the common people hurried out of sight as a great official, dressed in his court robes, came strutting into the operating room, stopping the work in hand. $\mathrm{He}$ at once announced that the queen had taken my medicine and gone to sleep and had not yet awakened. He looked so fierce and uncompromising that my very knees trembled, as I thought of an opium idiosyncrasy and 
my utter inability to do anything for a patient whom I could not see and to whom it would be impossible to administer a hypodermic injection, since no steel instrument might be used on her sacred person, which was to be contaminated by the touch of no baser metal than gold.

I asked when she had taken the medicine and was told she had taken it at five o'clock. This was awful as it was now noon of the next day. I thought of my wife and child alone in this great city nearly two miles from where I was, but before yielding entirely to the collapse which I felt coming on, I chanced to ask "Five o'clock last evening ?" and the officer replied, "No, five this morning."

What a relief! I felt angry at the fright he had given me and told him in very brusque tones to go away and let her sleep as she was doing just as I wished she should. I hurried him out of my way as unceremoniously as I could, speaking through an interpreter. He and I remained good friends after that until he was killed and dragged through the streets by a mob.

It was the rule in the palace, to stay up all night and attend to the business of the government, retiring towards dawn. I did not realize the extent of this custom at that time, however. Later I was asked for a supply of that excellent medicine to be kept on hand in the palace, but unfortunately I had given her the last dose, or so it was reported.

Trials of a Court Doctor.-The position of court physician in those early days was no sinecure. There 
was always the alarming possibility that some serious complaint might overtake one of the royal family, in which case a fatal termination would be facilitated by the total lack of proper nursing, the envy of the native medical force and the inability of the foreign physician to enforce his commands. Such a termination would be fatal to all future success while its probable effect upon the minds of the people, inflamed by the malice of the native doctors displaced by the foreigner, was too awful to contemplate.

Aside from these possibilities, however, the actualities were sufficiently trying in themselves. Lacking amusement, the foreign doctor was as much of a novelty to the court as would be a new toy to children. When no actual complaint was at hand to serve as an excuse for summoning the queer new officer of the court, one would easily be imagined, the feeble young prince being a fertile source of these excuses. The difficulty experienced from this flattering interest in the foreign doctor lay in the custom of turning night into day in the palace, where the court slept while I was at work in my hospital. Then in the tedium of their waking hours at night they would think of me which was equivalent to a summons, for the slightest whim of such despotic rulers is promptly carried out by their servile courtiers.

Usually these calls would reach me at midnight or later and as the messenger would be accompanied by an escort and a sedan chair, the uproar would effectually arouse my whole household. Further, I would be obliged to robe myself in full evening 
dress, since that was taken as our substitute for the court uniform without which native officials could not go before their ruler.

Imagine getting up at one o'clock in the morning, dressing in conventional evening dress and riding miles across the city in zero weather to see a prince who may have fallen asleep in the meantime and whose sacred slumbers might not be disturbed, even to relieve an ache from which he may have imagined he suffered. A long wait would ensue in an anteroom where I would be lavishly entertained by the waiting courtiers who would persist in opening boxes of cigars, bottles of champagne, jars of sweets, and tins of cake, in spite of my protestations that I did not want them. I soon learned that I was a great boon to these tired officials who made my presence the excuse for ordering and consuming all these attributes of civilization, which were so highly appreciated that all remaining cigars, sweets and cakes would be carefully stowed away in their ample sleeves for consumption at their homes, so that on my next visit an entirely new supply would be requisitioned and promptly forthcoming from the apparently ample storehouses. I must have won a reputation in those days for possessing an appetite of colossal requirements. Later, in order to keep themselves in countenance, tea and coffee were added to these collations.

All this was done in the kindest spirit imaginable.

I was even offered native office and revenues, but as the acceptance involved the adoption of native 
dress and a certain conformity to native customs, the honours were declined, though honourary decorations were conferred and accepted from time to time until I was given the highest of such honours possible to be conferred on any but a member of one of the ruling families of the earth.

In view of these nightly calls and the difficulties that seemed to lie in wait for the medical officer of such a court, it is not surprising that it was a relief to abandon this medical work at palace and hospital and enter upon a new career by embarking with an embassy for Washington. During all the years I spent in Korea after my return from that mission, the squeaking of a Korean gate at night served to instantly arouse me and bring on an uncomfortable sensation, as though I were about to be obliged to don evening dress and dance attendance upon a patient who either needed no care, or who might chance on that particular occasion to need attention beyond my power to bestow.

Ginseng.-The main reliance of the Korean pharmacopœia is upon the root known as ginseng. This is the panacea for all native ills where a " heating" medicine is required. The country is noted for the excellence of its ginseng which was one of the royal perquisites prior to the recent Japanese occupation, the sale of the crop usually bringing to the royal purse over a half million dollars in our money each year.

This plant resembles somewhat our May-apple or mandrake, and is cultivated under mat sheds 
for its root which requires seven years to mature. Wild roots are prized above the cultivated ones; genuine wild roots are said to have sold for their actual weight in gold.

Instead of being the inert drug we find it with us, Korean ginseng certainly merits its reputed "heating" qualities. I have seen foreigners and natives with quite an eruption produced by its use. With the Chinese the great merit of the root seems to be for use as an aphrodisiac.

When treating the prince, I was greatly concerned on one occasion by noticing that his wounds had taken on an inflamed appearance with a rise of temperature, for which I could in no way account. At last, after much questioning, I learned that his family, hoping to hasten his recovery, had been surreptitiously administering ginseng to him, whereupon I announced that unless I was to be obeyed implicitly I would leave the case entirely, which made such an impression on them that I had my way thereafter. The bad symptoms soon disappeared leaving me with more respect for ginseng than I had before entertained.

A Quaint Interpretation.-Interpreters were scarce in Korea at that time and I had one of the few to assist me in this case and later in the hospital. He would indicate a decrease in temperature by the pleasing statement that the fever was "increasing to less."

Dog Soup.-One of the strange customs discovered in attending this case was the use of soup 
made from the heads of dogs, as a strengthening medicine or food. This may have been harmless enough but it was repulsive so I took a roundabout way to stop its use. I announced one morning that my patient had a unique manner of getting even with his enemies, since he ate them. Being asked for an explanation I said that I had seen the dogs devouring the dead Japanese lying in the streets and as he ate the dogs, he thus fed on his enemies. After that beef was used for soup; and to our intense relief, the bodies of those Japanese killed in the recent emeute were removed from the streets and buried.

A Dog Poultice.-Among the wounded at the Chinese camp, I found a colonel who had been shot through the groin; the bullet had passed through a natural opening in the pelvic bone without splintering the latter, and when I saw the officer he had the skin of a freshly killed dog wrapped around the wound as a poultice. It seemed to have served well enough, being fresh and warm. As an illustration of the excellence of the Chinese as surgical patients, it may be mentioned that this man was well enough to ride his horse within ninety days after being wounded.

Terra Firma.-Medicines were very scarce and costly in Korea at that time. Quinine was seven Mexican dollars an ounce in Shanghai and iodoform was so expensive that I only had one ounce of it. Being at my wits' ends for drugs for all the wounded and sick people, I remembered having read in an old 
London Lancet of about 1858 , how a British surgeon in Africa, similarly situated, had used clay successfully as a surgical dressing. My household was therefore put to baking clay on the hot kang floors, and this was used to good advantage, as it absorbed the pus and was easily cleaned off for a fresh application. This preparation was much used in the hospital until something better could be had. It was labelled "terra firma" in order that the interpreter might not understand that it was simply Korean dirt that was working such cures.

I understand that the much used American remedy which is quite popular under the name of antiphlogistine, is simply this same old " terra firma" with some drugs added.

Chinese Wounds.-Some of the Chinese soldiers had horrible wounds made by the ancient sawtoothed bayonets carried by the Japanese troops at that time. They were excellent patients, however, even recovering from stabs in the abdomen.

One man had a bayonet thrust through his neck, laying bare the important blood vessels and just missing the vertebra; when the bayonet was withdrawn it took that side of the neck away. The man recovered, however, and was for years afterwards the gate man at the Chinese Legation in Seoul, where he never failed to give me a cordial, if stiff-necked, greeting when in later years I passed his gate lodge as a colleague of his master.

One man died of tetanus because I was not allowed to amputate his badly mangled forearm. 
The Chinese general would not hear to the operation on the grounds that a one-armed soldier would be useless, and a man had better die than suffer such a crippling. He had tetanus as predicted and died from it as it was said he would; the others recovered. As Ambrose Paré, the famous barber surgeon and father of modern surgery, would say in his quaint manner, "I dressed them and God cured them," for of medicine I had almost none before I got through with them.

Rice Diet.-This success must be ascribed largely to the fact that the Chinese are such good surgical patients, which in turn is due in all probability to their non-stimulating rice diet.

Some of our high medical authorities, noticing such good results among the wounded Japanese in the recent war with Russia, have attributed these results to the diet of rice, and have even advocated a ration of that character for our own troops. They probably have never tried sustaining themselves on rice, and may therefore not have proved the truth of the maxim that "rice will not stick to the white man's ribs."

Being brought up on rice from infancy and from a parentage nourished in the same manner, these people thrive upon it, while we cannot hold and assimilate enough rice to sustain us.

I remember that after being up all night with the wounded soldiers at the Chinese camp, following a day of such strenuous work that there was little time or opportunity to eat, I was invited to breakfast with 
General Yuan Shi Kai, and my hunger was so great that it seemed I could eat anything.

When I saw simply three bowls of rice apiece on the table, great was my disappointment, for I felt quite sure I could eat the whole six and then not be content. We began and before I had finished one bowl of the dry, tasteless stuff, with no sugar, butter, milk or other dressing to go with it, I seemed to be filled right up to my throat and could eat no more, whereupon my host took my two remaining bowls and emptied them in addition to the three he had already eaten.

Any one who has travelled in Asia in warm weather and has noted the tremendously distended abdomens of the naked children, will be able to understand that something is necessary in the matter of physical education before we are able to contain enough rice to satisfy hunger. Our small stomachs, accustomed to a concentrated food, simply will not hold enough of this bulky material, and much as I like a rice and curry, I could not put away enough rice that morning to satisfy the pangs of hunger. Our whole army would desert en masse if our men were put upon any such uncustomary and impossible diet.

Teeth.-A rice diet seems favourable to the growth of teeth. The Koreans seem almost invariably to have fine pearly white teeth. They brush them carefully in the mornings, using salt as a cleanser and rubbing it on with the fingers instead of a brush. Coming out of their foul little sleepingrooms with something worse than a "pale brown 
taste" in the morning, the salt is most refreshing to them.

However, they do have decayed teeth as I soon found, somewhat to my regret. I had tried to learn to pull teeth while at medical school, but about the only advice I could get was to select the proper forceps, get a good deep hold, give a twist, and " pull for dear life."

One day a man came in complaining of a severe toothache and to get rid of him I suggested pulling the tooth, since I had found that any such suggestion caused the patient to leave at once. To my surprise this man consented promptly. Carrying out my instructions to the best of my ability, I drew two teeth at one time and was most depressed by the occurrence. Later I saw the man returning before I could finish up my clinic and it seemed I was in for a severe tongue-lashing over taking out his good tooth with the bad one. That was not the case, however; he was bringing his wife for me to extract some teeth for her since he said no Korean was ever known to take out two teeth at one time and with so little pain. Thereafter I had to pull teeth so much that I grew to rather like it.

Cautery and Acupuncture.-The Korean system of medicine is essentially that of China, from which country it was borrowed.

The actual cautery is so frequently used that I have never seen a Korean stripped who did not have the round scars left from the application of hot cash for the cure of some pain. 
Acupuncture is used just as often, and dirty needles are sometimes the means of inducing a more serious disease than that for the cure of which they were used.

I once knew of a very sad case resulting from the use of the chim or needle. It was in the family of an old official to whom I was greatly attached. His only son was the last male of seven generations; he was a handsome, strong young man of about twentyone years. One day he complained of a headache at the back of his head and a friend who was with him proposed giving him a needle; for all educated Koreans seem to think they can practice medicine, in a land where the native doctor is not highly esteemed.

The boy's mother was behind the screen and urged him to take the needle and get relief from his pain. $\mathrm{He}$ consented and his friend boldly plunged the needle into the back of the sufferer's neck, accidentally piercing the medulla so that the young man fell down frothing at the mouth and died. His mother died of a broken heart within a few hours, and my poor old friend was bereft of his son and his only wife; for he was one of the few natives of my acquaintance who had taken but one wife.

Sorcerers.-Koreans believe that some diseases, such as smallpox, are caused by evil spirits, and the exorcising of these demons is a regular business, followed by blind men and a class of women known as mootang.

A great offering of food and cash is made and 
these people, one or more performers, assemble and go through their incantations, consisting of weird dancing and chanting, accompanied by the pounding of cymbals and drums. Sometimes these incantations are performed at the bedside of the poor patient, while at other times the ceremony is gone through at the little temple of the mootang in the near-by hills-a sort of absent treatment.

Frequently when I have been out on professional duties at night and have heard, off the quiet streets, this beating of tom-toms in a distant house, knowing the case to be one not affected by drugs, I have rejoiced in this belief in spirits which prevented the natives from calling on me for aid, and I have wished my fellow practitioner well in his or her incantations.

Smallpox.-In a land where inoculation was regularly performed, vaccination made rapid strides, and I congratulate myself upon the good done in the introduction of vaccination and quinine-for Korea is a land terribly afflicted with mosquitoes and malaria.

Inoculation with smallpox virus was practiced on the theory that since a child must have smallpox sooner or later, it was better for him to have it early, before time and trouble had been wasted on his rearing.

So common is the disease that few Koreans seem to have entirely missed some pitting, while many faces are horribly scarred by the marks of the disease.

An Artist's Death.-In the early spring of 1886 , an artist from San Francisco came to Seoul on a 
professional quest. I chanced to meet him one day when on a vaccinating tour among the few foreigners then residing there. $\mathrm{He}$ declined to allow me to vaccinate him and delivered quite a lecture to me upon what he considered this barbarous custom.

He took part of a Korean house and did not know that in the room next to him, separated by a paper partition, lay a child suffering with smallpox. A few days after he had lectured me I was called to his bedside and found him down with the disease, which assumed its worst form and at his advanced age left him little chance of life. He died a martyr to his theories.

I mention this since a recent number of a San Francisco journal contained quite an account of this amiable man and his sad end.

Doctors' Fees.-The Koreans seem to go on the principle of no cure no pay. Payment moreover seems seldom to be in money. I have been given hundreds of eggs, quantities of meat, live pigs, chickens, pheasant, and all manner of eatables, by grateful patients.

In order to prevent curiosity seekers from taking up valuable time at the hospital and to give the patients a sense of appreciation of what was being done for them, we adopted the custom of exacting a small fee from each one. This did not seem to be a wise policy since the people, having paid actual money, however small the amount, considered that they had conferred the favour rather than that we had placed them under a debt of gratitude. 
Faith.-It so happened that such cases as were necessarily fatal proved so before I became engaged with them, while those to which I was called in time were of the kind destined to recover, and recover they did. This was undoubtedly due somewhat to the faith of these simple people inspired by the fact that their prince had recovered; for in later years, after being in Washington for some time, I found the charm had been broken and the above satisfactory arrangement was much disturbed.

Female Seclusion.-As illustrating this faith and the close seclusion in which the women are kept, a Korean lady actually died rather than see me, though I had been called to the house and she seemed to think that if I simply looked at her she would recover. She could not bring herself to permit a strange man to look upon her and actually died rather than violate the inbred custom of her country. Her tenacity to old custom was fortunate for me since her case was beyond relief.

Vicarious Treatment.-A foreigner once sent his Korean servant to me with a chit or note, reading, "Please give bearer a dose of castor oil." I measured out a liberal dose and compelled the somewhat reluctant coolie to open his mouth, into which the medicine was poured and inevitably swallowed. When he returned his master asked for the medicine and seemed surprised to find that the fellow had brought it inside.

Cholera.-Such diseases as cholera, typhoid and typhus seem to be endemic in Korea and their rav- 
ages in times of epidemic are most alarming. A number of missionaries have had typhus, most of the cases proving fatal.

In the summer of I 886 we had a very severe epidemic of cholera, when it was not uncommon to see three and even five bodies being carried out on a stretcher for burial in a shallow trench; funerals proper being quite out of the question. Burial was necessarily such a hasty matter that the subsequent rains soon washed the earth from the partially decomposed remains. It was a grewsome sight.

The French fathers assisted me greatly at this time by taking quantities of preventive medicine which they used with their people with apparent success. Here again it happened that those who were to die did so before I could reach them, while the others recovered. In some cases death followed so quickly after the onset that the patient had no need of my services by the time I could reach him.

The government officials assisted, and issued instructions regarding the use of boiled water, while they also provided free supplies of lime to be used in and about the drains and under the houses.

Scaring the Demon.-The people, however, think that this disease is caused by an evil spirit; as a result of which belief they declined to put the valuable white medicine under the house where the demon could not see it, but persisted instead in smearing it over the front door and the walls of the house where it could be seen and thus alarm the evil spirit so he would be afraid to enter. 
Others believe that the cramps of cholera are due to the gnawing of rats which have crawled inside a person while he was asleep. This belief was supposed to be sustained by the fact that a village on a hill with a good supply of water was free from cholera, while the name of the village was indicated by the same characters that stand for cat. It was proudly pointed out that as rats fear cats, this village of the cat was practically exempt from the disease.

Now that Seoul is about to enjoy as fine a water system as can be built, thanks to the enterprise of a couple of Americans, cholera will doubtless be shorn of much of its horror. 


\section{XIII}

AMERICAN INTERCOURSE AND JAPAN'S INDEBTEDNESS TO KOREA

OuR early intercourse with Korea was not of a character altogether commendable.

Shipwrecks.-In I 866 the American schooner Surprise was wrecked off the northwest Korean coast and the crew were kindly treated and succoured by the natives, who assisted them on their way into China where they might find foreign ships.

A month later the American schooner, General Sherman, sailed from Tientsin for Korea on a mysterious mission. She passed up the Tatong River at a time when an unusually severe rainy season had caused such a flood that the vessel was able to reach the anchorage at the northern capital, Pengyang, whereas at ordinary times only little sampans are able to cross the bar below that city.

The freshet subsided and the waters fell rapidly so that the vessel was soon hopelessly aground.

A Massacre.-Just what happened is not known, but the white man probably displayed his usual contempt for his yellow brother, and doubtless utterly failed to realize the precarious position of the schooner and her crew. At any rate some altercation arose, resulting in the killing of all the crew and 
the destruction of the vessel. Nothing but the reputed anchor was ever found in after years when foreigners had established themselves in the country.

Grave Robbing.-During the next year, 1867, a German-American, named Oppert, sailed from Shanghai with two armed vessels in quest of the buried treasure for which Korea was supposed to be noted.

The rumours of the existence of this treasure, that led to such a formidable grave robbing expedition, were based upon the custom prevailing in Korea of burying valuable articles with their dead. In explanation of which custom a short digression must be made.

Origin of Satsuma Ware.-The Japanese learned the art of making fine pottery from the Koreans, who were also their teachers in many other useful branches. After the great Japanese invasion of Korea in 1598, General Nabeshima gathered all available specimens of the early Korean pottery manufacture, together with all the potters themselves with their families, and carried them to Japan, where he established the potters as a colony on his native island of Satsuma. Here these exiles continued the manufacture of this ware and taught the art to their neighbours; the remains of this colony may still be seen in their place of exile.

From this small beginning the vast manufacture of exquisite pottery of to-day had its origin in Japan.

Pieces of the genuine ancient pottery made in Korea soon became in great demand, bringing high 
prices in Japan where such were used in the celebrated tea ceremony and were prized as objects of art. The seemingly fabulous prices received for this ware and the fact that it could no longer be produced in Korea, whence even such pieces held as heirlooms had disappeared after the invasion, induced adventurous spirits to open and desecrate the tombs of royal personages buried prior to the advent of the present dynasty, which has reigned for over five hundred years. These graves were rich in the choicest specimens of this ware and the robbers were well paid for their efforts. It thus became noised abroad that Korean royal tombs were filled with riches, gold coffins being mentioned as among the treasures, while as a matter of fact it was simply this pottery that gave the graves their value in the eyes of the Japanese.

Such treaty port rumours were, however, the cause of this formidable expedition, which, by the way, was happily thwarted by the timely arrival on the scene of an American admiral. But it caused great alarm to the natives on their learning that armed foreign ships had come to their country in order to desecrate their ancestral tombs.

Korean Pottery.-On the occasion of my having saved the life of the prince as mentioned in another chapter, my services were rewarded by the presentation of a small piece of this ware. It was brought me in great state by a retinue of palace runners. When the handsome lacquered box was taken from its silken wrappings and found to contain a little gray bowl, 
carefully packed in cotton wool, my amazement must have been quite evident, for it took much difficult explanation before I could be made to realize that this was the most highly prized article the Korean Court could present me. Perhaps my expectations had been raised too high; at any rate it seemed at that time absurd that my three months of arduous and perilous work were only prized at the price of a little empty bowl of what seemed to me to be quite ordinary chinaware. Later, on becoming acquainted with this ancient product of Korea's palmy days, I succeeded in picking up quite a collection of it, usually as the result of the disordered times following revolutions and lootings. This collection has now been acquired by an American gentleman of wealth and artistic tastes, who intends eventually to present it to the Smithsonian Institution, the museum of which institution is now the temporary custodian of the little gray bowl presented me as above narrated.

Our Expedition.-The next American exploit in Korea occurred in $187 \mathrm{I}$, when our minister at Peking came to Korea with Admiral Rogers and a fleet of five of our vessels, the Alaska, Benicia, Colorado, Monocacy and Palos. The object of this formidable visit was to obtain a reply to a letter supposed to have been forwarded to Seoul by the Chinese government for us, dealing with the subject of the destruction of the General Sherman, for which grave action we had as yet secured no redress and not even an explanation. A further object incidental to the mission was to be the arrangement of some basis of 
negotiation for the establishment of treaty relations, after the manner in which Commodore Perry had opened up Japan a few years previously.

Doubtless the Koreans had never received the letter in question, since China may not have considered it to her own interests to forward it. At any rate they had had a very disagreeable time on the occasion of the last visit of our flag, when borne by the General Sherman, as well as on the occasion of Oppert's visit. Further, they did not wish to be opened up after the manner in which Japan had been obliged to unlock her doors. They asked only to be let alone. So that when our ships began to steam up the river against wind and tide and the capital seemed threatened, the forts on the great Kangwha Island at the mouth of the river opened fire upon the intruders.

Our Korean War.-Forces were promptly landed from our fleet and the poor old forts were stormed from the ships. The casualties on our side were slight,-Lieutenant McKee was killed as he scaled the parapet in advance of his men, followed closely by the present Admiral Schley. Two of the men were killed and ten were wounded, while the Koreans lost two hundred and forty in killed, and twenty wounded were captured. None seem to have escaped.

The old matchlocks were of little use against modern weapons, and though our men were surprised at finding clumsy breech-loading cannon in the forts, these were placed so badly as to be of little use. The defenders fought well and valiantly and did not desert 
their posts, but it was a useless slaughter and one from which no good results ensued, and of which we have not since been proud.

The French had previously made a similar and fruitless attempt, from which they were driven off with less loss to the natives. This had heartened up the Koreans somewhat and caused them to be, to a certain extent, prepared for our onslaught.

Up Salt River.-The French called this Han River the Salle, which our people pronounced "Salt." This ineffectual attack and needless expenditure of lives was therefore mentioned as the expedition " up Salt River," and for some time thereafter a futile attempt of any kind was apt to be designated as going up Salt River.

Our Treaty--However, after years of effort, we finally succeeded in 1882 in concluding the first of the Western treaties with Korea, thus bringing her reluctantly from her coveted seclusion into the limelight of foreign relations, and giving every one a claim to interfere in what she so long considered her own affairs.

Korea has taken that treaty to mean just what the words say, while we seem to have utterly disregarded the solemn promise we therein voluntarily made, that we would lend her our good offices should she be oppressed by a third power; thus breaking our faith with a people who trusted us implicitly, and who consented to the opening of her doors on this our guarantee of friendly aid. 


\section{XIV}

\section{AMERICAN COMMERCIAL INTERCOURSE}

AMERICAN business men have received the best of treatment in Korea. Prior to the advent of the recent Russo-Japanese war, Americans were in the lead in the large enterprises of that land involving development work and the handling of large sums of money.

Mines.-One of the most extensive and successful gold mining properties in Asia is that of the American concession in Korea, which employs over half a hundred white men and some thousands of Asiatics in the operation of its mines and mills, its electrical development, transportation, and all the many accessories necessary to the successful conduct of so large a property.

Railways.-Americans built Korea's first steam railway, which was sold to the Japanese, and is now in successful operation with American equipment over a standard gauge track and a ten span steel bridge of two thousand feet in length. Although this road is but twenty-five miles long, connecting the capital with the port of Chemulpo, it was the forerunner of the extensive system of railways now built and in process of building by the Japanese in Korea, and thus set the standard as to gauge and 
equipment. The roads in Japan were patterned after those of England and built, in the first place, with English assistance; the result is that they are unsatisfactory, being narrow gauge and light. I have heard prominent Japanese deploring the fact that they have not the same system in Japan that they are conducting so satisfactorily in Korea, but it would be a great task to change all the roads of Japan at this time.

The first Korean electric road was also built by Americans in connection with a lighting plant, the whole constituting one of the largest single electric plants in Asia; the success of which is so marked that extensions, made for providing new power, are necessary from time to time, and the demand for light and power generally exceeds the supply.

First Electric Plant.-This was not the first electric plant to be established in Korea, for in 1885 one of the fine plants of the Edison Company was installed by men sent from the inventor's own laboratory for the purpose. In getting a fine electric plant at this early day the Koreans wished to profit by the experience of other people, and since this was the latest and best light, they skipped the gas period and secured the highest product of modern experience in light development.

Water-Works.-The firm that built and now owns the present electric plant in Seoul, is about completing a most necessary water-works system for the city, on agreements executed long before the recent war placed all such matters in the hands of the Japanese. 


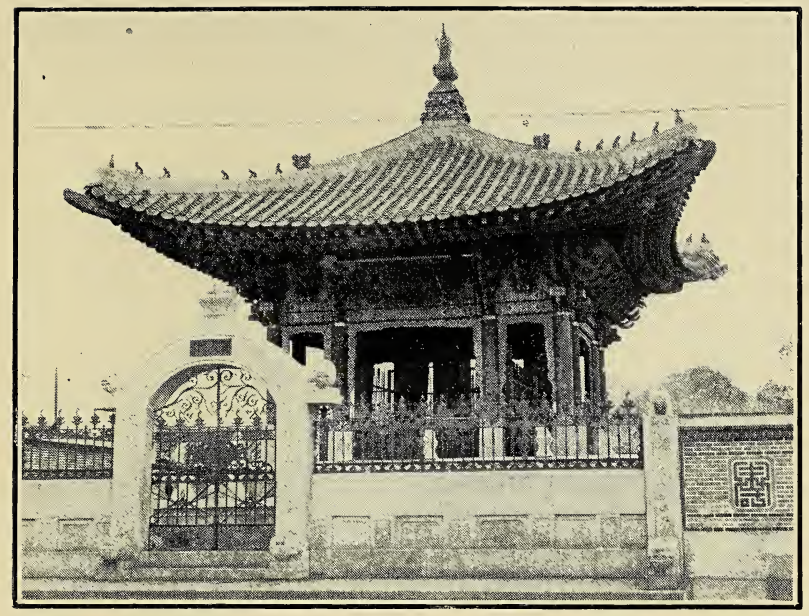

A STREET-SIDE TEMPLE IN SEOUL

Trolley Wires Show in Front

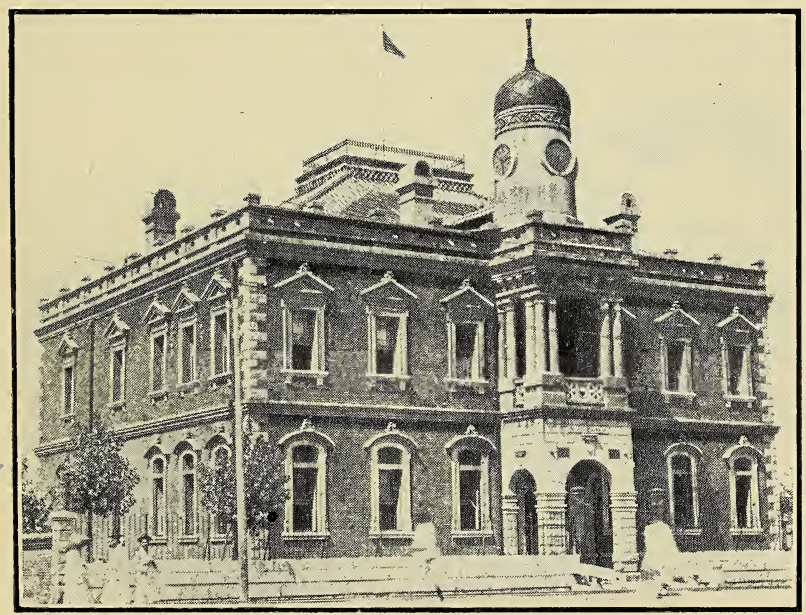

SEOUL OFFICES OF THE AMERICAN FIRM CONTROLLING THE ELECTRIC PLANT AND WATER WORKS 

This plant is so extensive as to provide for all probable future wants, and although the supply could not well be better, a complete filtration system is being installed for greater perfection; so that as in the matter of light the Koreans passed from the tallow dip to electricity, in the matter of a water supply they will jump from wayside wells to mountain water carefully filtered and delivered at the door or in the houses.

While these enterprises were American in their inception, English money had to be secured for their proper development and execution, both in the case of the gold mines and the railway and water-works operations, and our English cousins thus profited by our initiative.

We once did quite a business in cotton goods, though the bulk of this trade was with England, until Japan began to quietly take it for her own mills, as was quite natural as a result of their success in cotton manufacture.

Kerosene.-Our kerosene has had a hard fight with the Russian and Lankat oils which were often offered for sale by Japanese merchants in the once used tins and cases of the American product, while the lettering displayed on the American packages was actually imitated on spurious ones containing the inferior oil.

Through the skillful management of the local agent, this underhand work was largely circumvented in a straightforward and successful business manner, so that the sale of the poorer oils-which the natives 
did not really want-was materially checked, and our own product kept the field.

Trade-Marks.-In a land where trade-mark registration was unknown and where all manner of deception might be practiced, such sale of spurious goods was most easy. In attempting to secure protection for the sale of the product of the British and American Tobacco Company, I secured an order forbidding the sale of spurious cigarettes and tobacco in the once used boxes of the American company, and when this order was promulgated, somewhat to my surprise I learned that it carried a death penalty for infringement. This served better than a trademark restriction so far as the natives were concerned, but scarcely reached the Japanese merchants who were the chief offenders.

Americans Lead.-Formerly American visitors were usually struck with the unique situation in Korea where their own people were seen to be in the lead. To those who had made the trip by way of the Suez Canal and had visited that wonderful belt of commercial colonies under British rule, the sight of which makes the British blood in American veins tingle with pride, this condition of affairs in Korea was particularly impressive. While the American element and American interests were something of a negligible quantity in the bustling marts that mark Britain's progress from Egypt through the Indian Ocean and the China seas; in Korea everything seemed to be American and our influence to predominate, quite reversing the situation as com- 
pared with the other foreign settlements of the Far East.

This agreeable sensation will not now be experienced by Americans who may chance to visit Korea. Japan needs the country for her growth and development, and having won the right, by the verdict of war, to do about as she pleases with the peninsular people, she is doing it with a vengeance. American vested rights will have to be respected, but these will gradually drift into Japanese hands, until conditions will correspond with those pertaining in Japan. It is and will be-Korea for the Japanese.

Our Mistake.-It did seem unaccountable that in giving up our advanced position in Korea, we should have received nothing in return. Within a few days after the Japanese announcement, in November, 1905, that they had secured an agreement from the Korean government amounting to suzerainty, our legation was withdrawn from that country without giving the Koreans a chance to be heard on the subject, and without waiting for England, the ally of Japan, to make the first move. In fact, we forced England's hand in the matter.

This was such a tremendous advantage to Japan, compelling as it did a similar course on the part of the other treaty powers, that it would seem to have been practicable to obtain from Japan almost any concession within reason in consideration of our adopting such course. We might at least have been able to so arrange for our withdrawal as to have in a measure preserved our faith with the Koreans, even 
though the present result may have seemed inevitable; we might at the same time have secured some advantage in a commercial way, or in the matter of a naval base, which we would now be able to hold as an asset in any diplomatic trade that post-bellum conditions should make necessary.

England's Method.-We are sometimes called a nation of traders, but when it comes to international agreements we are far from being adepts at bargaining. The British never give up an advantage without securing some consideration in return, and they have been known to magnify a petty privilege in order to have something with which to trade, and then to arrive at a good bargain in the dicker. For instance: In I885 they seized the Korean islands, known as Port Hamilton, without right or provocation, and simply because this group was thought to be a valuable place for a naval station and liable to fall into the hands of Russia. When international pressure for restitution became troublesome and it was incidentally learned that the harbour was not so desirable as it was thought to be, the place was given up. In making restitution, however, the British government very cleverly surrendered the property to China, on condition that she prevent it from falling into the hands of a third power. Japan had not yet pricked the bubble of Chinese dominance in Asia and she did not cut much of a figure in any such agreement, while China moreover claimed a sort of suzerainty over Korea. Japan effectually silenced this claim in her war with China of 1894 , but in 1885 
England was on most intimate terms with the great Middle Kingdom and had not yet embarked upon her recent strange course of backing up a commercial rival who should wrest from her the great China trade with which her commercial supremacy in Asia is so closely linked.

In handing over this island harbour to China, England prevented it from falling into the hands of her then rival, Russia, while she gratified China and silenced the protests of Korea. The result was probably worth the trouble, especially since the property was found to be practically useless for the purpose for which it was intended when occupied.

In our action in handing over Korea to Japan, on the contrary, we seem not to have appreciated the advanced position won by our own citizens for our commercial interests, and incontinently handed over, for no apparent consideration; a hard-earned and profitable commercial situation, for the retention of which England would have made a strong fight and which she would probably not have abandoned except for due consideration.

Possibly the policy pursued in this instance, in case there was any policy, was that of favouring our general trade with Japan, upon the supposition that Korea under Japanese rule would become more of a consumer of general imports and that our trade with Japan, as the distributor, would increase.

The Japanese, however, are distinctly a commercial and manufacturing people and they will do their utmost to produce what is wanted in Korea and 
adjacent lands, while as it was, each American enterprise constituted a centre for the introduction of American products pure and simple, which, with the development that each year brings, would greatly have enhanced our trade with the eight or ten millions of Korea's population. 



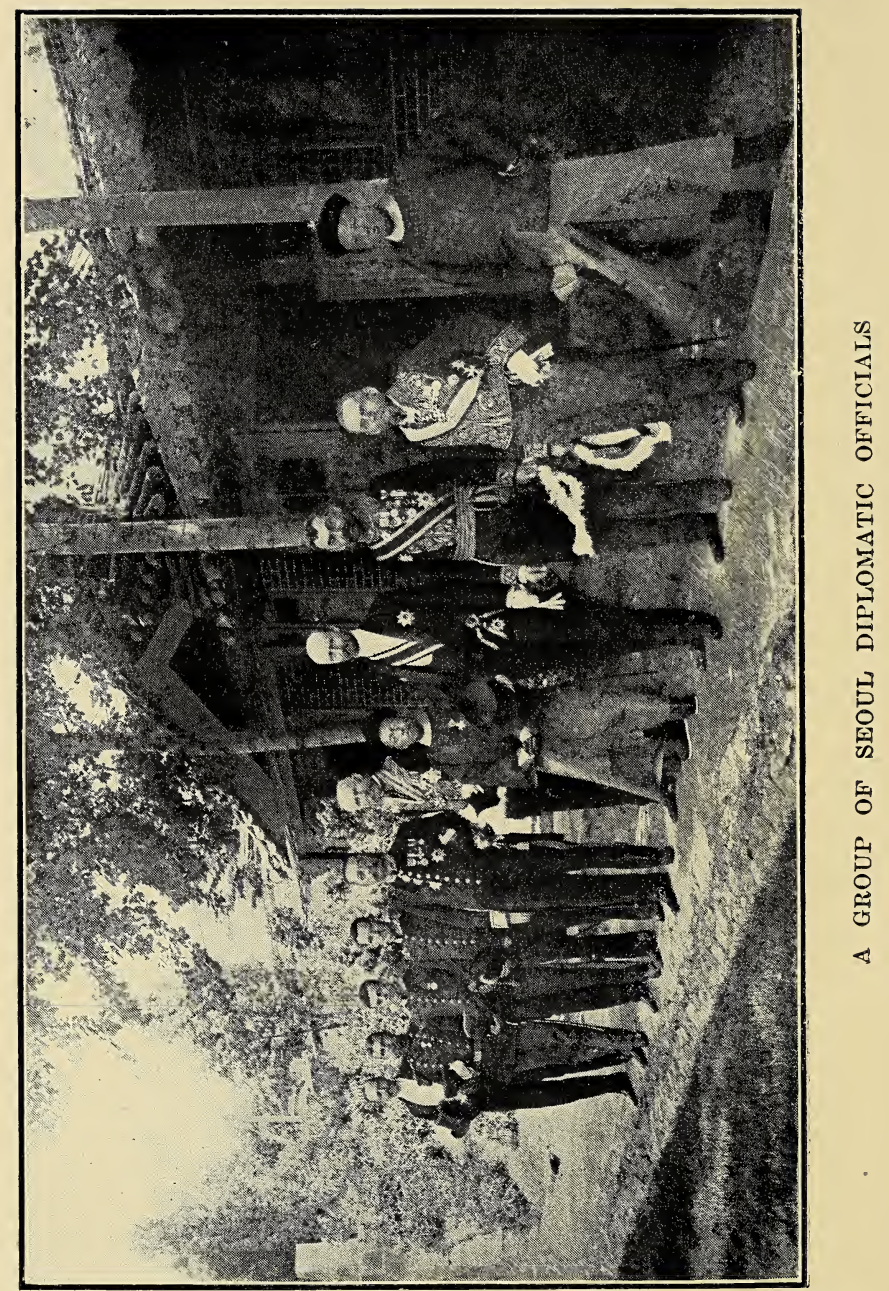




\section{XV}

\section{CONSULAR AND DIPLOMATIC INCIDENTS}

I ONCE had a guest at the American Legation for a few days during one of our periodic excitements, when it seemed to be my particular province to save the lives of certain native officials whose posts were desired by rivals.

Alter leaving Korea my friend wrote me that his little experience at Seoul had convinced him that " a diplomatic career might be checkered but never dull." His remark very aptly described ordinary conditions in that little empire.

Marine Guards.-In other chapters mention has been made of the internal disturbances common to the land, arising in some cases to the dignity of revolutions. During the period of excitement attendant upon the Japan-China war of 1894, and the consequent disorder that ensued, resulting in the assassination of the queen of Korea and the escape of the king to the Russian Legation, our own legation with others, was furnished with a guard of marines from one of our respective vessels stationed at Chemulpo. The same was true during the inception and progress of the Russo-Japanese war. In fact the summoning of the American guard in December, 1903 , followed as it was by similar action on the part of other legations, was reported as being the first real intimation to the world 
that war was imminent. Telegraphic reports were to the effect that the summoning of these so-called " mosquito armies" made quite an impression at St. Petersburg where accurate information seems not to have been always at hand.

The arrival of our own guard on that particular occasion caused not a little consternation, for while the request had simply been that a ship be stationed at Chemulpo prepared to land a small guard if necessary, it seems to have been thought better to send a detachment of one hundred marines from the Philippines on a transport. While twenty-five men might have been landed with little comment, the immediate landing of one hundred, for whom quarters had to be provided outside the legation grounds, since they could not remain on the unheated transport in zero weather, caused criticism as well as comment; and under Russian influence this developed into actual opposition, so that an attempt was made to prevent these men from marching into the city. This was a most unusual thing, for before that time and very soon thereafter, the presence of an American guard was about the most desirable thing in the estimation of the native officials, seeming to be a pledge of peace and of safety to them. In this case the men had started for the city before the opposition was made known and there could be no talk of turning back; therefore such opposition, not representing true Korean opinion, could only be ignored. The secretary of legation was accordingly sent outside the walls to meet the guard, and being a man of good 
sense and judgment and abundant in resources, he could be depended upon to take the proper course under any circumstances that might arise. When an armed sentry stepped out into the city gate and attempted to bar the way of the troop with his musket, the secretary brushed him aside as though he were a coolie with a stick and the troop marched through, thus closing that incident, for in a few days the ruler was showering presents upon the men of the guard for saving some of his palace buildings next to the legation, in a severe fire that came near wiping out both legation and palace.

Palace Neighbours.-The very proximity of the palace helped to make things a little less dull at the legations. Formerly the extensive palace grounds and buildings at the opposite side of the city were used, but after the assassination of the queen, the king built a new home for himself adjoining the American Legation, which he finally surrounded on three sides, so that we were the closest of neighbours. When I bought and fitted up a summer place at the seaside, near Chemulpo, he sent officials there and had them buy up a whole hillside for the purpose of building a summer palace adjoining my grounds, but wars prevented that project from being carried out.

Refuge and Entertainment.-But even when there were no wars or revolutions to create disorder, some intrigue between parties was likely to furnish excitement, for the Koreans are past-masters at intrigue and seem to imbibe it with their mother's milk. As the result of some such intrigue some liberal official 
would present himself from time to time at the American Legation for refuge. So many of these better class officials had been to America and there imbibed liberal ideas which they would try to put into force in their country and thereby get themselves into trouble, that we could not well turn them from our doors, especially as we knew that a few days would suffice for calmer councils to prevail and resentment to subside, while valuable lives might thus be saved. I remember being awakened one night to receive a pencilled note written on a scrap of paper by a Korean official who had most creditably represented his government in America. He was in danger of his life and begged the protection of our residence for a short time. His quaint note ran thus, "Dear Minister, I am very afraid of this world, won't you let me visit you for a few days?"

In the early days before the railways, there was no proper hotel in Seoul and guests would usually bring some sort of introductory letter and secure entertainment at the legation of their country. As there were more A mericans than other Western foreigners present and as we kept a detached house fitted up for the entertainment of travellers for many years, a guidebook published in Europe had an entry under the head of hotels in Seoul- "Guest House, American Legation." The hospitality of our official establishment had therefore become an international feature in connection with Korea.

Baby Eating.--In the early days one of these periods of excitement started with a malicious 
rumour, circulated by certain Chinese in Seoul, to the effect that foreigners were in the habit of devouring native children and of using their eyes to make medicine. It was a rumour similar to this that caused the fatal riots in Tientsin in the early seventies, and as my then predecessor at the legation, the American minister himself, was credited by these Chinese with having roast baby on his table, he was obliged to summon a guard for his protection.

As a rule there was little question as to our personal safety since Americans were favourites with the people, but all these native disturbances helped to make life checkered and quite the opposite of dull; while life at any court, with its more or less intimate connection with other centres of political interest and initiative, possesses a charm peculiar to itself, even if that particular court chances to be an insignificant one.

Varied Functions.-The office at Seoul for many years carried the rank of minister resident and consul general, and even when I had been promoted to be envoy extraordinary and minister plenipotentiary it was difficult to distinguish between functions that were consular or diplomatic.

It thus befell the American representative, by virtue of the extraterritorial powers conferred upon his nationals by treaty, to legalize marriages, to record deaths, to transfer property, to execute deeds and keep a record of all real estate transfers, to settle estates, to sign invoices and attend to all manner of shipping matters including the purchase and sale of 
vessels, and to settle disputes if possible or where impossible, to open court and act as judge in all matters concerning the rights and privileges of American citizens.

A Murder Trial.-On one occasion it fell to my unhappy lot to open the first court we Americans had held in Korea, for the trial of a fellow citizen on the charge of murder. Further, I had been obliged to apprehend and arrest the poor fellow charged with the crime, and to prepare a jail and hire a constable, though the State Department had just forbade my incurring any such expense. I may add, however, that they promptly honoured the drafts for this expenditure once it was necessarily incurred.

In this case I had to be prosecuting attorney and judge, though I was allowed four associates on the "bench." One of these was an American lawyer of reputation who had practiced before the Supreme Court of the United States and we were at least assured that things would be done properly and that there would be no miscarriage of justice.

The man was convicted, and the death penalty having been abolished in the federal courts, he was sentenced to life imprisonment. For three years he was kept on the legation grounds in a small building occupied by the constable's quarters and the jail. He escaped once but got so cold and hungry that he was glad to be apprehended and brought back to his warm quarters and the constable's well-supplied table. In time a bill was passed through Congress permitting of his being sent to San Quentin, 
California, whence he was pardoned in time to allow him to be present in San Francisco on that memorable I 8th of April, 1906, when it seemed to him, as he wrote me, that he had gotten away from his condition of living death just in time to see the end of the world.

This trial was really a most difficult matter to arrange for and conduct, especially for one who had never been around courts of justice and who possessed no technical knowledge of law and legal procedure. We had none of the necessary forms or blanks to make legal process easy, necessitating a vast amount of work in arranging for the petty details of the case. Then it was a rather discomforting thing to have to deprive a fellow man of his liberty by the stroke of a pen, especially since his place of confinement was to be one's own dooryard.

A Service a Necessity.-This incident shows the necessity to us of having a regular consular service, with certain legal and linguistic requirements made compulsory for candidates who hope to serve in countries where we enjoy extraterritorial rights. This legal difficulty has been somewhat relieved in China and Korea by the establishment of our court at Shanghai, yet some legal knowledge seems most necessary for consuls in those countries.

Plan for a Service.-When serving with the Korean Legation in Washington in I888, our Naval Academy was graduating classes containing more members than could be provided with positions in the navy. Quite a large proportion of these 
graduates were therefore obliged to give up the calling for which they had been prepared and go back to civil life. Some of these bright young men came to me to see about securing employment with the Korean government, which brought their condition to my personal knowledge. This suggested a plan which later years of observation only served to impress more strongly upon my mind, and I shall digress a little to mention it for the first time in print.

It is that a certain number of the graduates of Annapolis should be allowed annually to elect to enter the consular service. This service would thus secure picked young men of good health and habits, of good education and of gentlemanly manners and deportment, while they would be familiar with polite society and well qualified to attend to the social duties which would devolve upon them, the importance of which is not always appreciated by those desiring such positions for themselves or their friends. Moreover, their education would be in line with their future duties. They would be familiar with shipping matters which occupy so much of the time of a port consul; they would be qualified in at least one foreign language; they would know the rudiments, at least, of common and international law, and they would presumably represent us in a dignified, discreet and gentlemanly manner, for a finer set of men than those composing our force of naval officers would be hard to find anywhere.

Of course now that the demand for officers for our navy seems greater than the supply, perhaps it is late 
to mention this plan; still it is not impossible to enlarge the capacity of the academy, and the very fact of this privilege of selection being open to graduates might make the naval education offered to our young men seem all the more attractive. It is a plan that would certainly improve present conditions, and one that could not well result in disaster.

All that has been said of Annapolis probably applies in a great measure to West Point, but the writer has had little personal acquaintance with the army.

Missionary Difficulties.-A body of one hundred and fifty missionary men and women, with their large native following, brought plenty of work to the legation; for while the simple and kindly natives accept Christianity readily, the official class were apt to let pass no chance for personal gain, and the frugal habits taught by the missionaries usually resulted in bringing about a better worldly condition to their followers, making them consequently the more liable to magisterial attention. In interfering with these native Christians the officials would sometimes overstep their rights and give good cause for the foreign teacher to take up the case for his native pupil. Sometimes, also, these cases seem to have been welcomed by some of the more indiscreet among the missionaries, who may have thought that the legation officials were in need of stimulating excitement. At any rate, mission cases were almost always " on the docket."

Promotion of Commerce.-It seemed to be the province of the American representative to further 
the business interests of his nationals, at least it seemed to be the case in Korea where I chanced to occupy a rather unique position of influence with the court. At a time when I was merely secretary of legation, I was in the palace one night, where previous service as physician and adviser made me a somewhat familiar figure, when the subject of increasing the interest of America in Korea came up. I suggested that the best way to increase this interest would be to enlist American capital in the development of the country. This led to quite a long discussion and resulted in my carrying away a concession for a gold mining district. Not knowing of any one who was especially anxious to have, or able to handle, such a property, I made out the concession in the name of an American business man in Japan whom I knew to be interested in Korea and whom I respected highly. $\mathrm{He}$ was very much surprised at finding such an important document lying on his desk with his morning mail, as he had had no premonition of the fact that he was to be made the partner of a king in a gold mine. He soon disposed of his concession to other Americans who have made of it one of the noted commercial successes of Asia.

Mines.-The grant of this concession brought trouble to the poor Koreans, for every other representative in time demanded a mine for his people. After considerable delay each was given a mining grant, but the American was the only successful one ; due to the fact that, as the result of a long train of cirçumstances, it had become known to me exactly 
which district was considered the richest by the natives, and it was this district, twenty-five by thirty miles in extent, that I named in the concession.

Assassination Promotes Railways.-On another occasion the distress produced by the awful fate of the queen actually led to the grant of a railway concession to an American, in the following manner:

While serving as chargé d'affaires I was called out of a sick-bed at dawn of an October day in 1895, by an urgent request from the king that I come to the palace where serious things were taking place. I called for the Russian minister on my way, and together we repaired to the palace, arriving in time to see the blood-stained miscreants leaving after having murdered the queen. Following this event, which has caused the Japanese government great regret, the palace and its occupants were closely guarded by the Japanese, notwithstanding which the king and crown prince escaped in disguise and fled to the Russian Legation, in February of 1896 , where they remained for a year and a half.

On the October morning when I went to the palace six of the highest officials in the government, all favourable to the king, took refuge in my bedroom and my wife dressed the wounds of those who were injured. These men were kept as refugees at the legation until, upon the escape of the king to the Russian Legation, they were made the cabinet, with my old friend the former minister to Washington as prime minister upon my own recommendation. Having done so much for them they naturally wished 
to return the compliment and when I asked for a concession for a railway to connect Seoul and Chemulpo it was granted. This was made out in the name of the man to whom the mining concession had unexpectedly gone, for while he did not seem to care for mines, he did want a railway concession. $\mathrm{He}$ had been requested a few years before to come from New York to Seoul to negotiate for the construction of railways, and after some weeks of preliminary discussion he was about to close up the negotiations when the Chinese minister heard of the matter and peremptorily stopped the whole proceeding, thus greatly retarding progress in Korea and causing the American a grievous loss of time and money, for which there seemed to be no redress. It was a matter of pride, therefore, on my part, to secure this satisfaction for my fellow countryman, while the road itself seemed an absolute necessity, as it has since proved to be.

Electric Plants and Water-Works.-Other enterprises in which it was my good fortune to assist our people were electric lighting and trolley plants and water-works.

A horse railway had been under consideration for some time, but a Korean who had served in Washington and had seen the electric road just then completed in that city, which was one of the first to be successfully operated in our country, persuaded the ruler that, as in the matter of the electric light, they should profit by our experience, skip the intermediate stages and get the best and latest development. An 
electric railway was therefore decided upon and the contract for construction was given to an American firm then operating in Korea, together with an agreement covering electric lighting and water-works. Later it devolved upon me to foreclose a mortgage upon this railway property, which resulted in making the Americans joint owners with the ruler in this trolley line, which has since developed into a most popular and profitable enterprise.

The water-works franchise was a matter in which I had taken a special interest ever since the days of my medical service in the cholera epidemic. I had frequently seen people taking their drinking water from roadside wells, the walls of which also formed the wall of a sewer flowing alongside. This enterprise did not promise so well as some of the others, though it was more greatly needed, and it was a great source of gratification to know that finally the people were to have mountain water brought right to their doors, after I had been urging it upon every possible concessionaire who came along for years. The plant is now nearing completion and the supply of water will be abundant and as good as the best.

All these varied enterprises afforded ample occupation, for with the rivalry between individuals, and the strife between the various representatives to see that no other nationals got more favourable terms or greater rights than his own, one was kept on the alert continually. Then when a concession was allotted the trouble had only begun, for there was the enforcing of its terms before officials who might have 
been newly appointed and did not approve of letting in the foreigner to such an extent. Sometimes riots would occur, as in the case of the early days of the trolley, which had excited the enmity of the carriers' guild so that when a severe drought occurred these people convinced the populace that the dry weather was due to the electric wires, and a riot ensued. The same was true when a child was accidentally run over and killed in the early period of the operation of the cars in those crowded streets.

A Promoter.-It was a somewhat unique position in which I found myself upon leaving Korea after twenty-one years' residence there, having to my credit the introduction of the following new departures, all of a useful nature :-Protestant missions and Western medical science; modern mining on a colossal scale; steam railways; electric trolleys and water-works, all of which were left in a successful going condition.

Entertainment.-One of the pleasantest duties of our official life was the entertainment of visiting Americans. Seoul was so far off the beaten lines of tourist travel that we were not overburdened, while those who had the means and the persistence to come so far, were usually interesting and well worth meeting. During the early days when hotels were such only in name and the " Guest House, American Legation" was given as the stopping-place of the guidebooks, the legations were the natural stopping-places for visitors.

Legation Buildings.-The other powers each had more pretentious buildings for the housing of their 
representatives in that land than had our own government. We continue to occupy a quaint but picturesque bungalow, once the home of a high native dignitary. It is situated in a quarter occupied largely by legations and the new palace. It has extensive, wooded grounds, with large stretches of greensward, making a comfortable and artistic compound, though the building is one that hardly does us credit in comparison with the massive structures erected by the other countries. However, as diplomatic representation is now at an end and at least one of these pretentious legation buildings has been sold upon the withdrawal of the minister, it may be considered well that we did not build, though the British buildings are just as serviceable for the staff of the consulate general as they were for the minister, and our own consul general should be as well housed as his colleagues.

A Guest.-Sometimes we would be called upon to entertain people who proved to be somewhat peculiar, as in the extreme case which follows. We had done our best to be agreeable to a guest during his week's visit and supposed we had succeeded, for he seemed very anxious to do something in the way of returning the compliment. Upon his insistence we finally commissioned him to send us a small article from Japan, giving him the exact price for the purchase, when he seemed lost in thought and finally announced that there would be two cents postage on the article. The postage was thereupon prepaid. 
A Strange Career.-It is a rather strange termination of a career begun as a medical missionary to have it end as a minister plenipotentiary; yet the change was so gradual as to be little noticeable, beginning with a preliminary service with the Korean Legation in Washington, and then step by step from the lowest post in our own service up through all the grades below ambassador. As this service was continuous and all in one country, and practically coincident with the whole period of that country's diplomatic relations, it enabled one unconsciously to acquire a useful familiarity with conditions, such as would be difficult to secure in a period of shorter service. It also enabled me to hold commissions consecutively under Presidents Harrison, Cleveland, McKinley and Roosevelt.

Minister and Consul.-Here in America it is sometimes amusing to see how confused some of our people are by the term minister as applied to a government official. Consul is a term readily understood, but the title minister seems usually to be taken in its clerical and religious sense.

Some time ago I was introduced by a friend to an acquaintance of his as lately minister to Korea. The man remarked in a very patronizing manner, "Yes, of what denomination ?" I replied that I was a Presbyterian, not wishing to go into details. He then asked if I had "done any good over there," to which I replied that I had tried to do my duty. He then asked if I had succeeded in " converting any of them heathen," whereupon my friend interposed and said 
that I was our government minister, and the man demanded to know what our government meant by sending ministers out there when Church and state were separate with us. To this my friend explained that he meant something like consul only higher, and the instantaneous change in the man's manner was quite amusing.

In a land where Christian missions occupy such a prominent place, it was perhaps just as well that the representative should have been connected with the same work, since the protection of mission interests occupied so much of his time.

The Higher Law.-People with convictions so strong as to lead them to the uttermost parts of the earth are apt to become devoted to one idea exclusively, and this devotion renders their conduct at times somewhat embarrassing. One of my colleagues had a citizen among the missionaries who fell out with the native officials and later disagreed with his own representative. When ordered to pursue a certain course the man objected on the ground that he was subject to a higher law and to the heavenly court. My friend replied that as he had not jurisdiction in that court he could not well listen to an appeal and must insist upon compliance with his orders so long as the missionary remained within his jurisdiction.

Strange Requests.-Our consulates and legations are continually in receipt of requests from enterprising merchants at home regarding possible markets for our productions, and some of these requests are at 
times amusing because of their inappropriateness ; as for instance when a firm of manufacturers wrote to request information in regard to the market for materials for the upholstery of Pullman cars. Some years later we had the useful jinrickisha, which being drawn by a man is sometimes called the "pull-man car" of the East, but at that time we had not even this distant approach to our luxurious wheeled palaces, upon which one might base a report.

A Hoax.-At another time a sensational story published in our home newspapers resulted in so many requests that I was obliged to issue a circular contradicting the whole thing. The papers would not make any correction but continued to publish the story which was translated into foreign languages and thus brought similar requests to the other legations in Seoul.

I refer to the story of the fictitious "Emily Brown," who was described in the article as being the daughter of an American missionary and married to the emperor of Korea.

Although no shadow of foundation ever existed upon which such a narrative could be based, it was so cleverly written, bringing in names of real places and living participants in the ceremony-myself among the number-that it was taken by most people as truth, and was so much relished by the newspaper publishers that they flatly refused to suppress or contradict it.

One result of the publication of this wild yarn was that the American Legation was deluged with appli- 
cations for positions at this semi-American court: Applications covering the post of nurse-wet and dry ; physicians in ordinary and extraordinary ; lady's maid ; governess ; coachman ; cook ; and even dentists made application for one of these court positions.

So greatly was this story relished that it has been resurrected, furbished up a little, and published recently since the abdication of the emperor of Korea, showing poor "Emily" in distress, riding astride on a diminutive donkey, wearing no veil, and in an altogether impossible situation for one supposedly holding the rank conferred upon her by her newspaper parents. However, it seemed to suit the vaudeville taste of the rag-time portion of our great newspaper public.

Taken for Vaudeville.-That reminds me that a party of Korean diplomats under my escort were once taken for a vaudeville troupe. It was in 1888 when the first legation was en route from Korea to Washington. We stopped rather late in the evening to have our dinner at Cheyenne, dining-cars in that region being at that time a thing of the future. The manager of a vaudeville troupe that were our fellow passengers on the train, came up to me in a fraternal manner and asked where I was going to show next. I explained carefully the nature of my party and seemed to have some difficulty in making him understand that this was a diplomatic party en route to Washington where they would be received by the president.

We separated for our meal and met afterwards on 
the way to our respective cars, when my new acquaintance showed a most friendly disposition and a desire to make amends for any seeming obtuseness, for he offered, if we would stop over Sunday at Salt Lake, to give us a benefit. 


\section{XVI}

\section{POLITICAL CHANGES AND PROBABILITIES}

DURING twenty-one years' residence in Korea we saw great changes in the political aspect of affairs. During this time three great overturns took place. In 1884 the haughty Chinese drove the then inconspicuous Japanese so precipitately from the land that they left their dead on the streets to be devoured by the dogs.

China-Japan War.-This was a costly victory for China since it convinced the Japanese that they must come to a final understanding with their great neighbour regarding the peninsula over which each had claimed suzerainty for centuries. Without exciting comment, Japan prepared for this contest during the next ten years, and to make assurance doubly sure, while the authorities were actively engaged in preparations at home, their agents were all through China in disguise gathering such exact information as to that country and its resources as had probably never before been collected even by the Chinese themselves.

When she was all ready to surprise the world with the perfection of her military organization and arrangements, the assassination of one of her Korean protégées in Shanghai seemed likely to furnish the 243 
necessary spark for kindling the fire, but a better method of kindling the blaze appeared in the results of an unusually severe insurrection that had broken out in Korea itself.

This outburst was simply a markedly vigorous protest against official oppression, such as is common in Oriental countries, but as the trouble grew and the very capital seemed to be threatened, the official chiefly at fault, fearing for his own safety, applied to the Chinese representative for assistance. The request was granted, largely, as was reported at the time, owing to the clever instigation of the then secretary of the Japanese Legation. Troops were therefore sent from China for the suppression of this insurrection and in sending these troops China violated the agreement she had entered into with Japan after the little revolution of ten years before, which agreement was to the effect that thereafter neither country would land forces in Korea without first notifying the other. Ten years of quiet and of paramount influence in the peninsula, during which time the Chinese representative had lorded it over the Japanese minister in common with the ministers from other countries, had all served to lull him into forgetfulness of this agreement, and China proper had no more idea at that time that Japan would dare to make war upon her than had Russia ten years later.

I chanced to be dining at the Chinese Legation the night that telegraphic news was received of the despatch of a Chinese force. Possibly the jubilance of 
the Japanese present may have served to accentuate the gravity of the crisis; at any rate it soon became evident that a grave crisis was at hand and the dinner broke up in more or less gloom.

The Chinese troops landed and were later given battle at Asan, while the next contingent-on the British ship Kowshing-were killed or captured when their vessel was sunk by the Japanese as she was approaching her anchorage near Asan.

Japanese Preparedness.-The Chinese made their first landing on June 8, I894, and the Japanese, as though standing by all ready for action, landed marines on the Ioth and began to fortify the region around Seoul, while awaiting the regular troops which arrived a few days later.

While the Japanese thus secured the most important positions, the Chinese waited until the battle of Asan on July 28-29, when the Japanese were all ready and strong enough to go out and look for them. The Kowshing was sunk on July 25 th, thus depriving the Chinese of reinforcements and moving the scene of hostilities to the north. War was not declared until August Ist-some time after war had actually begun.

The order and preparedness of the Japanese at this time was simply marvellous, because it was so entirely unexpected. It was the first intimation the world had of the excellence of the Japanese military organization. Yet we, who knew China well, had no doubt that when China's millions began pouring over the Yalu, they would drive the Japanese into 
the sea. Even the Chinese residents, official and commerical, seemed most to fear their own unorganized army, and the merchants closed their shops and followed their representative in his precipitate flight.

A new order had come into force, however, for which the previous opinions of the world were unprepared, for with the battle of Pengyang on September 15-I7, and the naval battle of the Yalu on September 17 th, the war was practically over. Japan had taken a new place among the nations and the showing up of China's weakness was like the opening of Pandora's box in the troubles thus let out upon Asia.

Diplomatic Blunders.-The brilliance of Japan's feats at arms was counterbalanced by her blunders in attempting to reorganize conditions in Korea, beginning with such interference with personal liberty as regulating the size of sleeves, the colour of clothes, and the method of wearing the hair; ending with the assassination of the queen in October, 1895, and the reversion of paramount influence to Russia.

Cause of Russian War.-This new position of Russia in Korea taken in connection with the wresting from Japan of her fruits of victory in the Liaotung Peninsula with the subsequent occupation of that region by Russia, seemed to convince Japan that she must come to an understanding with Russia as she had with China, and the next ten years were devoted to most strenuous preparation for the inevitable. 
Russia's Representatives.--The Russian government had for many years as representative in Seoul, a most cultured man, who, with his amiable wife, was completely devoted to the gentle Koreans, whom they actually seemed to love. Had this man remained at that post, with his suave and compromising ways, it might have been more difficult to find a cause of war in Russian operations in Korea, faithful as he was to his own government while doing all in his power to meet opposition in a fair and sufficiently yielding manner. That I an not mistaken in holding this opinion is shown by the remark of a high Japanese official who said to me that it was a fortunate thing for Japan that this man was recalled, since with him at the Russian Legation, sending accurate accounts to St. Petersburg, it might have been difficult to bring about war.

Other ministers followed this one, however, and Russian arrogance grew until it became objectionable to others than Japanese. The failure of Russia to carry out her pledges regarding the evacuation of Manchuria served admirably the purpose of the Japanese; but there were pretexts enough in Korea upon which to bring on the conflict so long prepared for, had this one not been at hand; the possession of Korea and the exertion of paramount influence in China being the stake at issue.

Third Change in Ten Years.-Thus it was that we were to see another great upheaval. In 1884 the haughty Chinese had driven the then insignificant Japanese from Korea, only to be most ignominiously 
driven out themselves after ten years by their no longer despised island neighbours, and now, after another ten-year period, the proud Russian was to be thrown into utter consternation and actually defeated in war by a race so contemned that they could not be taken seriously in their preparations for a conflict with so great an empire as that of the czar.

Russian Indifference.-This failure to appreciate the gravity of the situation was most astonishing. Russia's representatives seemed unable to realize what seemed apparent to others, that war was inevitable if conditions did not change; and when the subject was pressed upon him he declared that if Japan should actually commit any such grave mistake she would soon get enough of war. He took no measures to protect his ships at Chemulpo; he even dined out with a gay party the night of the day on which Japanese troops were landed, and on the next day he was a prisoner in his own legation while his ships were sunken wrecks at Chemulpo.

A few days later, on a cold gray morning with a pall of snow hanging over the city and falling gently upon us, I went with the other ministers to the railway station to bid adieu to our Russian colleague, who was departing with his family and staff and all the Russian residents, under a Japanese military escort, to a refuge on board a French ship at Chemulpo. He was not at all downcast apparently, and bade us au revoir but not good-bye. He was a brave and able man but his confidence was misplaced. 
Korea's Lost Opportunity.-This time Japan is taking no chances in Korea. The country is to be hers to exploit for herself. The Koreans are reaping the harvest of their own sowing through the twenty years during which they enjoyed more or less of independence. Instead of heeding good advice and clearing up their premises so no powerful neighbour would have an excuse for doing this for them, they played at all manner of silly pastimes. The king took upon himself the title of emperor in 1897 , and in 1902 he invited ambassadors from other lands to be present at a great anniversary that was to have been celebrated in honour of his forty years of rule. It was pitiful, but the kindly disposed man had his share of human frailties and yielded to the persuasions of his flattering courtiers, so that his government went from bad to worse until it became an easy prey to any one strong enough to go in and put things to rights. The verdict of war has left that task to Japan.

Our Own Position.-We may to-day regret our lost position in that land and the jeopardy in which many of our Asiatic interests are placed by virtue of the changed conditions, but it is late now to complain. True we have a treaty with Korea still, but it is reported that Japan wishes this set aside, at least to the extent of allowing of a customs union between the two countries, which would substitute for the nominal customs dues we now pay, the protective rates of Japan proper.

After her brilliant war with Russia, Japan is in no 
mood to accept any marked interference on our part in what she may consider as being her legitimate right to enjoy the fruits of her victory in her own "prearranged" manner. Our day for any such interference seems to have passed.

In the summer of 1903 it chanced to be my good fortune to make a trip through Manchuria, Siberia and Russia, on my way to America, returning to Korea by way of Japan. I had already reported upon the critical situation of affairs as I saw it, and explained how it seemed to me that a conflict was unavoidable. As I saw the great consumption of American products in Manchuria, it seemed to me that we were the ones most likely to profit by the expenditure of those hundreds of millions of Russian roubles in the pacification of that vast territory. It seemed also that we, of all people, were regarded by the Russians with the greatest favour and that we had the best opportunity of all for cultivating intimate trade relations with that vast empire, as yet almost undeveloped. As I saw the thousands of moujiks en route to the plains of Siberia and Manchuria, it was impressed upon me that these people could not be made into creditable artisans under at least two generations, if at all, while Russian institutions militated against the establishment of great manufacturing centres, since such must tend to become centres of social unrest.

While this seemed to be the case regarding Russia, Japan on the other hand was made up of a people quite our equals in a commercial and manufacturing 
sense, while they possessed the added advantage of cheap labour and practical immunity from grave labour troubles by virtue of their history of centuries of inbred habits of subordination. By encouraging Japan it seemed that we were egging her on to war, a war that would harm us probably more than it would Russia should Japan prove to be the victor. As to the result I put myself on record as of the opinion that Japan would succeed at sea and conquer Port Arthur, though I did not think the capture of that fortress would be the serious matter it proved to be, and I never supposed that Russia would capitulate so easily. However, I seem to have been about four years ahead of the times. Things in 1907 were not as they were in 1903, and whereas at the earlier date I was said to be "travelling out of his (my) province," I find now that many people seem to have secretly held similar ideas at that time, which they now express openly.

China the Real Objective.-Evidently, however, Japan now realizes that her future greatness depends upon her dominating China. Events succeeding her Russian victories indicated that she counted upon China's being so overawed by these successes over the latter's most dreaded neighbour as to induce her abjectly to accept Japanese guidance and eventually Japanese control. In other words, China, rather than Korea, became Japan's objective as success in increasing measure fell to her arms.

China seems to have acquiesced for a time, but she seems now to have regained her equanimity and to 
have resorted to her old-time tactics of delay and covert obstruction, while at the same time insisting upon the enjoyment of some of her rights.

Japan acts now regarding China's attitude, in a way made very familiar from watching her conduct in leading up to two previous wars,--those with China and Russia. War is an ugly word and one not pleasant to write in connection with present conditions in the Far East, but there is trouble of some kind brewing, and with England so tied up with Japan that she has to oppose the vested rights of her own people in supporting Japanese claims; with Russia prostrate for the time being; and with the Anglo-Japanese alliance securing Japan at least from molestation by any third power, a misstep on the part of China may well precipitate serious trouble upon the Middle Kingdom.

Incidentally any such trouble would doubtless result in one of the usual indemnities by which China invariably pays for her temerity in opposing a greater force, and this would serve Japan's purpose admirably at this time of depletion in her treasury. This would be a crime that should not be permitted; unfortunately we, with Germany, seem to be the only ones in position to speak for China, and speech in such case would have to have the backing of a strong fleet.

England's Position.-The strangest feature of this sudden rise of Japan is the position in which England must find herself. Her alliance of 1902 made the war with Russia possible. In order to protect 
her Indian frontier and perhaps to enable Japan to accede to the Russian terms at the time of the Portsmouth convention, she made the new and sweeping agreement with Japan of 1905, whereby she is obliged to come to the latter's assistance in case any third power makes war upon her. She probably never considered the possibility of our becoming involved in any such difficulty with Japan, since we had done almost as much for that country in connection with the war as had England herself. Germany was not so short-sighted, however, and by refraining from entering into any pact with Japan, such as France and even Russia have since entered into, she kept herself free to offer us her friendship should it become advisable. Later, England compounded her difficulties with Russia and even concluded an agreement which afforded the necessary protection for the Indian frontier, thus making the AngloJapanese alliance of 1905 not only unnecessary but an actual source of weakness.

While a war between America and Japan should, from the history of the relations between the two peoples, be one of the most improbable of possibilities, so much has been said upon the subject, and so many preventive measures have been reported as having been instituted, that it may be presumed some fire existed under all that cloud of smoke. The inability of raising funds in Paris, Berlin and London, is said to have been the great disperser of this ominous cloud; but there can be little doubt that England has done her share in calming any militant spirit that 
might compel her to risk a conflict with her " nearest of kin" and the consequent loss of contiguous territory.

England's Commercial Peril.-But aside from any such possible or probable war complications, England faces a grave problem in the usurpation of her control of the Asiatic trade by the rival she has conjured up in the Eastern seas, - a rival more clever than England herself in manufacturing lines, and one not to be despised in any commercial or financial undertaking. England is primarily a manufacturing nation and starvation and riot await the shutting down of her mills. So important is the China trade to these mills, particularly those engaged in cotton manufactures, that it has been asserted on good authority they cannot be kept running without this trade, the loss of which, therefore, means want and insurrection in the British Isles.

That Japan intends to control this trade is evident. That she is succeeding beyond expectations is apparent from her success in wresting from England the carrying trade in Asiatic waters.

Recently the chairman of the board of directors of the Peninsular and Oriental Steam Navigation Company, at a meeting in London, announced that there would be no dividend for the year just past because of the fact that the Japanese steamship lines had taken from them all their former great trade between India and the ports of China and Japan. This epochmaking paragraph seemed to pass through the American press with little or no editorial comment; 
but to one who has seen the important position held by the P. \& O. in Asia, where it has been one of the great British institutions, the announcement is pregnant with meaning and prophetic of greater changes yet to come.

America's Commercial Loss.-We stand to lose vastly by Japan's successes. Already she has made serious inroads upon our trans-Pacific carrying trade and may well be expected eventually to be in entire control of the commerce of the Pacific, if her progress continues. Our own export trade will suffer in all lines in which it is possible for Japan to compete; she is already shipping cotton goods to us, the reports for 1907 showing that while we only sent her manufactured cotton goods to the amount of $\$ 14,-$ 389 , she sold us goods of that character to the amount of $\$ 107,392$, and the balance of trade with us is heavily on her side, though she buys largely of our raw cotton. Our loss, however, will not be felt by our people as will that which faces England.

The Truce.-One of the most astute observers of Russo-Japanese relations before, during and since the war, has entitled his recent remarkable book, "The Truce in the Far East and its Aftermath." The title seems aptly chosen. The Island Empire of the Rising Sun is frequently torn and rent by terrible convulsions of nature. Advices from that country are to the effect that vast forces are feverishly engaged day and night in constructing all manner of warlike material; may this not portend an outbreak greater and more far-reaching than those 
natural phenomena to which the Japanese are more or less accustomed? If so the truce may be shattered. The alliance with England seems to make necessary some such convulsion during the seven years it still has to live, if it is to come at all, and yet this very alliance may well be used by England to prevent such a catastrophe,-in the interest of her own self-preservation; though if China is hectored into committing some act that may be taken by Japan as one of warlike aggression, it is difficult to see how Great Britain can avoid becoming entangled in the resulting clash, at least to the extent of attempting to see that other powers do not interfere in behalf of their own Chinese interests.

But even if China should escape, who knows but the little peninsula of Korea may not possibly witness another decennial overturn and pass under the guidance of yet another overlord? In 1884 China drove Japan from Korea. In 1894 Japan drove China from the peninsula. In 1904-5 Japan drove Russia from the entire Korean neighbourhood except in the vicinity of Vladivostock. In 1915 -. The blank will have to be filled later; may we be spared any military participation in events that may lead to any such change. 


$\frac{\text { nuye }}{\frac{125}{\text { net }}}$ 
SMITHSONIAN INSTITUTION LIBRARIES



